UNIVERSIDADE DE SÃO PAULO

FACULDADE DE ECONOMIA, ADMINISTRAÇÃO E CONTABILIDADE PROGRAMA DE PÓS-GRADUAÇÃO EM ECONOMIA

\title{
Caridade nos Clássicos Britânicos
}

Gabriel Godinho Ramos Ribeiro

Orientadora: Profa. Dra. Laura Valladão de Mattos

São Paulo

2017 
Prof. Dr. Marco Antonio Zago

Reitor da Universidade de São Paulo

Prof. Dr. Adalberto Américo Fischmann

Diretor da Faculdade de Economia, Administração e Contabilidade

Prof. Dr. Eduardo Amaral Haddad

Chefe do Departamento de Economia

Prof. Dr. Ariaster Baumgratz Chimeli

Coordenador do Programa de Pós-Graduação em Economia 


\section{GABRIEL GODINHO RAMOS RIBEIRO}

\section{Caridade nos Clássicos Britânicos}

Dissertação apresentada ao Departamento de

Economia da Faculdade de Economia, Administração

e Contabilidade da Universidade de São Paulo (FEA-

USP) como requisito parcial para obtenção do título de

Mestre em Ciências.

Versão Corrigida

São Paulo

2017 


\section{FICHA CATALOGRÁFICA}

Elaborada pela Seção de Processamento Técnico do SBD/FEA/USP

Ribeiro, Gabriel Godinho Ramos

Caridade nos clássicos britânicos / Gabriel Godinho Ramos Ribei-

ro. -- São Paulo, 2017.

$127 \mathrm{p}$.

Dissertação (Mestrado) - Universidade de São Paulo, 2017.

Orientador: Laura Valladão de Mattos.

1. História do pensamento econômico 2. Altruísmo 3. Filantropia I. Universidade de São Paulo. Faculdade de Economia, Administração e Contabilidade. II. Título.

CDD -330.09 


\section{RESUMO}

A dissertação aborda o tema da caridade privada e da assistência pública aos pobres em três autores do período clássico da Economia Política britânica: Adam Smith, Thomas Malthus e Jeremy Bentham. Argumenta-se que a questão está intimamente conectada à visão de natureza humana de cada um destes autores, bem como ao contexto histórico marcado pelas legislações conhecidas como "Leis dos Pobres" na Inglaterra. Smith aborda o assunto com ênfase em aspectos psicológicos e morais do homem, indicando que existem sérios obstáculos à realização da caridade direcionada aos mais necessitados, principalmente devido a menor propensão humana de simpatizar com o pobre, se comparada à propensão de simpatizar com pessoas mais afortunadas. Entretanto, para Smith, uma sociedade livre seria capaz de reduzir a pobreza extrema através da grande geração de riquezas consequente da divisão do trabalho e acumulação de capital, reduzindo a miséria e a necessidade da caridade. Na obra de Malthus, apresenta-se a visão de natureza humana partindo dos princípios da busca pela sobrevivência e reprodução, que teriam como consequência um aumento populacional sempre que a miséria fosse aliviada. A caridade, neste contexto malthusiano, deveria ser reservada a indivíduos merecedores, com "freio moral”, e as Leis dos Pobres deveriam ser abolidas. Já a abordagem de Bentham tem base em seu princípio da utilidade, bem como em sua perspectiva de que as motivações humanas são governadas pela busca do prazer e fuga da dor. A partir daí, Bentham evidencia a impossibilidade de que a caridade privada venha a suprir toda a demanda de caridade por indigentes. Para que se resolva o problema, o autor propõe o estabelecimento de uma instituição privada, a National Charity Company, que com subsídio público, se responsabilize pela eliminação da indigência através do encarceramento, auxílio e trabalho compulsório de todos indigentes capazes de realizá-lo. Defende-se que os três autores possuem abordagens diferenciadas, contudo, constata-se que são suas premissas comportamentais melhor compreendidas como a "natureza humana" em suas teorias - que fundamentam muitas de suas conclusões sobre os temas da caridade e Leis dos Pobres.

\section{Palavras-chave: História do Pensamento Econômico; Altruísmo; Filantropia}





\begin{abstract}
This dissertation adresses the theme of private charity and public relief to the poor by looking into the work of three authors from the classical period of Political Economy in Britain: Adam Smith, Thomas Malthus and Jeremy Bentham. The argument is that this matter is intimately linked to the conception of human nature of each author, as well as to the historic context related to the legislations known as the "Poor Laws" in England. Smith's approach is focused on psychological and moral aspects of men, indicating that there are serious obstacles to the offer of charity directed to people in need, mainly due to the lower propensity to sympathize with poor compared to the propensity to sympathize with more with people in better conditions. Nevertheless, to Smtih, a free society would be capable of reducing extreme poverty through the creation of wealth that results from the division of labour and capital accumulation, reducing misery and the need for charity. In Malthus' work, we find that his view of human nature starts from the principles of survival and reproduction, which have as a consequence a population increase whenever misery is alleviated. Charity, in this malthusian context, should be reserved to individuals that are deserving of receiving it, the ones with "moral restraint", and the Poor Laws should be abolished. Bentham's approach, on the other hand, starts from both his principle of utility and his perspective that human motivations are governed by the search of pleasure and avoidance of pain. From these ideas, Bentham argues that it is evident the impossibility of private charity being enough to supply for all the demand for charity from indigents. To solve the problem, the author proposes the establishment of a private institution, the National Charity Company, which would, with public subsidies, be responsible for the elimination of indigence through incarceration, relief and compulsory work of all capable indigents in need. It is argued that despite the different approaches from the three authors, in all of them it is possible to see that their behavioral premises (better comprehended as "human nature") are the basis of many conclusions on charity and Poor Laws.
\end{abstract}

\title{
Keywords: History of Economic Thought; Altruism; Philantropy
}





\section{AGRADECIMENTOS}

Agradeço a Deus.

Agradeço a minha família.

Agradeço a minha coordenadora, Prof ${ }^{a}$. Dra ${ }^{\mathrm{a}}$. Laura Valladão de Mattos, pela paciência e dedicação - principalmente nos momentos em que eu falhava em apresentar estas virtudes. E é claro, pelo conhecimento que adquiri com ela tanto por ocasião da orientação, como em seu curso de clássicos para a pós-graduação.

Agradeço aos professores que se dispuseram a fazer parte das bancas de qualificação e avalição de progresso, Prof. Dr. Jorge Soromenho e Prof ${ }^{a}$. Dr ${ }^{a}$. Ana Maria Bianchi, que naquelas ocasiões auxiliaram em muito, tanto na definição do escopo do trabalho, como em seu desenvolvimento.

Agradeço também aos membros da banca da defesa da dissertação, que além da Prof ${ }^{a}$. Dra . Ana Maria Bianchi, incluem o Prof. Dr. Mauricio Chalfin Coutinho e a Prof ${ }^{\mathrm{a}}$. Dr ${ }^{\mathrm{a}}$. Roberta Muramatsu, com a qual tive o prazer de me reencontrar em um ambiente acadêmico após sua orientação de minha monografia durante minha graduação no Mackenzie.

Agradeço ao Pinho e à Leka, pelo auxílio essencial nos mais diversos trâmites burocráticos e dúvidas sobre o programa.

Agradeço aos meus companheiros do mestrado (e alguns do doutorado), em especial Erick Baumgartner que me ajudou muito em momentos de grande dificuldade, Alex Hayato que me ajudou já milhares de vezes nas mais diversas situações, e Bruno Dammski, que me ajudou do modo mais inesperado possível. E é claro, muitos outros que me auxiliaram muito para que eu fosse capaz de superar as disciplinas obrigatórias do programa.

Um agradecimento especial também ao meu amigo Sérgio Mondrzejewski, que me ajudou não só no período em que cursou o início do curso comigo, mas posteriormente, se tornando um companheiro de confiança e um parceiro intelectual insubstituível.

E por último mas não menos importante, agradeço ao meu amigo, Thomas Paiva, por ter me ajudado demais, em troca de muito pouco. 



\section{SUMÁRIO}

1. INTRODUÇ̃̃ O..................................................................................................................13

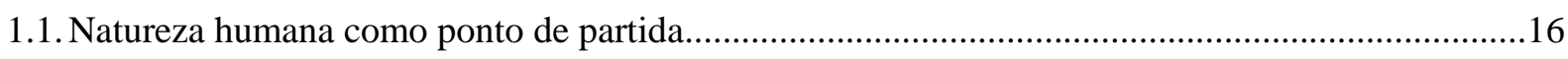

2. SMITH E O LONGO CAMINHO ENTRE ENTENDIMENTO E BENEVOLÊNCIA............19

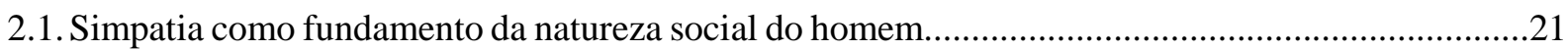

2.2. Para além da simpatia: inveja, gratidão e ressentimento...................................................................

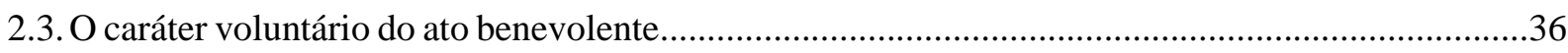

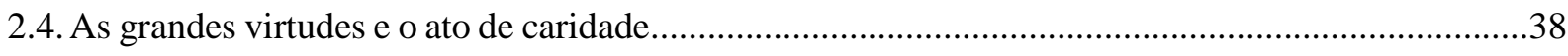

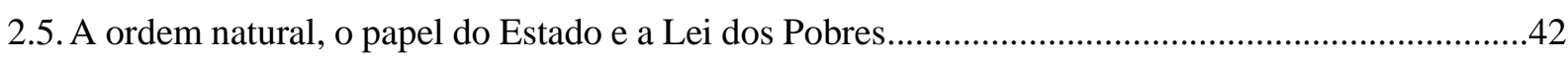

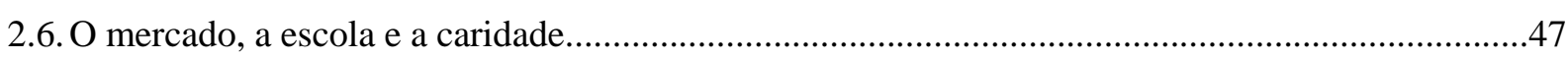

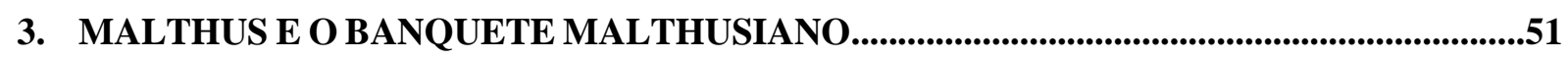

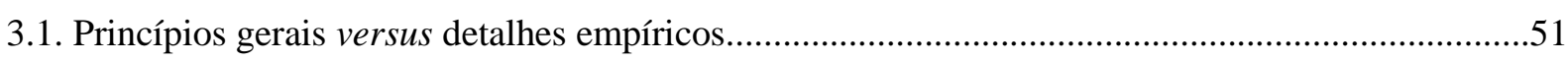

3.2. Desmembrando o "banquete da natureza" de Malthus.....................................................................53

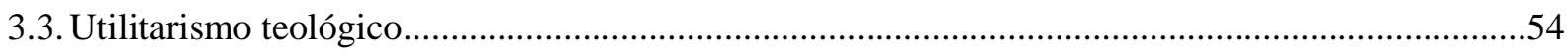

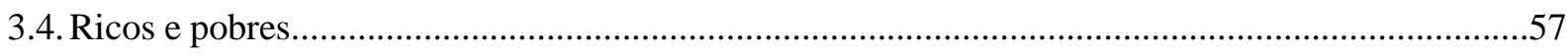

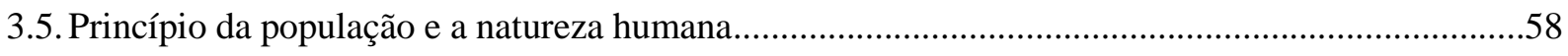

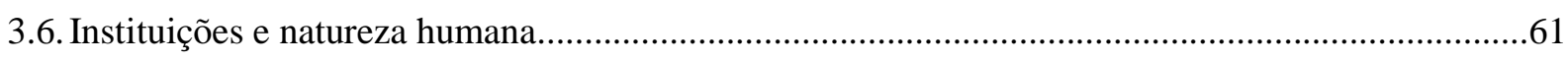

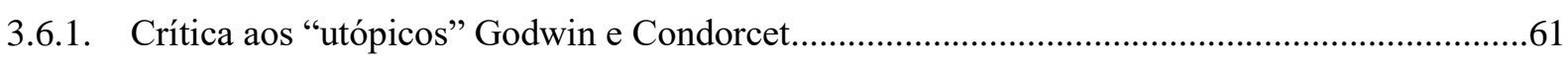

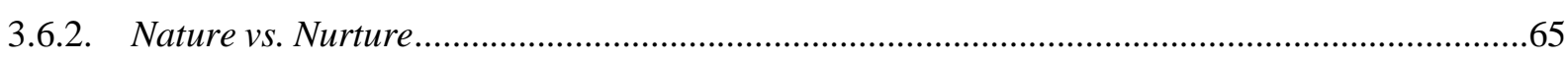

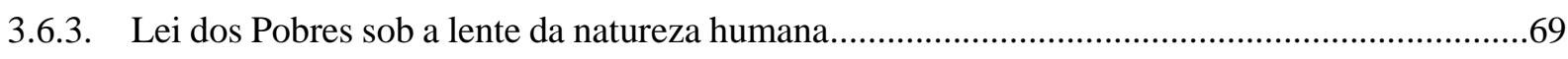

3.6.4. Condições institucionais para o desenvolvimento do freio moral.............................................72

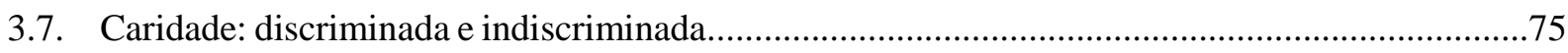

4. BENTHAM E O VALE ENTRE A TEORIA E A PRÁTICA................................................83

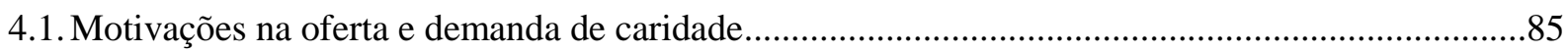

4.2. O princípio da utilidade e o papel do legislador.............................................................................95

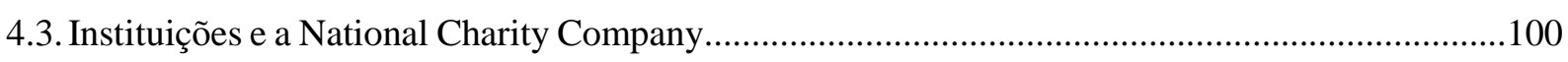

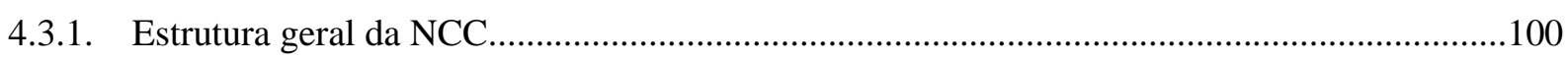

4.3.2. Liberalismo circunstancial e o objetivo de instituições como a NCC......................................106

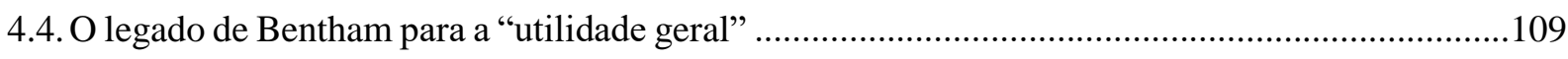

5. BREVE COMPARAÇÕES ENTRE SMITH, MALTHUS E BENTHAM.................................111

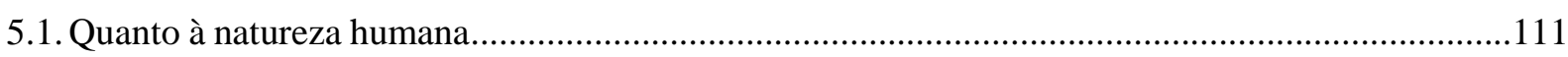

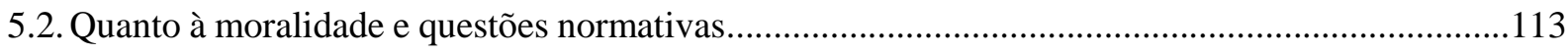

5.3. Quanto à oferta e demanda de caridade voluntária........................................................................115

5.4. Quanto ao papel do Estado no auxílio aos pobres.......................................................................117

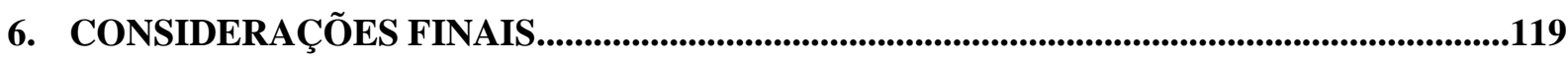

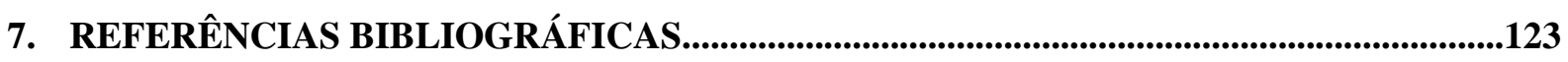





\section{INTRODUÇÃO}

O tema "caridade" não está entre os mais explorados dentro da teoria econômica. Embora a caridade seja um fenômeno que se relaciona diretamente com temas centrais da disciplina, como pobreza, distribuição de renda e o papel do Estado, na história do pensamento as obras mais relevantes são aquelas com uma ótica direcionada ao autointeresse e suas consequências. Existem, provavelmente, boas razões para isso. Ainda assim, embora o comportamento autointeressado tenha sido considerado chave para o entendimento econômico, é importante ressaltar que existem obras que tratam da caridade, inserindo-a dentro da teoria econômica. A proposta desta dissertação é explorar três importantes autores na história da economia que realizaram, em certa medida, esta tarefa: Adam Smith, Thomas Malthus e Jeremy Bentham ${ }^{1}$.

Os autores selecionados são "clássicos" das primeiras fases da economia moderna, situados entre a segunda metade do século XVIII e primeiros anos do século XIX. Todos escrevem também na Grã-Bretanha, berço de muitas das ideias econômicas no período consequência do pioneirismo do país na Revolução Industrial, cujo os primórdios se deram simultaneamente à publicação das principais obras que serão aqui analisadas. $\mathrm{O}$ pano de fundo histórico destas obras é a Inglaterra em rápida transformação econômica. Um exemplo de como tal contexto histórico influenciou profundamente os escritos econômicos no período é o debate sobre as Leis dos Pobres: um antigo conjunto de legislações que regulavam o trabalho dos mais pobres e responsabilizava o Estado Inglês a intervir na vida econômica destas pessoas através de auxílio e, frequentemente, da imposição de trabalho compulsório.

A história das Leis dos Pobres na Inglaterra tem seus primórdios na baixa idade média. Durante séculos, o auxílio aos indivíduos mais pobres estava muito conectado a atuação da Igreja e do sistema feudal. Apesar das restrições à liberdade do servo, "o feudalismo oferecia um sistema paternalista de segurança econômica" (QUIGLEY, 1996, p. 3). E, a Igreja, por meio de suas paróquias, exercia a responsabilidade de auxílio ao pobre por um "dever religioso" (QUIGLEY, 1996, p. 4). Ambas instituições, contudo, as organizações feudais e a Igreja Católica, estavam destinadas a entrar em declínio na Inglaterra. As primeiras por conta de

\footnotetext{
1 Não se pretende, neste trabalho, discutir filosoficamente as diferentes definições possíveis para os termos "altruísmo", "caridade", "benevolência", nem discutir se estes fenômenos são reais ou não. Tais questões são abordadas apenas na medida em que são necessárias para o entendimento da obra de cada autor, descrevendo, portanto, o posicionamento e definições utilizadas por cada um.
} 
transformações econômicas que levariam a concentração da miséria nas grandes cidades, e a segunda pela reforma protestante, que na Inglaterra se deu por meio de um rompimento entre o Estado Inglês e o Papa, estabelecendo o Anglicanismo no reino de Henrique VIII (QUIGLEY, 1996, p. 4-5).

Com as paróquias nas mãos do Estado e a gradual centralização do poder político, em conjunto com o processo de urbanização e dissolução das instituições feudais, estavam estabelecidas as condições para que o governo assumisse o papel de auxílio aos pobres, antes preponderantemente exercido pela Igreja. Isto é, pode-se afirmar que houve um processo de "secularização do auxílio aos pobres" (ELTON, 1953, p. 55). Os primeiros esquemas governamentais de auxílio datavam de 1531, e já diferenciavam pobres capazes e incapazes de trabalhar, bem como já instituía o trabalho compulsório para os capazes (QUIGLEY, 1996, p. 11-13). Mas foi em 1597 e 1601 que atos com marcos fundamentais do que viriam ser as Leis dos Pobres foram estabelecidos: a responsabilidade local dos agentes do governo nas atividades de auxílio; a remoção dos pobres fora de suas paróquias nativas; e a responsabilidade da família do pobre como prioritária (QUIGLEY, 1996, p. 16). Os dois primeiros princípios estão relacionados entre si, cada paróquia era responsável pelos seus próprios pobres - teoricamente evitando que paróquias específicas fossem sobrecarregadas. Os Settlement Acts de 1662 reforçavam este intuito, dando poder às autoridades locais para remover pobres de suas paróquias se estes houvessem chegado recentemente. No início do século XVIII, o custo da responsabilidade do Estado começava a se tornar um peso expressivo, e, para amenizar este problema, em 1722, foram criadas as chamadas workouses (casas de trabalho), afim de reduzir custos e aumentar a eficiência do trabalho do pobre, de modo que, idealmente, este pudesse pagar pelo seu próprio sustento. $\mathrm{O}$ ato de 1722, era um reconhecimento de que o auxílio fora da casa de trabalho (outdoor relief), era não apenas muito custoso, mas também "fácil" demais, ou seja, não criava desincentivos à busca de auxílio (QUIGLEY, 1996, p. 21-23). Entretanto, entre 1722 e o final do século, a prática do outdoor relief gradualmente retornou, e, em 1795 , notava-se a presença significativa de um sistema de auxílio mais generoso conhecido como "Speenhamland". Na prática, o sistema garantia uma renda mínima, com complemento do salário por parte das autoridades locais. Isto levaria aos capitalistas a evitarem pagar salários elevados, na expectativa de que o Estado complementaria a renda do trabalhador (QUIGLEY, 1996, p. 23-25). É apenas neste período, no final do século XVIII, que a Inglaterra começa a se industrializar.

Assim, a maior parte do desenvolvimento das Leis dos Pobres se dava ainda em um período pré-industrial na Inglaterra. Apesar da urbanização gradual e do desenvolvimento de 
uma sociedade comercial, em meados do século XVIII, o país ainda não havia passado pela grande ruptura econômica que a Revolução Industrial ocasionaria. Smith escreve neste período, ainda anterior à industrialização, a sua Theory of Moral Sentiments, que tem sua primeira edição publicada em 1759. Antes do lançamento de seu livro mais famoso (The Wealth of Nations de 1776), Smith construía ali os alicerces de sua teoria sobre o homem em si, suas paixões, sua moral, seu caráter, enfim, sua psicologia em sociedade. A profundidade do conteúdo da obra é mais que suficiente para explorar o tema da caridade sob o ponto de vista de Smith. Mas o período em que ele escreve não apresenta as condições de "pauperização" em massa, que caracterizaria a virada do século XVIII para o XIX na Inglaterra. As transformações que Smith notaria estão mais relacionadas a redução do papel da Igreja, e sua visão do homem carrega elementos que não são frequentemente relacionados ao capitalismo industrial, como o destaque à virtude da benevolência, como veremos mais adiante.

O tom nas obras de Malthus e Bentham é completamente distinto ao de Smith. Ambos escrevem no final do século XVIII e início do século XIX, no momento em que a industrialização começa a se acelerar na Inglaterra, ao mesmo tempo em que há uma percepção geral de que as Leis dos Pobres teriam falhado em suas prerrogativas. Os sistemas mais flexíveis de auxílio (como o esquema de Speenhamland) que viriam a substituir as casas de trabalho, pareciam apenas agravar o problema, levando a disseminação da indigência, com graves custos sociais. Ambos autores foram, neste contexto, profundamente críticos as Leis dos Pobres, e trataram do assunto com uma especificidade maior que Smith. Entretanto, apesar de compartilharem o mesmo contexto histórico, Malthus e Bentham propuseram soluções distintas à questão da miséria ou indigência. Enquanto Malthus prefere eliminar o papel do Estado e abolir as Leis dos Pobres, propondo em seu Essay on Population (primeira edição publicada em 1798, e última edição de 1826) que a caridade deve ser voluntária e privada, Bentham propõe a substituição da Lei dos Pobres por um esquema muito mais ambicioso, a National Charity Company, proposta em seus Tracts On The Poor Laws (1797), com forte intervenção do Estado em conjunto com interesses privados para realizar auxílio e organizar o trabalho dos que passam necessidade.

O objetivo deste trabalho, contudo, não é realizar uma revisão histórica do período em si, mas sim das ideias de três autores no período, com um foco na questão da caridade e Lei dos Pobres. Entre os assuntos que serão tratados neste contexto é possível destacar as motivações individuais para o exercício voluntário da caridade, isto é, o que faz (ou impede) que uma pessoa exerça a caridade para aliviar o sofrimento do próximo? Tal pergunta se conecta diretamente com a discussão daquilo que denominaremos de "oferta de caridade", isto é, o quanto uma 
comunidade oferece, voluntariamente, para o auxílio aos pobres. Seria esta oferta suficiente? Esta resposta, por sua vez, depende da discussão sobre "demanda de caridade", ou seja, o quanto os indivíduos em pobreza extrema precisam para manter-se em uma condição econômica minimamente adequada. Dependendo das respostas do quanto oferta-se voluntariamente e do quanto demanda-se de caridade, seria possível responder também até que ponto a caridade privada é necessária - isto é - uma vez que pessoas necessitam de auxílio, até que ponto é um dever moral ou uma virtude o exercício da benevolência? Sendo um dever, haveria papel para o Estado garantir que o auxílio seja realizado, mesmo que isso signifique excluir o caráter voluntário do ato de caridade? São estas algumas das perguntas que foram buscadas nas obras dos três autores. É bem interessante que, ao tratar destes temas, as premissas dos autores se relacionam com aspectos mais amplos de suas obras, em especial, noções comportamentais, que podemos entender como "natureza humana", ampliando substancialmente o escopo do trabalho.

\subsection{Natureza humana como ponto de partida}

O ponto de partida deste trabalho é a concepção de natureza humana que cada autor apresenta. A razão para esta escolha é que é através do entendimento de como o homem age, pensa, sente, em contextos sociais, que é possível avaliar a propensão e a maneira de se realizar caridade ou pedir auxílio. Embora a discussão dos elementos da natureza humana seja complexa e possa ser considerada um verdadeiro campo minado de dificuldades semânticas, trata-se de um ponto de partida bastante adequado para o tema da caridade. Nos três autores, são as ideias que constituem a natureza humana que fundamentam conclusões quanto ao tema. Há, certamente, diferenças significativas nas concepções que esses autores apresentam sobre o comportamento do homem - no entanto, todos concordam que existe natureza humana, isto é, existem comportamentos que são inatos ao homem. Isto não significa que tais comportamentos nunca sejam moldáveis pelo ambiente, ou que não exista variabilidade entre diferentes pessoas, ou ainda que o próprio homem não possa lutar contra sua natureza. Mas, para eles, há um componente inato às tendências ou leis psicológicas. Veremos que estas questões, quando abordadas, são tratadas de modo diferente por cada autor. Para Smith, por exemplo, a simpatia é presente em todos homens e o autocomando permite que a vontade do indivíduo supere seus próprios instintos. Para Malthus, o homem possui instintos fortíssimos de reprodução e 
sobrevivência, e é impossível que instituições anulem estes impulsos. Para Bentham, o comportamento do indivíduo é, invariavelmente, direcionado pela busca do próprio prazer e dor, mas as instituições são importantes para manipular estes interesses egoístas em prol da utilidade geral. Sejam quais forem as semelhanças e contrastes em suas concepções do homem, para todos eles há um elemento natural no comportamento humano, e este elemento é central para a análise das questões relacionadas à caridade e Leis dos Pobres. As motivações para caridade que cada indivíduo em sociedade possui, bem como os argumentos quanto ao papel (ou ausência de papel) do Estado no auxílio aos pobres, surgem com base nestas premissas comportamentais e morais.

Ao longo da dissertação, uma ordem aproximada para a análise de suas ideias foi adotada: a partir da concepção de natureza humana de cada um, procurou-se extrair uma teoria psicológica relacionada à benevolência. Em seguida, articular esta concepção psicológica com o tipo de moralidade defendido por cada autor. E, por fim, analisar como a caridade privada, o auxílio público aos pobres e outras instituições relacionadas à caridade podem ser compreendidas nas suas respectivas obras, à luz destas noções psicológicas e morais. 


\section{SMITH E A LONGO CAMINHO ENTRE O ENTENDIMENTO E A BENEVOLÊNCIA}

O livro The Theory of Moral Sentiments ${ }^{2}$, publicado em 1759, foi escolhido como o primeiro texto a ser analisado. Nessa obra, Smith delineia com profundidade uma série de características essenciais do comportamento e da percepção moral do homem. Tal descrição da natureza humana é um bom ponto de partida à uma discussão sobre caridade e Lei dos Pobres justamente por que, a partir dos sistemas desenvolvidos por Smith na TMS, é possível chegar a uma teoria dos pré-requisitos à caridade. Relacionada a esta questão, é possível também entender como a ética de Smith se articula com a presença da pobreza e qual a atitude adequada de indivíduos e do Estado frente a este fenômeno econômico e social. Tudo isso, contudo, Smith realiza em um contexto histórico relativamente distinto daquele em que se encontram os demais autores que serão tratados posteriormente neste trabalho (Malthus e Bentham, ambos escrevendo em torno da virada do século XVIII para o século XIX). Como já foi mencionado, Smith escreve a TMS antes do início da Revolução Industrial propriamente dita, e a Wealth of Nations ${ }^{3}$, ainda muito nos primórdios do processo de industrialização na Inglaterra. $\mathrm{O}$ aprofundamento da urbanização industrial, e o crescimento populacional do período, combinados com possíveis efeitos perversos que o relaxamento das Leis dos Pobres causaria, ainda não eram questões prioritárias para Smith. São poucas as referências em sua obra às Leis dos Pobres, e, essencialmente, não é discutida a questão central do auxílio público em si. Ainda assim, tamanha é a amplitude da TMS (e da $\mathrm{WN}$ ), que mesmo sem tratar especificamente dos temas de caridade e Lei dos Pobres, Smith fornece uma explicação relevante ao tema, que não pode ser ignorada tanto pela riqueza de suas ideias, como pela influência que elas posteriormente exerceriam (em boa parte por conta da própria fama que Smith adquire como "pai” da Economia Política).

Superficialmente, o fenômeno da caridade pode parecer relativamente simples, um ato motivado pelo desejo de melhorar a condição do próximo. Entretanto, não é bem assim que atos de benevolência são explicados por Smith. O que seria necessário para que uma pessoa saia de sua própria estrada e ajude o outro? A explicação passa, como foi mencionado, pela exploração da concepção da natureza humana exposta na TMS, que se inicia com o fenômeno da "simpatia", uma palavra que se aproxima do que hoje denominamos de "empatia" - colocar-

\footnotetext{
2 Doravante "TMS".

3 Doravante "WN".
} 
se na posição do outro e sentir, em parte, o que o outro sente. Este sentimento estaria na base de uma série de outras paixões sociais, incluindo paixões que motivam nossos atos benevolentes. Nesse contexto, a caridade deixa de ser um fenômeno de simples, fácil de ser realizado e explicado. Afinal, o estado psicológico que um indivíduo precisaria se encontrar para que tais paixões benevolentes se manifestem é um estado raro. Segundo Smith, é bastante difícil que o homem venha a simpatizar com outros em condição de miséria - nosso instinto inicial é de afastamento, e, muitas vezes, é necessário considerável esforço para encontrar a compaixão suficiente que motive a caridade. Em outros casos, o problema é ainda mais fundamental, não simpatizamos com aqueles que sofrem meramente por não compreendermos as razões de seus sofrimentos, ou, o que também é possível, por considerarmos que o sofrimento destas pessoas mais pobres é condizente com suas falhas pessoais, e reprovamos suas lamentações.

A teoria sobre caridade daí derivada, e que será aqui apresentada, segue um caminho complicado, longo, em que a simpatia é um dos elos condicionantes para conectar o indivíduo que demanda e o indivíduo que oferta caridade. O primeiro elo desta cadeia não é a simpatia em si (apesar de ser um importante elo), mas o "entendimento". Em grandes linhas a teoria poderia ser resumida no seguinte caminho entre entendimento e benevolência:

O entendimento de uma situação alheia é condição necessária, mas não suficiente para a sua aprovação. Esta requer também a percepção de que a paixão manifestada por quem a sofre seja "apropriada", isto é, adequada à situação. A aprovação, por sua vez, é condição necessária, mas não suficiente para que a simpatia se manifeste. A simpatia, elo importante do caminho até a benevolência, requer também que as paixões alheias sejam concebíveis ao espectador, pois se forem muito intensas ou abstratas, há pouca chance de que os sentimentos possam ser transmitidos de um indivíduo a outro. E enfim, na grande maioria dos casos, a simpatia é condição necessária, mas não suficiente, para a benevolência. Esta requer também o exercício da mais importante das virtudes humanas segundo Smith: o autocomando. Caridade, por sua vez, seria uma manifestação específica da virtude da benevolência.

Embora a simpatia não seja, em si, o único condicionante para um ato de caridade, ela possui um papel especial no sistema de Smith - ela é o pilar que sustenta o que poderia ser chamado de "natureza social" do homem, e, assim, quase toda TMS depende do fenômeno da simpatia ou se articula com ele. A explicação de cada parte do caminho acima demanda o estudo resumido desta visão de natureza humana, o que é realizado nas duas próximas seções (com atenção especial aos tópicos referentes à benevolência). Em seguida apresenta-se um estudo da própria benevolência como virtude, bem como do conceito de virtude em Smith e suas 
implicações ao tema da caridade. Após essas seções que concernem a visão de Smith sobre a natureza humana, abordam-se questões relacionadas ao efeito que as instituições sociais poderiam (ou não) exercer sobre essa disposição a praticar o ato de caridade, e, por fim, é apresentada como a Lei dos Pobres se insere neste contexto para Smith. Para estudar estes pontos, a consulta à TMS é prioritária, ainda que trechos específicos de outras obras de Smith tenham ocasionalmente fornecido esclarecimentos necessários. Ao longo da exposição, ficarão evidentes as consequências econômicas da visão de Smith quanto à natureza humana em relação à caridade, ainda que na TMS não fosse a economia sua preocupação essencial.

\subsection{Simpatia como fundamento da natureza social do homem}

Frequentemente entende-se que as ideias expostas por Smith na sua obra mais famosa (WN) remetem ao comportamento auto interessado do homem, destacado como componente esperado de uma ordem espontânea na economia. Através de um "sistema óbvio e simples de liberdade natural" (SMITH, 1979 [1776], p. 687), sem restrições arbitrárias e com o elemento decisivo da justiça, seria possível aproveitar ao máximo os benefícios inesperados que o autointeresse fornece. Seria, contudo, um erro assumir que a visão de Smith quanto à natureza humana se resume à consideração própria do indivíduo. O oposto parece ser verdade, visto que, na construção de sua interpretação do homem, Smith insere a simpatia como fenômeno essencial $^{4}$. Ou seja, é justamente da possibilidade de consideração das circunstâncias alheias que o homem desenvolve muitas de suas paixões. O primeiro trecho da TMS parece destacar a importância deste forte interesse direcionado ao destino do próximo:

How selfish soever man may be supposed, there are evidently some principles in his nature, which interest him in the fortune of others, and render their happiness necessary to him, though he derives nothing from it except the pleasure of seeing it (SMITH, 1984 [1759], p. 9).

Esta inquietação com o destino do próximo, por sua vez, surgiria justamente da capacidade de colocar-se em seu lugar e, de certa forma, sentir o que o outro sente. É dessa maneira que Smith define o conceito de simpatia, seja esta uma paixão negativa ou positiva:

\footnotetext{
${ }^{4}$ Em realidade, o autointeresse surge no sistema de Smith como uma consequência de um conjunto mais complexo de mecanismos naturais, básicos, em especial a simpatia, como será exposto mais adiante.
} 
Pity and compassion are words appropriated to signify our fellow-feeling with the sorrow of others. Sympathy, though its meaning was, perhaps, originally the same, may now, however, without much impropriety, be made use of to denote our fellow-feeling with any passion whatever (SMITH, 1984 [1759], p. 10).

Imaginar-se-ia, portanto, que aliviar o sofrimento alheio fosse do interesse de todos, afinal a simpatia tornaria nossa felicidade contingente a dos demais. Contudo, na medida em que Smith convence o leitor com exemplos que ilustram o funcionamento da simpatia na prática, fica claro que um entendimento superficial de simpatia pode ser facilmente errôneo. Não é a paixão alheia, por si só, que engaja o observador em absorver parte dela - é a situação, isto é, a capacidade de se colocar no lugar do outro, que permite a emergência da simpatia (SMITH, 1984 [1759], p. 12). Ela é um elemento relacionado à faculdade humana de imaginar, e, portanto, entender a condição alheia. Na medida em que a compreensão desta situação alheia é bem sucedida, e quanto maior vivacidade da imaginação, maior será a paixão que a simpatia pode transmitir ao observador. Ao mesmo tempo, na medida em que esta compreensão é insuficiente ou inexistente, menor é a chance de que a simpatia tenha efeito sobre o observador.

Como poderia ser então que, apesar da existência da simpatia, Smith confie tanto na predominância do autointeresse como fundamento comportamental na $\mathrm{WN}^{5}$ ? Esta questão se conecta ao conhecido "Das Adam Smith problem" - a suposta contradição entre a simpatia benevolente que seria a base da TMS com o autointeresse na WN. Este paradoxo, contudo, surge de uma interpretação equivocada do conceito de simpatia, a de que esta implica ou é equivalente à benevolência, o que pode ser descartado através de uma leitura cuidadosa. Enquanto é verdade que a simpatia é frequentemente uma condição necessária para a virtude da benevolência (assim como é basilar para todas as demais virtudes delineadas por Smith), ela não é uma condição suficiente. Uma compreensão mais profunda do conceito de simpatia exemplificado abundantemente por Smith no primeiro capítulo da TMS indica que parece adequada a rejeição do Das Adam Smith Problem. Simpatia, afinal, demanda o entendimento da condição alheia, além de uma aprovação do espectador com os sentimentos, pensamentos e paixões da pessoa observada, exigindo, portanto, imaginação e possivelmente esforço por parte

\footnotetext{
${ }^{5}$ Confiança esta que pode ser exemplificada com o famoso trecho da WN: "It is not from the benevolence of the butcher, the brewer, or the baker, that we expect our dinner, but from their regard to their own interest" (SMITH, 1979 [1776], p. 26-28).

${ }^{6}$ Khalil (2006) resume o dilema da seguinte forma: "The first shot challenging Adam Smith the hedgehog is the controversy surrounding the well-known 'Das Adam Smith Problem' (...). This problem is about the reconciliation of diverse incentives: how to reconcile self-interest, which is the focus of WN, and benevolence, which is the concern of TMS? Put differently, can one explain self-interest - regarded here as non-myopic - if one thinks that sympathy is the operative mechanism in human behavior? Clearly, one can explain benevolence with sympathy. But this is not clearly the case with self-interest" (KHALIL, 2006, p. 6).
} 
do observador para que ela se estabeleça. Khalil (2006), explica esta importante diferenciação com o seguinte trecho:

Definition 1: sympathy $=$ benevolence.

Given the definition, it was very easy to declare 'Das Adam Smith Problem'. But the problem vanishes if we use the following definition:

Definition 2: sympathy = understanding (KHALIL, 2006, p. 6).

Enquanto a própria definição de simpatia como entendimento apresentada por Khalil ainda é uma simplificação, ela se aproxima muito mais da explicação dada por Smith do que a presunção automática de que simpatia e benevolência são equivalentes. Na mesma linha, Raphael e Macfie (1987) incisivamente rejeitam o suposto paradoxo entre a TMS e a WN:

The so-called 'Adam Smith problem' was a pseudo-problem based on ignorance and misunderstanding. Anybody who reads TMS, first in one of the earlier editions and then in edition 6, will not have the slightest inclination to be puzzled that the same man wrote his book and WN (RAPHAEL e MACFIE, 1987, p. 20)

A presença de simpatia, ademais, não é contraditória ao autointeresse no sistema de Smith, pelo contrário - justamente por estarmos mais familiarizados com nossa própria condição (e, portanto, sermos capazes de entende-la e aprova-la) do que a do outro, é natural que atentemos mais as nossas próprias paixões que as dos outros. Khalil (2001) entende esta noção como uma "simpatia com seus próprios sentimentos", que é mais facilmente alcançada e induz a uma tendência geral ao comportamento auto interessado (KHALIL, 2001, p. 423) ${ }^{7}$. Em outras palavras, nessa interpretação pode-se entender que o mesmo caminho que leva à simpatia (que é definida, em geral, como um fenômeno direcionado às paixões alheias), também explica o autointeresse como via de regra para o comportamento humano: o entendimento e aprovação das próprias paixões é dado.

Já o comportamento humano que é sinceramente dependente da condição alheia surge da tentativa (ou propensão) de simpatizar com o próximo. Esta propensão, pode ser interpretada como o elo que conecta o indivíduo à sociedade, e, assim, permite que surja uma capacidade de

\footnotetext{
${ }^{7}$ Esta interpretação, contudo, não é coerente à definição de simpatia que Smith oferece ao leitor. Essencialmente, simpatia é necessariamente um fenômeno que decorre de uma interação social, não podendo ocorrer isoladamente. Ainda assim, a interpretação de Khalil possui mérito: a intenção é destacar o quanto o entendimento e aprovação são necessários para simpatia, e, da mesma forma que nos interessamos mais intensamente pela condição de uma paixão alheia que compreendemos e aprovamos, e menos intensamente (ou até mesmo não nos interessamos) por paixões que não compreendemos, faz sentido imaginar que, entre todas as pessoas das quais estamos dispostas a nos simpatizar, "nós mesmos" seria o extremo em que a "simpatia" (ou mais precisamente, o interesse e absorção das paixões sentidas) é garantida - é um caso tão particular, contudo, e com a essencial característica de não haver interação social, que a definição de Smith não abarca uma "simpatia para si próprio", como argumenta Khalil.
} 
julgamento das ações, paixões e pensamentos do outro. Ao observar um comportamento de um outro indivíduo, o espectador pode aprovar ou reprovar tal comportamento, seja ele qual for, e, para assim fazê-lo, é necessário tentar se colocar na posição alheia ${ }^{8}$. Uma hipotética ausência dessa propensão natural a buscar simpatizar e obter a simpatia das pessoas ao seu redor resultaria em uma sociedade atomizada, em que não há razão para esperar qualquer conexão psicológica real entre indivíduos, não impedindo que estes observem os demais como meros objetos ao seu redor. Não é exagero afirmar, portanto, que a simpatia é o fundamento da natureza social do homem, dentro do sistema de Smith.

Antes de analisar a simpatia em si, contudo, um passo atrás é necessário. Quais seriam os condicionantes à simpatia? Como já mencionado, o primeiro passo é o entendimento da situação que o outro se encontra. Entender no sentido de compreender o contexto e o processo psicológico do indivíduo que realiza a ação observada. Infinitos exemplos poderiam ser dados. Utilizando um dado pelo próprio Smith: o sofrimento e protestos expressos por Hipólito 9 durante sua tortura nos incita simpatia justamente por entendermos o contexto, que incluí tanto a inocência do crime pelo qual ele foi acusado, bem como a consequência prevista de sua punição, que será a morte (SMITH, 1984 [1759], p.30). Ou seja, primeiramente, somos capazes de entender que a tortura em questão e previsão da própria morte gera sofrimento intenso. Se, por alguma razão, fossemos incapazes de compreender a paixão alheia, não seríamos capazes nem mesmo de julgar se esta é apropriada ou não, muito menos de simpatizar. Por exemplo, é impossível simpatizar com alguém que se demonstra furioso com as pessoas a seu redor se não sabemos qual o motivo de sua raiva (SMITH, 1984 [1759], p. 11). Um outro exemplo dado por Smith, que explica esta pouca tendência a induzir simpatia sem entendimento, seria a exposição de um sofrimento exagerado por causa de uma mera "cólica" (SMTIH, 1984 [1759], p. 30) poucas dores seriam tão intensas, mas o entendimento de que uma recuperação e desaparecimento da dor em um futuro próximo é certo colocaria o espectador em confusão quanto à incapacidade de quem a sofre de aguentar as dores. Adicionalmente, um indivíduo que nunca sentiu uma cólica, nem possui outra forma de compreender a intensidade e características destas dores, é essencialmente incapaz de entender as manifestações de quem as sentem. Assim, o próprio entendimento da situação do próximo possui a condição de conseguir se colocar no

\footnotetext{
${ }^{8}$ Poderia-se esquematizar a ideia da seguinte forma: a tentativa de simpatizar e buscar simpatia é um instinto humano. É a partir deste aspecto da natureza humana que se busca o entendimento da condição alheia (ou se busca explicar ao espectador sua própria condição). Dada esta tentativa, busca-se o entendimento, dado o entendimento, busca-se a aprovação, dada a aprovação, busca-se a simpatia.

${ }^{9}$ A história é baseada em uma tragédia grega em que Hipólito é injustamente acusado de assassinar sua própria madrasta (BATES, 1903, p. 188-192).
} 
lugar do próximo. Indivíduos com características e experiências similares, possuem este primeiro passo, o entendimento, praticamente dado. Por esta razão pode-se afirmar que para “para o altruísmo, um grau de familiaridade é crucial” (KHALIL, p. 423, 2001), uma vez que o entendimento é o primeiro passo do caminho até a benevolência. É neste sentido, que Smith destaca também que o grau de familiaridade com a condição do outro se manifesta mais claramente na nossa propensão de simpatizar com parentes próximos do que com parentes mais distantes, e mais com estes do que com completos desconhecidos (SMITH, 1984 [1759], p. 219-220). Esta observação é relevante quando conectada com a visão mais "biológica" da natureza humana, que será mais discutida posteriormente na seção dedicada à Malthus ${ }^{10}$.

Contudo, a noção de familiaridade que ajuda o processo de entendimento da condição alheia não é resumida puramente em termos de graus de parentesco. Entender o sofrimento de um vizinho que perdeu sua casa devido a um desastre natural é muito mais fácil que entender o sofrimento de alguém a milhares de quilômetros que sofreu da mesma desventura - o contexto é distante demais, não se sabe o quanto a casa era valorizada pelo indivíduo, não se sabe o esforço que teria sido realizado para obtê-la, não se conhece nem ao menos o caráter daquele indivíduo e nem mesmo os detalhes de como a casa foi destruída, pois não foi observado de perto o desastre. É bastante difícil inferir corretamente qualquer uma destas informações, entre várias outras necessárias para o entendimento intuitivo do contexto em questão.

Voltando ao exemplo de Hipólito, a aprovação dos protestos do personagem, por sua vez, representa um passo além do entendimento de sua condição. Aprovamos os protestos e concordamos com a propriedade do sofrimento durante sua a tortura não só por que ele irá morrer, nem por que conseguimos imaginar o quão horrível deve ser passar por tal experiência. Apesar de ser necessário compreender estes aspectos, aprovamos a propriedade dos protestos (e rejeitamos sua punição) justamente por conhecermos sua inocência, previamente exposta ao espectador. Se fosse o caso de que a culpa de Hipólito fosse verdadeira, possivelmente reprovaríamos seus protestos (e talvez aprovaríamos sua punição). Não haveria possibilidade de simpatia neste caso (em que reprovamos seus protestos). Seria possível simpatizar sabendo

\footnotetext{
${ }^{10}$ Em maior detalhe, a posição de Smith poderia ser interpretada sob o ponto de vista biológico da seguinte forma: "a noção de Smith de proximidade social é conceitualmente análoga à proximidade genética em um nível biológico" (KHALIL, p. 424, 2001). Outro trecho da TMS que reforça esta interpretação é: "A jealous husband, indeed, notwithstanding the moral connection, notwithstanding the child's having been educated in his own house, often regards, with hatred and aversion, that unhappy child which he supposes to be the offspring of his wife's infidelity" (SMITH, p. 223, 1984 [1759). É possível dizer que compreendidas atualmente as consequências evolucionárias de um altruísmo que seleciona com base na proximidade genética, percebe-se que o argumento de Smith quanto à benevolência neste caso, assim como os argumentos de Malthus, seriam uma constatação de fenômenos sociobiológicos os quais a ciência ainda não havia demonstrado no período em que as obras destes autores foram escritas.
} 
que ele é culpado? Sim, mas apenas se aprovarmos seus protestos por julgarmos a punição inapropriada, excessiva (e, portanto, seus protestos, apropriados).

Todo este processo que envolve tanto o entendimento da situação como a aprovação das paixões manifestadas através de comportamentos, é resumido por Heilbroner (1986) da seguinte forma:

(...) our sympathy depends on our ability to approve of another's behavior because it is appropriate to the situation. Until we understand the context of another's behavior we cannot know whether our own emotional response will be one of positive sympathy or negative revulsion, of approval or disgust (HEILBRONER, 1986, p. 58, itálicos adicionados).

Como se percebe, os primeiros obstáculos para alcançar a "simpatia positiva" são grandes. Isto se tornaria mais difícil ainda devido ao fato de que a recíproca (aprovação implica em simpatia) não é sempre verdadeira, ou seja, mesmo aprovando as paixões não há garantia de simpatia. Muitas vezes, percebemos que deveríamos simpatizar com uma paixão alheia, ou seja, aprovamos a paixão, mas não conseguimos simpatizar de fato:

\begin{abstract}
A stranger passes by us in the street with all the marks of the deepest affliction; and we are immediately told that he has just received the news of the death of his father. It is impossible that, in this case, we should not approve of his grief. Yet it may often happen, without any defect of humanity on our part, that, so far from entering into the violence of his sorrow, we should scarce conceive the first movements of concern upon his account. Both he and his father, perhaps, are entirely unknown to us, or we happen to be employed about other things, and do not take time to picture out in our imagination the different circumstances of distress which must occur to him (SMITH, 1984 [1759], p. 17-18).
\end{abstract}

A ausência de simpatia neste caso ocorre devido à dificuldade de imaginar tão intensa perda, e, apesar do espectador compreender o sofrimento do estranho que perdeu o pai e entender a razão pela qual ele sofre, a intensidade da perda de um familiar não é facilmente transmitida - principalmente, como Smith observou, se pouco esforço para simpatizar for realizado. Esta frequente ausência de simpatia no caso de paixões negativas muito intensas é compreendida pelo menos duas considerações forem realizadas: (i) tamanho é o sofrimento alheio, que é de difícil para o observador imaginar o que o outro está passando, isto é, a emoção pode ser tão intensa que um estranhamento pode ser uma reação mais natural que a simpatia; (ii) há um incentivo em evitar a simpatia, uma vez que ao se colocar no lugar do outro, o observador absorve (em menor grau), parte daquele sofrimento.

É neste contexto que pode-se começar a discutir as circunstâncias necessárias para simpatizar com alguém em condições de pobreza. Para Smith, além dos passos do entendimento e da aprovação que todo sentimento simpático demanda, a pobreza, ao transmitir paixões 
negativas relacionadas à privação material, tende mais a afastar emocionalmente o espectador, do que aproximá-lo:

The mere want of fortune, mere poverty, excites little compassion. Its complaints are too apt to be the objects rather of contempt than of fellow-feeling. We despise a beggar; and, though his importunities may extort an alms from us, he is scarce ever the object of any serious commiseration (SMITH, 1984 [1759], p. 144).

Alguns autores reforçam que esta consideração explica a atitude negativa predominante em relação aos pobres: “a razão que Smith fornece para este comportamento é um caso clássico de negação: humanos têm uma aversão natural às experiências dolorosas, o que os fazem suprimir qualquer identificação com aqueles que experenciam aflições” (BIRCH, 1998, p. 30). Enquanto esta tendência de "suprimir" a possibilidade de simpatia com paixões negativas não é particular de consequências específicas da pobreza, ela tende a ser mais intensa neste caso justamente devido à frequente falta de entendimento e aprovação da condição do pobre.

As possibilidades de comportamento benevolente, dependentes da simpatia motivando a caridade, são, portanto, bastante limitadas. Isto não significa, contudo, que a benevolência dirigida ao pobre, dentro do sistema de Smith, seja completamente impossibilitada. Uma vez que é possível aprovar a propriedade do sofrimento alheio sem simpatizar com o mesmo, seria possível (em desafio às próprias emoções viesadas do espectador) fornecer auxílio voluntário pela mera consideração de que é isso o que um "espectador imparcial" faria. Esta figura imparcial, que estaria "dentro do próprio peito" de cada homem, serviria como o mais alto árbitro na Terra do que seria certo ou errado (e apropriado ou inapropriado), e representa uma consciência que todos possuiriam dentro de si (SMITH, 1984 [1759], p. 130-131). A origem deste espectador imparcial é mista: parte divina, parte social. É uma figura que age no homem como um "semideus" mitológico (SMITH, 1984 [1759], p. 131), e nos direciona à uma moral verdadeiramente universal na visão de Smith (SHIN, 2005, p. 1-2) ${ }^{11}$.

Essa capacidade do homem de imaginar um "espectador imparcial" permitiria, em casos particulares, a possibilidade de realizar atos virtuosos (no caso, benevolentes), mesmo que nossas simpatias naturais não sejam direcionadas àqueles que mais sofrem: “o problema é como

\footnotetext{
${ }^{11}$ Shin (2005), argumenta que Smith dá uma significância moral universal e divina inapropriada ao espectador imparcial, e que, seria mais adequado, se este fosse considerado meramente como um conjunto de julgamentos sociais da comunidade que influencia o indivíduo. Entretanto, embora seja verdade que há um caráter de moral universal e de origem divina do espectador imparcial na TMS, Smith é explícito que tal origem divina é apenas "em parte" o que compõe o espectador imparcial, e que, há, ainda, um tribunal superior ao da consciência: o de Deus, na vida após a morte. Este tribunal superior, por sua vez, também possui efeitos diretos no comportamento humano, uma vez que é "profundamente enraizado na natureza humana" a crença neste julgamento final (SMITH, 1984 [1759], p. 131-132).
} 
podemos, como espectadores parciais, transformar-nos em imparciais, e tornar-nos conscientes de nossas simpatias naturais" (LAMB, 1974, p. 676). Esta discussão, contudo, do como agir de modo virtuoso, será realizada na próxima seção.

A tendência em não simpatizar com paixões negativas, e, portanto, com os menos afortunados na sociedade, é invertida quando trata-se de paixões positivas, e, portanto, com pessoas afortunadas, ricas, bem sucedidas (SMITH, 1984 [1759], p. 50). Quando leva-se em conta tal predisposição, se torna possível completar a explicação da grande força do autointeresse material nas ações humanas, pois, ciente de que será admirado pelas suas riquezas, ciente que a simpatia da sociedade converge àqueles que acumulam e não chega àqueles que carecem economicamente, o indivíduo, na sua tentativa natural de obter a simpatia alheia, priorizará a sua riqueza sobre a dos demais.

Tal mecanismo é mais precisamente definido pela síntese desta propensão a simpatizar com os mais afortunados com fenômeno da simpatia mútua, que nada mais é que o prazer de saber que alguém está simpatizando com suas próprias paixões, sejam elas positivas ou negativas ${ }^{12}$. É tanto o desejo de obter a simpatia alheia demonstrando seus próprios prazeres (que tenderia a ocorrer quando se é rico), e é tanto o medo de não obter a simpatia dos outros (que tenderia a ocorrer quando se é pobre), que naturalmente há um incentivo à busca pela acumulação de riquezas:

Nothing is so mortifying as to be obliged to expose our distress to the view of the public,
and to feel, that though our situation is open to the eyes of all mankind, no mortal
conceives for us the half of what we suffer. Nay, it is chiefly from this regard to the
sentiments of mankind, that we pursue riches and avoid poverty (SMITH, 1984 [1759],
p. 50)

Em outras palavras, o comportamento materialista auto interessado resulta de um lado da presença da simpatia mútua, e de outro, da tendência natural à simpatizar mais facilmente com aqueles que estão em condições confortáveis economicamente.

Ironicamente, os prazeres da simpatia mútua em relação às paixões positivas, seriam muito menores que os o alívio (ou prazeres) da simpatia mútua em relação às paixões negativas.

\footnotetext{
${ }^{12}$ Smith destaca que, ao simpatizar, mesmo com o sofrimento alheio, sentimos um prazer de compartilhar a paixão entendendo o outro - que, talvez, mais que compensaria a dor absorvida pela simpatia (SMITH, 1984 [1759], p. 15-16). Contudo, se esta "simpatia mútua" falha em se estabelecer, tanto a pessoa observada (que falha em obter a simpatia alheia) como a pessoa que observa (que falha ao tentar simpatizar com o próximo) sofrem. Um exemplo de simpatia mútua dado por Smith é a nossa grande alegria ao perceber que um amigo aprova um livro ou um poema que você gosta muito. Há um prazer adicional ao observar que ele compartilha desta paixão com você. Contudo, se ele desaprova o livro em questão, há um desconforto forte causado pela tentativa falha de simpatia mútua (SMITH, 1984, p. 14). Para situações negativas, como os desconfortos da pobreza, esta falha causa um desconforto ainda mais intenso (SMITH, 1984 [1759], p. 15).
} 
Isto é, ainda que seja mais fácil simpatizar com o sucesso e alegrias, há pouco benefício para quem já está em uma boa situação em receber esta simpatia, enquanto é mais difícil simpatizar com tristezas e sofrimento, sendo enorme o benefício de receber a simpatia nestes casos.

Outro fenômeno que se destaca nestas tentativas de obter a simpatia alheia (estabelecer a simpatia mútua) é que a falta de conexão, quando ela ocorre, penaliza não só o indivíduo observado, como também o espectador em questão, mas apenas nos casos em que aprovamos sem simpatizar (que sentimos que deveríamos simpatizar):

(...) it is always disagreeable to feel that we cannot sympathize with him, and instead of being pleased with this exemption from sympathetic pain, it hurts us to find that we cannot share his uneasiness (SMITH, 1984 [1759], p. 16).

Existem outras considerações que podem explicar a indiferença ao pobre e a atenção dada aos detalhes da vida dos mais ricos. Algum grau de novidade, por exemplo, parece ser uma condição necessária para o estabelecimento da simpatia:

The chief cause, however, why such objects produce such violent effects upon us, is
their novelty. One who has been witness to a dozen dissections, and as many
amputations, sees, ever after, all operations of this kind with great indifference, and
often with perfect insensibility. Though we have read or seen represented more than
five hundred tragedies, we shall seldom feel so entire an abatement of our sensibility to
the objects which they represent to us (SMITH, 1984 [1759], p. 30).

E que novidade seria a pobreza de alguém em um país pobre? Nenhuma praticamente. Já em um país próspero, ou menos desigual, a miséria é um desvio tão expressivo da normalidade, que a simpatia facilmente poderia se revelar. Extrapolando um pouco para outro contexto a visão de Smith, não seria um salto tão grande esperar que, dada a importância da simpatia como condição para a caridade, países mais pobres tenham menores contribuições filantrópicas que países ricos, ainda que levada em conta a relatividade proporcional da diferença de rendas.

Além de todas as barreiras já descritas, Smith adiciona a dificuldade inerente de simpatizarmos com dores e prazeres físicos, ao passo que paixões mentais são facilmente objetos de nossa simpatia:

The frame of my body can be but little affected by the alterations which are brought about upon that of my companion: but my imagination is more ductile, and more readily assumes, if I may say so, the shape and configuration of the imaginations of those with whom I am familiar. The loss of a leg may generally be regarded as a more real calamity than the loss of a mistress. It would be a ridiculous tragedy, however, of which the catastrophe was to turn upon a loss of that kind. A misfortune of the other kind, how frivolous soever it may appear to be, has given occasion to many a fine one (SMITH, 1984 [1759], p. 29). 
É verdade que muitas das necessidades de benevolência são psicológicas. A solidão, depressão e medo, por exemplo, são importantes objetos da benevolência através da mera presença da sensibilidade alheia. Contudo, a fome, a falta de saúde, o cansaço e as dores do trabalho intensivo e prolongado, todas estas características de uma condição de pobreza extrema seriam facilmente negligenciadas pela nossa natureza.

Soma-se a todas as restrições à simpatia aos pobres o fato de que estes possuem receio de revelar seu próprio sofrimento (SMITH, 1984 [1759], p. 46), ou seja, a "tendência do pobre em ocultar sua condição devido a um sentido de vergonha e medo de desaprovação social" (BIRCH, 1998, p. 26). Este é um fenômeno que é tanto causa da dificuldade de estabelecer simpatia (afinal, a ocultação da pobreza impede que sua verdadeira extensão seja conhecida), como consequência desta dificuldade - pois o pobre, sabendo que terá dificuldades em atrair a simpatia alheia, prefere (com razão, como veremos adiante), esconder seu sofrimento.

Assim, é verdade que possuímos certa “propensão a simpatizar" em muitos casos, como Coase (1976, p. 2) argumenta, mas a análise parece indicar que esta propensão é radicalmente diferente no caso de paixões positivas vis-à-vis paixões negativas. Como Birch (1998) aponta, existe "um conjunto poderoso de barreiras psicológicas desencorajando atos de caridade para com os pobres". Talvez fosse mais correto afirmar que temos uma propensão à tentar simpatizar e a buscar a simpatia alheia. E enquanto a simpatia mútua pode "reforçar" esta propensão devido aos prazeres que ela traz, não se pode ignorar o risco de que ela não se realize, que acompanha estes possíveis benefícios. Se tomássemos a liberdade de realizar uma análise utilitarista (ainda que Smith não o faça) e somarmos aos custos e riscos de tentar simpatizar com o sofrimento transmitido através de paixões negativas, além do próprio custo econômico de realizar um ato de caridade, percebemos que a benevolência impulsionada pela simpatia parece tão frequentemente inalcançável, e, deste um ponto de vista utilitarista, até mesmo deficitário para quem se dispõe a observar o sofrimento alheio, na maior parte dos casos. Tal conclusão derivada do mecanismo de simpatia em Smith seria compatível com a de Bentham quanto às possibilidades de caridade privada, o que será explorado mais adiante no trabalho.

O tom de Smith na TMS é de otimismo pela mera existência da simpatia, mas ele a apresenta direcionada aos interesses dos ricos e poderosos; exigente de novidade para que a atenção do observador seja captada; e carente de incentivos adequados para sua realização. Os argumentos, portanto, parecem indicar que são amplas as barreiras para que se estabeleça uma simpatia com o sofrimento alheio capaz de levar à benevolência. Parece que sem intenção de assim fazê-lo, o autor estrutura os pré-requisitos para o surgimento a simpatia de modo bastante 
restritivo. O seguinte quadro expõe as principais diferenças quanto as facilidades e dificuldades de simpatizar com ricos e pobres, respectivamente:

Tabela 1 - Diferenças na facilidade de simpatizar com o rico versus o pobre

\begin{tabular}{|l|l|}
\hline $\begin{array}{l}\text { Rico: Razões pelas quais a simpatia tende a } \\
\text { se estabelecer }\end{array}$ & $\begin{array}{l}\text { Pobre: Razões pelas quais a simpatia tende } \\
\text { a não se estabelecer }\end{array}$ \\
\hline Paixão positiva (transmite alegria na simpatia) & Paixão negativa (transmite dor na simpatia) \\
\hline $\begin{array}{l}\text { Paixão positiva: } \\
\text { intensidade raramente é excessiva }\end{array}$ & $\begin{array}{l}\text { Paixão negativa: } \\
\text { intensidade difícil de compreender }\end{array}$ \\
\hline $\begin{array}{l}\text { Exceção, “novidade” } \\
\text { Prazeres mentais }\end{array}$ & Usual \\
\hline Alegrias ostentadas (por orgulho) & Sofrimento físico \\
\hline
\end{tabular}

Um argumento que poderia ser levantado contra o resumo das diferenças expressas por Smith resumidas na tabela acima é que o próprio autor, em determinados momentos, afirma que a pobreza (exceto a extrema) não é necessariamente um malefício, ao mesmo tempo que a riqueza não é uma benção (SMITH, 1984 [1759], p. 50, p. 64, p. 181) - isto é, o rico, enquanto possui um conforto material superior, frequentemente sofre com responsabilidades e preocupase com vaidades, frivolidades que trazem mais dores do que felicidade genuína. Ao passo que o pobre, por sua vez, embora não tenha os benefícios materiais do rico, possuí uma vida com preocupações mais modestas e uma paz de espírito que muitos ricos desejariam ter. E, portanto, poderia se questionar: seriam tão negativas assim as paixões dos pobres em relação aquelas dos ricos (e faria sentido a distinção que fizemos em termos de propensão a simpatizar)?

A resposta a este argumento se encontra no fato de que a propensão à simpatizar é praticamente exclusiva às observações imediatas da condição alheia. Considerações secundárias, abstratas, raramente evocam a simpatia. Smith ilustra este fato através de exemplos: a construção de uma prisão, enquanto muito útil para a sociedade, tende a gerar um sentimento inicial de repulsa, isto por que a imagem imediata que nos fornece é de privação de liberdade, violência, etc. São apenas considerações secundárias que nos fariam aprovar a prisão, porém tais considerações são dificilmente catalisadoras da simpatia. A construção de um palácio, por sua vez, apesar de frequentemente custoso ou inútil à sociedade, causa um sentimento imediato agradável, simpatizamos com o efeito imediato da percepção do luxo, da beleza, do conforto, e dificilmente sentimos repulsa devido às considerações secundárias e 
abstratas que envolvem o desperdício de recursos, entre outros possíveis aspectos negativos mais abstratos na construção de um palácio (SMITH, 1984 [1759], p. 35-36). Analogamente, enquanto às paixões positivas dos ricos são evidentes, imediatas, como o conforto, as paixões negativas são secundárias, ocultas, como a deterioração de relações pessoais honestas, ambições não cumpridas, artificialidade e estresse com preocupações frívolas que corroem o espírito (SMITH, 1984 [1759], p. 181). Já as paixões imediatas que os pobres revelam são em geral negativas, relacionadas ao desconforto e óbvia privação econômica, enquanto a tranquilidade e sinceridade em uma vida modesta é uma consideração secundária, mais abstrata, que raramente seria levada em conta na formação das simpatias naturais.

Apesar da existência da simpatia ser o elemento essencial para tornar o homem um ser social, ela não é o único princípio da natureza humana em Smith. A seção seguinte tratará de outros elementos naturais do comportamento humano em Smith que também possuem consequências diretas ou indiretas para o tema da caridade e Lei dos Pobres.

\subsection{Para além da simpatia: inveja, gratidão e ressentimento}

Ao longo da TMS, certos instintos mais básicos do homem são apresentados independentes da simpatia. Smith faz questão, por exemplo, de explicitar que as sensações da “fome e sede, [...] do prazer e da dor, calor e frio, etc. podem ser consideradas como lições entregues pela própria voz da Natureza, direcionando [o homem] ao que ele deveria buscar, e ao que ele deveria evitar" (SMITH, 1984 [1759], p. 212). Todos estes instintos mais básicos influenciam o comportamento humano de modo direto, sem grandes mistérios. Há, contudo, outros aspectos psicológicos mais abstratos e sociais também impostos pela natureza humana e relevantes à questão da benevolência, mas que, ao contrário daqueles tratados na seção anterior, não são diretamente conectados com a simpatia (apesar de se articularem com ela).

Uma paixão que parece surgir no sistema de Smith de modo independente da simpatia é a inveja. De fato, a inveja alteraria a nossa própria propensão a simpatizar: enquanto a ausência deste sentimento manteria a tendência geral de simpatizar mais com a alegria do que com o sofrimento, sua presença pode inverter esta lógica (SMITH, 1984 [1759], p. 44-45), tornando-se mais fácil simpatizar com pessoas em posição inferior e mais difícil simpatizar com 
pessoas em posição superior ${ }^{13}$. Pensando desta maneira, seria a inveja "útil" para reduzir desigualdades? Ou seja, "a inveja seria moralmente condenada apesar da aparente presença de um importante componente moral, especificamente, o desejo de eliminar a desigualdade" $\left(B E N-Z E ' E V, 1992\right.$, p. 551) ${ }^{14}$ ? No sistema de Smith a resposta é negativa. A definição de inveja de Smith é "aquela paixão que enxerga com desgosto maldoso a superioridade daqueles que são verdadeiramente merecedores ${ }^{15}$ de toda a superioridade que possuem" (SMITH, 1984 [1759], p. 244). Assim, segundo Smith, a inveja seria um sentimento destrutivo gerado a partir da própria percepção de inferioridade, e não uma paixão relacionada a uma suposta superioridade desmerecida do outro (BEM-ZE’EV, 1992, p. 552). Como será discutido posteriormente, tal posição se encaixa com o fato de que Smith vê com bons olhos a ordem natural na qual as desigualdades se manifestam - e, portanto, condena a inveja como um vício, uma "fraqueza comumente baseada em indolência" (SMITH, 1984 [1759], p. 244). A natureza do homem, contudo, é tal que o sentimento de inveja seria frequentemente seguido de "arrependimento" e que "para viver confortavelmente no mundo, é necessário, em todas ocasiões, defender a dignidade posição social, assim como é necessário proteger a vida e fortuna"16 (SMITH, 1984 [1759] , p. 244), ou seja, Smith concebe ataques à desigualdade de riqueza e posição social como destrutivos à ordem natural.

A inveja, entretanto, é parte de um conjunto mais amplo de paixões na obra de em Smith, que estão relacionadas ao mérito e demérito. Para compreender este conjunto é necessário observar uma distinção fundamental: na TMS, separa-se claramente o sentimento de propriedade (aprovação ou reprovação; proporcionalidade ou desproporcionalidade de uma ação ou paixão em relação a sua causa) do sentimento de mérito ou demérito, que se relaciona a efeitos positivos ou negativos de uma ação. Isto é, propriedade é essencialmente baseada nas causas da ação (motivada por uma paixão) observada - "um julgamento de propriedade é apenas sobre o motivo e não inclui também o pensamento sobre consequências" (RAPHAEL, 2007, p. 24-25) - enquanto o mérito é baseado nas consequências de uma ação (SMITH, 1984 [1759], p. 244).

Os nomes dados às paixões decorrentes do mérito e do demérito são, respectivamente, "gratidão" e "ressentimento" (SMITH, 1984 [1759], p. 67-70). Enquanto a gratidão surge

\footnotetext{
${ }^{13}$ Para tornar claro: a inveja não surge a partir da simpatia no sistema apresentado por Smith. Entretanto, a influência da inveja sobre a manifestação da simpatia é expressiva.

${ }^{14}$ Esta é uma questão que Bem-ze'ev levanta, e, baseado nas ideias de Smith e outros autores, rejeita a ideia.

15 "entitled".

${ }^{16}$ Esta afirmação de Smith pode soar estranha ao leitor mais acostumado com a WN do que a TMS. Observa-se, de fato, certa diferença quanto à perfectibilidade que Smith reconhece na ordem natural entre os dois livros, o que será discutido na seção: "Instituições e a ordem natural".
} 
naturalmente da percepção de que uma ação com consequências positivas para o indivíduo que às recebe foi realizada, o ressentimento surge da percepção de que tal ação causou mal ao indivíduo que sofre as consequências de uma determinada ação. Esta definição é intuitiva e se mantém no vocabulário atual. Entretanto, é interessante notar que há implicações relevantes para uma teoria da caridade em Smith quando esses sentimentos individuais são associados ao fenômeno da simpatia. Isto é, por meio da simpatia, a gratidão para com seu benfeitor se torna uma paixão coletiva, compartilhada por todos que observam a boa ação, de onde surge uma propensão a recompensar o benfeitor. Smith denomina este fenômeno de "simpatia indireta" (SMITH, 1984 [1759], p. 74). Da mesma maneira, uma injúria, se observada por terceiros, torna coletivo o ressentimento do indivíduo injuriado, de onde se origina a propensão da sociedade a punir quem causa tal injúria, ainda que esta não seja contra cada indivíduo na sociedade ${ }^{17}$. Especificamente quanto a um ato de benevolência gerador de gratidão Smith observa por exemplo que:

\begin{abstract}
When we see one man assisted, protected, relieved by another, our sympathy with the joy of the person who receives the benefit serves only to animate our fellow-feeling with his gratitude towards him who bestows it. When we look upon the person who is the cause of his pleasure with the eyes with which we imagine he must look upon him, his benefactor seems to stand before us in the most engaging and amiable light (SMITH, p. 70, 1984 [1759]).
\end{abstract}

Apesar de a gratidão (e de o ressentimento) poder ser generalizada através da simpatia, não há contudo, garantia de que isso necessariamente ocorrerá - como já foi discutido, o estabelecimento do vínculo simpático demanda aprovação, ou seja, é necessário que a gratidão (ou ressentimento) seja considerada apropriada, seja aprovada (SMITH, 1984 [1759], p. 71-73). Se, por exemplo, manifesta-se imensa gratidão em reação a uma doação realizada por motivos triviais (e não por uma benevolência que demanda autocomando ${ }^{18}$ ), é mais difícil sentir simpatia (compartilhar a gratidão) se comparado com situações em que a doação requer um maior exercício das virtudes do doador. Um exemplo seria o caso de uma doação dentro de uma família rica - enquanto a pessoa que a recebe possa estar bastante grata, o motivo para a doação não é julgado próprio por um espectador imparcial:

\footnotetext{
${ }^{17}$ A gratidão e o ressentimento, coletivamente compartilhados através da simpatia, são claramente "leis naturais" para Smith, e elogiadas pelo autor. No caso específico do ressentimento ele destaca: "A Natureza, adiantando-se de qualquer reflexão quanto à utilidade da punição, gravou desta maneira sobre o coração humano da maneira mais forte e permanente, uma imediata e instintiva aprovação da sagrada e necessária lei da retaliação" (SMITH, p. 71, 1984 [1759]).

18 "Autocomando" é a capacidade de controle de suas próprias paixões, exercido para agir de modo virtuoso, superando tentações (que levaria ao vício). O conceito será explorado em maior detalhe posteriormente.
} 
[...] wherever there seems to be no propriety in the motives which influenced his conduct, we are less disposed to enter into the gratitude of the person who received the benefit of his actions. A very small return seems due to that foolish and profuse generosity which confers the greatest benefits from the most trivial motives, and gives an estate to a man merely because his name and sirname happen to be the same with those of the giver (SMITH, 1984 [1759], p. 72).

O mesmo é válido para o caso de um ressentimento julgado inapropriado, o que caracteriza o caso específico da inveja: se trata de um ressentimento (um julgamento individual de demérito), que um espectador imparcial consideraria inapropriado - uma vez que as consequências do sucesso relativo alheio não seriam, no caso, negativas o suficiente para justificar o ressentimento que o indivíduo manifesta. Do mesmo modo, um indivíduo que sofre as consequências negativas de seus próprios crimes ou vícios, os quais ele teria livremente escolhido fazer, expressa pouca simpatia em seu ressentimento com as punições que a sociedade decide lhe impor (SMITH, p. 73, 1984 [1759]).

Neste sistema de gratidão e ressentimento desenhado por Smith, torna-se evidente um incentivo à benevolência "apropriada", isto é, a benevolência que se apresenta altruísta e com custos reais ao benfeitor, pois neste caso: "Suas ações parecem demandar, e, eu poderia dizer, clamar por uma recompensa proporcional. Nós então adentramos naquela gratidão que a induz [à recompensa]" (SMITH, 1984 [1759], p. 73), tal perspectiva implica que somos capazes de julgar intuitivamente diferentes versões de atos benevolentes, mais ou menos apropriados. Como será visto, esta é uma consideração que permite paralelo com a perspectiva de Malthus quanto à caridade, que será exposta mais adiante: ambos diferenciam qualitativamente diferentes atos de benevolência.

Ademais, qualquer manifestação de descontentamento com uma posição social e econômica relativamente inferior por parte do pobre tende a ser entendida como inveja, uma paixão apropriadamente condenável e que tende apenas a aprofundar a vergonha do pobre com sua própria condição. Como será visto posteriormente, este mecanismo é consistente com a recomendação de Smith ao pobre que pretende receber auxílio: esconder em parte seu sofrimento, não demonstrar ira, nem desespero, e muito menos inveja - afinal, a benevolência é uma virtude que requer (via de regra) simpatia, e a simpatia demanda o entendimento e a aprovação do observador, para que ele livremente sinta-se inspirado a auxiliar o pobre. A seção seguinte explícita este caráter central do ato de benevolência: a ausência de compulsão daquele que o realiza. 


\title{
2.3. O caráter voluntário do ato benevolente
}

Benevolência, como já mencionado, é uma das grandes virtude no sistema de Smith. A caridade, por sua vez, é uma manifestação desta virtude, e deve ser necessariamente voluntária:

\begin{abstract}
Beneficence is always free, it cannot be extorted by force, the mere want of it exposes to no punishment; because the mere want of beneficence tends to do no real positive evil. (...) We must always, however, carefully distinguish what is only blamable, or the proper object of disapprobation, from what force may be employed either to punish or to prevent. (...) Even the most ordinary degree of kindness or beneficence, however, cannot, among equals, be extorted by force (SMITH, 1984 [1759], p. 78).
\end{abstract}

A definição de um ato benevolente de caridade como necessariamente voluntário se conecta com a questão do ressentimento (e a possibilidade de ele não ser apropriado) discutido na seção anterior. Para Smith, este caráter voluntário segue diretamente da impropriedade de um ressentimento conectado à ausência do ato benevolente, ou seja, é inapropriado sentir ressentimento por alguém que não foi benevolente em seu favor. Isto por que: "a mera ausência de benevolência não causa nenhum mal positivo" - positivo no sentido de "direto" ou "prático" da palavra (SMITH, p. 78, 1984 [1759]). Este trecho da TMS parece ser explícito o suficiente para deduzir que, pelo menos no contexto desta obra, um auxílio estatal aos pobres através de uma distribuição forçada de riqueza, uma "caridade involuntária", uma Lei dos Pobres mais relaxada, tal qual o sistema de Speenhamland, seria condenável. A questão, contudo, é controversa $^{19}$. Um autor que defende esta interpretação - de que o posicionamento de Smith quanto a questão da caridade é fundamentalmente uma que respeita o caráter voluntário do ato - é Winch (1998). Para ele, a percepção de que a obra de Smith traria uma versão mais “otimista" em termos de assistência aos pobres (do que a obra de Malthus por exemplo) é equivocada, ou, pelo menos, inadequada - como veremos na seção adiante, a dificuldade de simpatizar com o pobre tornando os atos de benevolência raros e restritos não é necessariamente algo ruim na natureza humana, as desigualdades seriam parte da ordem natural e devem ser respeitadas. Desse modo, seria errado interferir com o uso de força neste arranjo de sentimentos morais. A conclusão de Winch, portanto, complementa o argumento de que caridade é essencialmente voluntária na TMS:

Smith is arguing the hard-headed case: this is how things are because that is how we are most of the time, with the further implication, however, that things are best arranged in

19 Autores como Birch (1998) acreditam que haveria espaço, mesmo na TMS, para assistência pública, compulsória, no alívio à pobreza. 
this manner. The result is that beggars become contemptible in our eyes, poverty is seen as avoidable, and charity must be purely voluntary (WINCH, 1998, p. 15).

Seria um erro, contudo, deduzir a partir daí que Smith está defendendo o egoísmo, ou condenando a benevolência - pelo contrário, os obstáculos à benevolência impostos pela simpatia (incluindo a necessidade de que ela seja voluntária) apenas valorizam o ato de caridade, quando realizado. Ainda assim, ele precisa ser voluntário dentro deste ponto de vista. Do outro lado do argumento Birch (1998) questiona a suposta necessidade do ato benevolente ser voluntário. Sua objeção decorre especificamente de exceções encontradas na TMS: "Na Teoria dos Sentimentos Morais, Smith foi muito cuidadoso quanto a dar ao governo autoridade direta sobre atos que requerem benevolência, mas ele não excluiu por completo tal função" (BIRCH, 1998, p. 32). Smith explica que o governante, entre suas várias funções, poderia em casos específicos "comandar bons ofícios até certo ponto" (SMITH, 1984 [1759], p. 81). Há duas razões para descartar esta interpretação de Birch: primeiro, ela seria incoerente com a dedução realizada a partir da impossibilidade de se estabelecer simpatia indireta através de um ressentimento originado da ausência de benevolência alheia. Segundo, lido em contexto, o trecho a que Birch se refere é precedido pelo exemplo da obrigação que o Estado pode impor aos pais de uma criança que sejam benevolentes em relação à esta, compulsoriamente. Neste caso, não há incoerência no pensamento de Smith. A ausência de benevolência de pai para filho, ao violar a expectativa natural de todos espectadores (inclusive de um espectador imparcial), é completamente inapropriada. Assim, a ausência do cuidado parental certamente evoca simpatia com o ressentimento da criança negligenciada para com o pai ${ }^{20}$. Ademais, Smith qualifica e alerta que, tais "bons ofícios" comandados devem ser dirigidos com muito cuidado, pois seria completamente irresponsável ignorar o julgamento da natureza humana quanto a propriedade ou impropriedade do uso da força nestes casos. Seria, de fato, desastroso passar deste "certo grau" de moderação em que o poder do Estado pode ser exercido para guiar ou forçar atos que deveriam ser voluntários:

Of all the duties of a law-giver, however, this, perhaps, is that which it requires the greatest delicacy and reserve to execute with propriety and judgment. To neglect it altogether exposes the commonwealth to many gross disorders and shocking enormities, and to push it too far is destructive of all liberty, security, and justice. (SMITH, 1984 [1759], p. 81)

\footnotetext{
${ }^{20}$ Lembrando que, dada a natureza da simpatia, não há necessidade da criança realmente sentir tal ressentimento para que se estabeleça simpatia - entende-se e aprova-se o ressentimento que o espectador sentiria no lugar da criança, a simpatia pode se estabelecer independentemente da manifestação da paixão por parte do indivíduo observado.
} 
Assim, pelo menos no âmbito da TMS, o argumento de que Smith estaria disposto a apoiar um programa compulsório de alívio à pobreza é questionável, no melhor dos casos. Uma intepretação mais precisa é que o caráter necessariamente voluntário do ato benevolente é o que separa esta virtude da virtude da justiça, que permite o uso da força e será definida na seção seguinte.

\subsection{As grandes virtudes e o ato de caridade}

Neste capítulo, veremos como o exercício das virtudes delineadas por Smith se relacionam com a realização de um ato de caridade. São quatro virtudes fundamentais no pensamento exposto na TMS, sendo as mais que se articulam de modo específico ao tema da caridade são a benevolência e o autocomando. As seguintes definições aproximadas podem ser utilizadas para cada uma das quatro virtudes: (i) "prudência” é aquela virtude que leva o indivíduo à buscar sua própria felicidade (SMITH, 1984 [1759], p. 212); (ii) “justiça” é aquela virtude que impede o indivíduo de causar mal ao próximo (SMITH, 1984 [1759], p. 218); (iii) "benevolência" é aquela virtude que leva o indivíduo a realizar bem ao próximo (SMITH, 1984 [1759], p. 218); (iv) e "autocomando" é a capacidade do indivíduo de controlar suas próprias paixões, permitindo que suas ações se tornem mais apropriadas, sendo a virtude necessária para o exercício adequado de todas as demais virtudes (SMITH, 1984 [1759], p. 241). Vale a pena comentar certos detalhes específicos de cada uma das virtudes em relação a sua influência sobre a caridade (ainda que, como já deve estar claro, a benevolência já tenha sido discutida extensamente até então).

Quanto à prudência, destaca-se que não há conflito entre a virtude da prudência e da benevolência. Isto é, a busca pela própria felicidade, para Smith, não prejudica o exercício de atos em prol da felicidade alheia. Há pouco mais na TMS que conecte a prudência à benevolência - apenas que Smith descreve o homem prudente como um homem simples e modesto, e que, quando grandes responsabilidades lhe são atribuídas, não é por que este as buscou de modo ambicioso (SMITH, p. 212-217, 1984 [1759]). Isto é, uma vida tranquila (e não esplendorosa) é o objeto que busca o homem prudente, e, portanto, nada o impede de exercer caridade, na medida em que não seja excessiva.

A justiça, por sua vez, determinaria quando o uso de força é legítimo na sociedade. De modo geral, um homem que possui a virtude de ser justo não apenas deixa de causar mal aos 
demais, mas também exerce ações apropriadas para evitar que outros causem mal aos demais. Naturalmente, é sobre o Estado que recai a maior parte da responsabilidade de exercer esta virtude, e, portanto, é sob a óptica da justiça que Smith definirá as principais instituições públicas necessárias para o bom funcionamento da sociedade. Na TMS, Smith evita uma discussão prolongada do tema da justiça, indicando que seria necessária outra obra para tal (SMITH, 1984 [1759], p. 218). É apenas em suas Lectures on Jurisprudence ${ }^{21}$ (em suas primeiras Lectures de 1762), que Smith detalha como a sociedade, e mais especificamente, o Estado, deve organizar suas instituições de modo a garantir a justiça - centrada na garantia da propriedade dos indivíduos:

The first and chief design of every system of government is to maintain justice; to prevent the members of a society from encroaching on one another's property, or seizing what is not their own. The design here is to give each one the secure and peaceable possession of his own property (SMITH, 1978 [1762], p. 5).

Assim, fica clara a distinção entre justiça e benevolência - enquanto uma é um dever do homem não causar mal a outro, tornando apropriado o uso da força para garantir a justiça, não é um dever causar bem ao próximo, tornando inapropriado o uso da força para garantir (na grande maioria dos casos) a benevolência, como já discutido ${ }^{22}$. Desse modo, haveria uma importância maior a manutenção da justiça do que o exercício da benevolência. É mais importante, por exemplo, garantir a propriedade privada do que garantir que esta seja generosamente distribuída. E como em vários pontos da TMS, a recomendação de Smith de como a sociedade deve se organizar, corresponde ao modo que a natureza humana faz com que ela se organize organicamente - ainda que o exercício das grandes virtudes seja necessário para calibrar nossas paixões:

$[\ldots]$ the greatly fortunate and the greatly unfortunate, the rich and the powerful, the poor and the wretched. The distinction of ranks, the peace and order of society, are, in a great measure, founded upon the respect which we naturally conceive for the former. The relief and consolation of human misery depend altogether upon our compassion for the later. The peace and order of society, is of more importance than even the relief of the miserable. Our respect for the great, accordingly, is most apt to offend by its excess; our fellow-feeling for the miserable, by its defect (SMITH, 1984 [1759], p. 225-226).

${ }^{21}$ Doravante "LJ"

${ }^{22}$ Através da LJ, é possível observar um complemento importante à discussão da caridade ser necessariamente voluntária ou potencialmente exercida pelo Estado. O pedido de um mendigo, por exemplo, não resulta no direito de receber a caridade (existe apenas o direito de realizar o pedido), e portanto, não resulta em obrigação por parte da sociedade em realiza-la (SMITH, p. 9, 1978 [1762]), - já em outros casos, se exige que uma responsabilidade seja assumida involuntariamente, como no caso em que uma criança se torna órfã e precisa ser criada e sustentada pelo parente mais próximo por parte do pai (SMITH, 1978 [1762], p. 457). 
Em suma: a virtude da justiça é superior em importância à benevolência. Esta, é apenas um "ornamento", enquanto a justiça é o "pilar" para o bom funcionamento da sociedade (SMITH, 1984 [1759], p. 86).

Já ao tratar da virtude da benevolência especificamente, adicionando a análise realizada até então, Smith inicialmente explicita uma ordenação em que tal virtude normalmente é (e deve ser) exercida. $\mathrm{O}$ homem benevolente deve cuidar: primeiramente da própria felicidade (prudência), em seguida de sua família, de seus amigos, e de seu país (SMITH, 1984 [1759], p. 237). Novamente, a noção normativa dos "círculos de simpatia" aparece de modo compatível com a nossa natureza de simpatizar mais facilmente com aqueles próximos, dos quais podemos mais facilmente entender a situação, do que com indivíduos mais distantes. Isto é, aquilo que é recomendado por Smith, moralmente, é também naturalmente o que se observa em nossa natureza, neste caso. A benevolência universal, isto é, que se preocupa excessivamente com todos os seres do mundo sem priorizar aqueles mais próximos, é considerada potencialmente negligente e insensata, uma vez que pode tornar insuficiente o exercício da benevolência direcionada àqueles mais próximos (que dificilmente serão auxiliados por outras pessoas distantes) e, ao mesmo tempo, demonstra uma falta de fé na capacidade de Deus de cuidar da felicidade do universo como um todo:

\footnotetext{
The administration of the great system of the universe, however, the care of the universal happiness of all rational and sensible beings, is the business of God and not of man. To man is allotted a much humbler department, but one much more suitable to the weakness of his powers, and to the narrowness of his comprehension; the care of his own happiness, of that of his family, his friends, his country (SMITH, 1984 [1759], p. 237).
}

Outra forma de entender a virtude da benevolência, conectada diretamente com um ato de caridade, é a ideia da realização de um maior esforço, ou talvez mais adequadamente, a presença de uma maior disposição a simpatizar do que o usual, uma disposição acima daquela mínima que um espectador imparcial julgaria apropriado. Enquanto é verdade que a simpatia mútua não se estabelece de modo pensado racionalmente (SMITH, 1984 [1759], p. 13-14) também é verdade que o observador, quando colocado em uma situação em que ele tenta simpatizar, pode fazer um maior ou menor esforço neste sentido. Smith denomina este esforço de "amabilidade", "sensibilidade", ou até mesmo "humanidade" (SMITH, 1984 [1759], p. 2324) - que posteriormente são concatenadas no grupo de virtudes "benevolentes".

Uma maneira de interpretar esta contraposição entre a simpatia ser não racional, e ao mesmo tempo, o indivíduo ser capaz de se esforçar para alcançá-la, é compreender este esforço 
como uma luta intencional contra a própria natureza do observador - indo além de sua predisposição normal ou esperada. Desse modo, Smith está lidando aqui com a manifestação da benevolência através do autocomando. Assim como apenas um indivíduo capaz de controlar seus impulsos pode ser prudente e/ou justo, um indivíduo realmente benevolente requer autocomando para superar barreiras que costumam impedir que a simpatia se estabeleça e se manifeste através de um ato de benevolência. Isto é, se, por uma dificuldade de entendimento há obstrução da simpatia, e o observador perceber que ele não sente uma propensão em compartilhar com as dores do outro, ele sempre pode, através do autocomando, realizar um esforço para buscar entender melhor a situação alheia, ao invés de ignorá-la ou desaprová-la. Este caso é especialmente importante para buscar simpatia mútua com paixões negativas intensas, que são frequentemente intensas e desagradáveis, exigindo maior esforço do observador para compreendê-las.

O exercício do autocomando, quando relacionado especificamente à caridade, não seria uma virtude apenas por parte do doador. Talvez tão importante quanto o esforço para simpatizar por parte de quem observa o sofrimento alheio, para a realização de um ato benevolente, seja o exercício de um autocomando por parte de quem necessita do auxílio. Aquele capaz de se expressar de modo calmo e "silencioso", com uma tristeza "majestosa", "fria", "respeitosa" frente à clara miséria de sua condição (SMITH, 1984 [1759], p. 24) conseguiria facilitar o entendimento e aprovação alheia ao aproximar-se emocionalmente do observador e evitar um comportamento que poderia ser desaprovado e considerado insolente: He longs for that relief which nothing can afford him but the entire concord of the
affections of the spectators with his own. To see the emotions of their hearts, in every
respect, beat time to his own, in the violent and disagreeable passions, constitutes his
sole consolation. But he can only hope to obtain this by lowering his passion to that
pitch, in which the spectators are capable of going along with him. He must flatten, if I
may be allowed to say so, the sharpness of its natural tone, in order to reduce it to
harmony and concord with the emotions of those who are about him (SMITH, 1984
[1759], p. 22).

Assim, do ponto de vista do observador, como um ato de caridade evoca um sentimento “agradável”, a elevação dos esforços para realiza-lo tende a ser aprovada, ao passo que a manifestação da dor e do sofrimento da miséria econômica evoca um sentimento “desagradável”, e a redução destas manifestações tende a ser aprovada. A combinação destes dois esforços, por parte do doador e por parte do receptor facilita o estabelecimento da simpatia e a realização da caridade. Assim, o autocomando é chave na capacidade de simpatizar e facilitar a benevolência. 
Enfim, todas as seções até agora trataram de elementos da psicologia e da moral do homem relacionadas à caridade, já com conclusões significativas para o tema central: são numerosos os obstáculos da natureza humana à caridade; o ato benevolente é essencialmente voluntário; e as grandes virtudes (com exceção da justiça) favorecem o exercício da caridade.

Com base nesses mecanismos relacionados à simpatia, ao mérito e demérito e às virtudes em Smith, estamos em condições de realizar uma breve descrição de como esta ordem natural se articula com sua visão institucional, e, mais especificamente, como Smith trata a questão da Lei dos Pobres na Inglaterra.

\subsection{A ordem natural, papel do Estado e Lei dos Pobres}

Embora a WN seja a obra icônica representante do liberalismo de Smith (no sentido de negação da interferência estatal), pode-se dizer que é na TMS que seu ponto de vista liberal se manifesta de modo muito mais radical. Segundo Viner (1996 [1927], p. 207), a visão de Smith quanto à perfectibilidade da ordem natural é menos relativizada na TMS, fazendo com que a flexibilidade do autor quanto à aceitação às interferências artificiais sobre tal ordem sejam ainda mais facilmente rejeitadas do que na sua obra econômica liberal clássica. Esta perfectibilidade da ordem natural é de caráter divino, e, como veremos apresenta alguma similaridade com a visão de Malthus neste sentido ${ }^{23}$. Este ponto remete à uma outra questão que permeia a Teoria dos Sentimentos Morais, esta questão foi colocada adequadamente por Bianchi: "Seria ela uma obra de conteúdo positivo ou normativo? Em que medida estaria empenhada em difundir padrões morais, em que medida em retratar o movimento efetivo dos homens em sociedade?" (BIANCHI, p. 1988, p. 112). É verdade que, ao mesmo tempo que Smith está escrevendo um tratado ético, ele está simultaneamente, analisando "o homem como ele realmente é" (BIANCHI, 1988, p. 112). Uma possível resposta a esta questão é que o caráter positivo e normativo convergem na TMS. Ou seja: a ordem natural, como um todo, é perfeita na TMS -

\footnotetext{
${ }^{23}$ É importante uma distinção: tanto em Malthus como em Smith, há uma ideia de perfectibilidade daquilo que pode ser denominado de "ordem natural" que corresponde ao todo do sistema organizado por Deus. Isto se diferencia de um conjunto de leis naturais mais específicas que podem ser chamadas de "natureza humana", parte da ordem natural, mas não necessariamente perfeita em si. Não é contraditório, por exemplo, afirmar que existem vícios na natureza humana, e, que, ao mesmo tempo, no todo, a ordem natural é perfeita - existiriam mecanismos externos à natureza humana, mas presentes na ordem natural, que corrigiriam ou puniriam tais vícios, e incentivariam ou recompensariam virtudes. Ainda assim, no caso de Smith, a própria natureza humana é, em geral, perto de perfeita, necessitando apenas virtudes para calibra-la, evitando exageros. Já em Malthus, a natureza humana é bastante imperfeita, e a ordem natural externa mais ampla corrige-a implacavelmente.
} 
Smith está descrevendo tanto como as coisas são (na ausência de interferências artificiais) e como elas devem ser.

Este caráter de perfectibilidade da ordem natural, contudo, não se transpõe da TMS para a WN. Segundo Viner, existem algumas diferenças perceptíveis na visão geral de mundo entre as duas obras:

In the Theory of Moral Sentiments, this harmony [...] is represented as universal and perfect. In the Wealth of Nations, this harmony is represented as not extending to all elements of the economic order, and often as partial and imperfect where it does extend (VINER, 1996 [1927], p. 208)

Na TMS, esta harmonia perfeita é identificável em vários trechos em que Smith descreve a correspondência entre como é a natureza humana e como ela deve ser, para o bem maior. Isto significaria, portanto, como já mencionado, que o fato de ser naturalmente difícil simpatizarnos com os mais pobres não é necessariamente algo negativo de um ponto de vista moral. Significaria também que instituições de auxílio público estariam distorcendo esta ordem natural perfeita na qual as desigualdades entre as classes e a possibilidade de sofrer com graves dificuldades econômicas cumprem funções relevantes. Hanley (2009), por exemplo, observa que, para Smith (na TMS), a frequente ausência de simpatia pelo pobre possui uma utilidade: o desenvolvimento da prudência e do autocomando entre os pobres. Isto é, ao ter consciência da indiferença social existente em relação à miséria, o indivíduo evita ao máximo estar em uma condição em que ele terá que expressar seus infortúnios econômicos, “(...) encorajando em nós a industriosidade que evita recorrermos à mendicância" (HANLEY, 2009, p. 51). Esta visão, reforça a ideia de que a falta de simpatia aos menos afortunados não é uma "falha" da ordem natural, e sim uma parte adequada dela - e, portanto, o governo não deveria interferir nestas questões. Tal interpretação é válida para a TMS. O mesmo, contudo, não pode ser afirmado com tanta certeza para o Smith da WN. A percepção de que a ordem natural como um todo é perfeita deixa de ser válida, e nesse novo contexto, estranha-se a ausência de um posicionamento preciso quanto ao auxílio aos pobres na WN. Como Viner destaca:

It is quite probable that Smith overlooked some current activities of government to which he would given his approval if they had been called to his attention. The absence, for instance, in the Wealth of Nations of any discussion of poor relief as a public function has often been commented upon, and is generally regarded as having been due to oversight (VINER, 1996 [1927], p. 227-228).

Em outras palavras, apesar da certeza de que na TMS não há espaço para "forçar benevolência”, na WN, Smith é silencioso quanto a esta questão institucional. Dadas as várias 
falhas explicitadas na ordem natural apresentada na WN, a especulação de Birch (1998) de que um auxílio compulsório é compatível com a economia política de Smith não é completamente descabida. Um exemplo que demonstra esta mudança de comportamento de Smith da TMS para a WN quanto à perfectibilidade da ordem natural relacionada à desigualdade econômica seria a defesa impostos progressivos como política econômica na WN:

It is not very unreasonable that the rich should contribute to the public expense, not only in proportion to their revenue, but something more than in that proportion (SMITH, 1979 [1776], p. 106)

Teria Smith (assim como Bentham, que veremos mais adiante) se tornado gradualmente mais reformista com o passar do tempo? As observações de Viner (1996 [1927], p. 227-230) quanto as amplas possibilidades de reforma social previstas na WN sustentam que sim.

A evidência de uma flexibilização no papel do Estado da TMS para a WN é ainda mais aprofundada se observarmos que, a primeira obra, está fortemente relacionada a uma visão religiosa do mundo por parte de Smith (VINER, 1996 [1927], p. 199-201). As aparentes injustiças na ordem natural são meros erros do julgamento humano, inferior ao divino. $\mathrm{Ou}$ ainda, haveria a expectativa de que qualquer injustiça seria corrigida em um julgamento futuro após a morte (SMITH, 1984 [1759], p. 131-132). Na WN este tipo de elevação da ordem natural ao sagrado não está presente. Pelo contrário, na WN, Smith defende uma série de intervenções específicas, artificiais, o que leva comentaristas a caracteriza-lo como "um pensador social pragmático que em cada caso selecionava a ferramenta que mais se adequava ao seu metaobjetivo de rápido crescimento econômico" (REISMAN, 1998, p. 357). Este pragmatismo, que se distancia muito da moralidade de virtudes defendida na TMS, se apresenta na própria definição do papel do Estado em Smith: defesa; justiça; e obras ou instituições públicas (SMITH, 1961 [1776], p. 690, p. 709, p. 723). Enquanto tanto defesa externa e justiça ambas são atribuições que podem ser categorizadas dentro do campo da virtude da "justiça" na TMS (impede que mal seja causado aos demais), não é evidente que a manutenção de bens públicos por parte do Estado possui a mesma característica. Afinal, não há um mal positivo que é causado pela ausência de um bem público. Em suma, as possibilidades de ação do Estado na WN são tão dispares das apresentadas na TMS, que não é completamente impossível que o sistema de liberdade natural de Smith na WN permitisse uma instituição pública, artificial, que resolvesse adequadamente o problema da pobreza extrema. A especulação baseada no silêncio de Smith encontra alguma base, pois, não seria correto afirmar que o autor não se preocupasse com a condição de pobreza absoluta: 
No society can surely be flourishing and happy, of which the far greater part of the members are poor and miserable. It is but equity, besides, that they who feed, cloath and lodge the whole body of the people, should have such a share of the produce of their own labour as to be themselves tolerably well fed, cloathed and lodged (SMITH, 1979 [1776], p. 96).

Assim, a transição observada nas obras de Smith quanto à perfectibilidade da ordem natural na TMS e, posteriormente, a imperfectibilidade da mesma na $\mathrm{WN}$, tornaria admissível a interpretação que instituições artificiais seriam em geral rejeitadas na primeira obra, ao passo que as mesmas podem, em casos específicos, serem aceitas como soluções pragmáticas às falhas de mercado. Seria a Lei dos Pobres uma destas soluções ao problema da miséria na Inglaterra?

O quadro geral de enormes obstáculos à caridade privada poderia levar a esperar uma posição, por parte de Smith, de maior flexibilidade no papel do Estado em relação à Lei dos Pobres e outros esquemas públicos de alívio à pobreza. Contudo, como já foi mencionado, enquanto na TMS há uma predominância de argumentos que rejeitariam estas políticas, na WN Smith é "estranhamente silencioso" nesta questão (GILBERT, 1997), apenas criticando as "laws of settlements" 24 em um contexto de condenação à imobilidade do trabalho que estas leis causariam. A própria ausência de argumentos diretamente relacionados ao auxílio em si exige alguma investigação.

A ausência de um argumento específico quanto ao auxílio aos pobres em Smith reflete justamente a falta de preocupação do autor com a necessidade de encontrar uma solução exterior às forças de livre mercado para esta questão. Isto é, se é verdade que existem muitos obstáculos à realização da caridade voluntária e, que, em geral o mercado é uma instituição que tende a reduzir a oferta de doações, também é verdade que a necessidade real de auxílio é drasticamente reduzida na medida em que a sociedade como um todo se enriquece através da livre iniciativa alimentada pela busca auto interessada pela riqueza. Ao contrário do que defende Birch (1998), não haveria necessariamente uma deficiência por caridade que justificaria uma intervenção do Estado neste caso. Tanto parece ser verdade esta interpretação, de que Smith não está particularmente preocupado com o auxílio, mas apenas com o bom funcionamento do livre mercado, que os únicos trechos em que se discute especificamente a Lei dos Pobres, o autor critica os elementos da lei que impedem a mobilidade de trabalho, que restringem o livre mercado (nem comentando o aspecto relacionado ao auxílio propriamente dito):

\footnotetext{
${ }^{24}$ A Lei dos Pobres, complementada e transformada nas Settlement Laws, justamente pela necessidade de obter certificação para mudar-se para outra paróquia (fazendo com que cada paróquia se torna-se responsável pelos seus pobres).
} 
The obstruction which corporation laws give to the free circulation of labour is common, I believe, to every part of Europe. That which is given to it by the poor laws, so far as I know, peculiar to England. It consists in the difficulty which a poor man finds in obtaining a settlement, or even in being allowed to exercise his industry in any parish but that to which he belongs (SMITH, 1979 [1776], p. 152).

Segundo Smith, os requerimentos necessários para que o trabalhador comum obtivesse um certificado que garantisse a sua não expulsão ao se mudar de paróquia, tornavam efetivamente impraticável se mudar em busca de oportunidades de trabalho em outras paróquias. Consequentemente enormes disparidades de salários e desequilíbrios de oferta e demanda de mão de obra eram observadas na Inglaterra. A rejeição da Lei dos Pobres, por Smith, não é contingente à questão do auxílio em si, mas sim aos entraves que esta causava ao sistema econômico e à liberdade do trabalhador:

Let the same natural liberty of exercising what species of industry they please be restored to all his majesty's subjects, in the same manner as to soldiers and seamen; that is, break down the exclusive privileges of corporations, and repeal the statute of apprenticeship, both which are real encroachments upon natural liberty, and add to these the repeal of the law of settlements, so that a poor workman, when thrown out of employment either in one trade or in one place, may seek for it in another trade or in another place, without the fear either of a prosecution or of a removal (SMITH, 1979 [1776], p. 470)

É verdade que Smith pede, claramente, a abolição da Lei dos Pobres (a qual Smith se refere como "law of settlements"), entretanto (ao contrário de Malthus, como veremos adiante), ele não descreve todos os elementos da lei e nem como a abolição deveria ser realizada, muito menos o que se colocaria em seu lugar. É possível imaginar que uma reforma cuidadosa da legislação poderia manter a peça fundamental do auxílio, e, ao mesmo tempo, remover os impedimentos à mobilidade de trabalho que são a base do argumento de Smith contra o Settlement act. Em particular, a centralização do esquema parece ser uma solução bastante direta para esta questão específica das restrições à mobilidade do trabalho (ainda que possivelmente cause outras distorções artificiais às quais Smith poderia levantar objeção). Assim, sem tomar o caminho nem de Malthus (que expressará clareza quanto à necessidade de abolição de todos aspectos da Lei dos Pobres), nem de Bentham (que expressará a necessidade de uma expansão e reforma radical da Lei para seu funcionamento adequado), Smith demonstra sua falta de preocupação com o tema.

Além de instituições como a Lei dos Pobres, diretamente relacionadas ao auxílio público à pobreza, existiriam outras instituições relevantes ao tema da caridade que merecem atenção no sistema de Smith? Ao menos duas podem ser citadas e analisadas a seguir: o mercado e o sistema educacional. 


\subsection{O mercado, a escola e a caridade}

A articulação entre instituições e as divergências na ordem natural apresentadas na TMS versus WN, quando direcionada ao tema da caridade, leva a discussão da principal instituição na obra de Smith: o mercado propriamente dito, isto é, a organização de uma sociedade comercial ${ }^{25}$. Os efeitos do mercado sobre a caridade se dariam tanto de modo direto (afetando a oferta e demanda por caridade), como de modo indireto, através do efeito desta instituição sobre sentimentos benevolentes dos indivíduos. Comecemos por este último caso.

Na TMS, Smith menciona a "corrupção dos nossos sentimentos morais" (SMITH, 1984 [1759], p. 61), demonstrando uma certa preocupação com excessos que apenas a opulência de uma sociedade comercial poderia ocasionar. Esta "corrupção dos sentimentos morais" na TMS aparece como a tendência excessiva em valorizar acumulação material e ostentação de riquezas, simultânea a uma falta de atenção aos pobres. Adicionalmente, como argumenta Birch (1998), há na WN indícios de que Smith observava obstáculos à caridade decorrentes da presença de um mercado desenvolvido (BIRCH, 1998, p. 34-36). Entre os obstáculos podem ser listados uma corrosão do nosso autocomando, devido ao próprio conforto gerado pela condição de prosperidade econômica. Outro obstáculo está relacionado aos efeitos nocivos da especialização em trabalhos braçais. Smith explica que a repetição excessiva de funções simples leva o homem a um "torpor mental" e impede a concepção de "qualquer sentimento generoso, nobre ou sensível” (SMITH, 1976 [1776], p. 781-782). Apesar deste trecho não estar tratando de caridade, uma implicação da ausência de sentimentos generosos causada por esta condição do trabalhador na sociedade comercial é a redução da virtude da benevolência. Assim, tais distorções apontadas por Birch (1998) que Smith destaca em uma sociedade comercial tendem a reduzir a oferta de caridade, uma vez que as virtudes da benevolência e autocomando, essenciais à caridade, são prejudicadas ${ }^{26}$. Esta seria uma conclusão que é compatível, inclusive, com o contexto histórico de redução da influência da Igreja e da nobreza (cujo a legitimidade estaria em parte conectada com o sustento dos pobres), para concessão de espaço ao mercado e ao Estado.

\footnotetext{
${ }^{25}$ Há ainda uma complicação adicional ao se discutir esta questão: na obra de Smith, a distinção entre "ordem natural" (incluindo a natureza humana) e "instituições" não é sempre direta, sendo em alguns casos inexistente. Isto é, certas instituições humanas podem ser consideradas parte da ordem natural (como o livre mercado), enquanto outras (como as Settlement Laws) não. Não há necessariamente aqui uma contraposição entre instituições e ordem natural.

${ }^{26}$ Maitland (1997), por outro lado, argumenta que, em geral, as virtudes da prudência e da justiça são amplamente beneficiadas pelo sistema competitivo.
} 
Por outro lado, certamente os efeitos do mercado sobre a demanda de caridade são de reduzi-la, balanceando (ou mesmo superando) aqueles que reduzem a oferta de caridade. A capacidade de uma sociedade comercial de gerar riquezas para todos seus participantes teria uma tendência clara de reduzir a miséria, e, portanto, reduzir a necessidade aguda de auxílio aos mais pobres. Uma vez que há a tendência de que a prudência seja impulsionada em uma sociedade comercial, bem como a justiça garantida, a demanda por caridade diminuiria. Há na WN uma crença clara de que a difusão de riquezas chegaria aos mais pobres através da divisão do trabalho em uma sociedade comercial:

It is the great multiplication of the productions of all the different arts, in consequence of the division of labour, which occasions, in a wellgoverned society, that universal opulence which extends itself to the lowest ranks of the people (SMITH, 1976 [1776], p. 22).

E, por fim, uma última instituição que é relevante à discussão da caridade é a educação, em um sentindo amplo da palavra, educação informal e formal. Retomando a TMS, a diferenciação entre instituições que surgem da própria ordem natural versus aquelas que surgem artificialmente, é novamente relevante - Smith ataca o hábito de algumas famílias de enviar filhos e filhas para estudar em grandes escolas distantes, morando fora de casa, e, portanto, tornando ausente a educação familiar que naturalmente ocorreria:

Do you wish to educate your children to be dutiful to their parents, to be kind and affectionate to their brothers and sisters? Put them under the necessity of being dutiful children, of being kind and affectionate brothers and sisters: educate them in your own house (SMITH, 1979 [1759], p. 222).

Isto não significa que Smith fosse contra educação formal em si, é apenas a completa ausência familiar na educação dos filhos que está sendo criticada neste trecho. Ainda assim, a razão pela qual Smith prefere a educação doméstica é direta e reforça a noção de perfectibilidade da ordem natural na TMS: “educação doméstica é a instituição da natureza; educação pública, um arranjo humano. É certamente desnecessário dizer, qual é mais provável de ser a mais sábia" (SMITH, 1979 [1759], p. 222). Note que, na argumentação de Smith, a educação está sendo destacada como um elemento formador de virtudes, especificamente de virtudes relacionadas ao autocomando ("dutiful") e à benevolência ("kind and affectionate"). Outros exemplos de como a instituição da educação pode ser instrumental na transmissão de virtudes são bastante explícitos na TMS, permitindo inclusive que uma pessoa virtuosamente educada possa agir de modo a superar suas próprias emoções (ou ausência delas): 
The man who has received great benefits from another person, may, by the natural coldness of his temper, feel but a very small degree of the sentiment of gratitude. If he has been virtuously educated, however, he will often have been made to observe how odious those actions appear which denote a want of this sentiment, and how amiable the contrary (SMITH, 1979 [1759], p. 162).

Ou ainda:

A wife, in the same manner, may sometimes not feel that tender regard for her husband which is suitable to the relation that subsists between them. If she has been virtuously educated, however, she will endeavour to act as if she felt it, to be careful, officious, faithful, and sincere, and to be deficient in none of those attentions which the sentiment of conjugal affection could have prompted her to perform (SMITH, 1979 [1759], p. 162)

Estes trechos são especialmente relevantes pois eles indicam, indiretamente, a possibilidade de realização de ações benevolentes na ausência da simpatia (aprovação, sem simpatia, mas com benevolência), contanto que o indivíduo em questão tenha tido uma educação capaz de torna-lo consciente de sua possível deficiência emocional.

Em conclusão, dada a complexa influência da psicologia e moral que Smith apresenta, é possível interpretar que o autor não dá espaço para interferência estatal no auxílio aos pobres dentro da TMS, e considera o tema desimportante na WN muito provavelmente devido a esperança de que uma sociedade comercial livre será capaz de eliminar casos de pobreza extrema. Esta sociedade comercial, apesar de reduzir a demanda de caridade, potencialmente reduz a oferta de caridade ao "corromper nossos sentimentos morais", em especial aqueles conectados à benevolência e ao auto interesse. Uma maneira de fortalecer estas virtudes, contudo, se daria através da educação.

No conjunto da obra, sobressai aquilo que é claro apenas na TMS: "o auxílio e consolação da miséria humana dependem totalmente de nossa compaixão pela mesma" (SMITH, p. 226, 1984 [1759]), seja qual fosse o posicionamento do "pai da economia clássica" quanto à presença do Estado nesta atividade de auxílio no momento em que escrevia sua obra mais famosa, é através do exercício de virtudes, amplificadas pelo autocomando, que a caridade pode ser exercida. Assim finaliza-se a análise de Smith quanto à caridade. A próxima seção trata de Malthus. 


\title{
3. O BANQUETE MALTHUSIANO
}

Inicia-se a análise do tema da caridade em Malthus a partir de um trecho específico de sua obra, o "banquete malthusiano", que permite a compreensão geral da concepção de benevolência do autor, e revela uma questão metodológica relevante ao assunto, diferenciando as primeiras e últimas edições de seu Essay on the Principle of Population ${ }^{27}$.

\subsection{Princípios gerais versus detalhes empíricos}

Na segunda edição do Essay, Malthus utiliza a metáfora de um grande banquete para exprimir suas preocupações com as consequências inevitáveis de um excesso de compaixão, em desafio direto às leis naturais:

\begin{abstract}
A man who is born into a world already possessed, if he cannot get subsistence from his parents on whom he has a just demand, and if the society do not want his labour, has no claim of right to the smallest portion of food, and, in fact, has no business to be where he is. At nature's mighty feast there is no vacant cover for him. She tells him to be gone, and will quickly execute her own orders, if he does not work upon the compassion of some of her guests. If these guests get up and make room for him, other intruders immediately appear demanding the same favour. The report of a provision for all that come, fills the hall with numerous claimants. The order and harmony of the feast is disturbed, the plenty that before reigned is changed into scarcity; and the happiness of the guests is destroyed by the spectacle of misery and dependence in every part of the hall, and by the clamorous importunity of those, who are justly enraged at not finding the provision which they had been taught to expect. The guests learn too late their error, in counter-acting those strict orders to all intruders, issued by the great mistress of the feast, who, wishing that all guests should have plenty, and knowing she could not provide for unlimited numbers, humanely refused to admit fresh comers when her table was already full (MALTHUS apud HARDIN, 1998 [1803], p. 181).
\end{abstract}

Este importante trecho (que será analisado na seção seguinte) representa adequadamente a visão de mundo propriamente malthusiana, e, ainda assim, como destacou habilmente Hardin (1998) em seu artigo dedicado especificamente a este trecho, é apenas na segunda, e em nenhuma edição posterior, que a metáfora do banquete foi utilizada por Malthus. É de fato, frustrante, que o trecho tenha sido removido da obra, pois como destaca Hardin sobre o "banquete": "Se Malthus tivesse mantido este parágrafo e justificado-o adequadamente nas

27 Doravante "Essay". 
edições seguintes, eu acredito que teríamos sido poupados de quase duzentos anos de rixas improdutivas" (HARDIN, 1998, p. 181).

A remoção deste trecho representa uma mudança de método e estilo na obra que altera a interpretação do leitor. Enquanto a primeira edição do Essay é muito baseada em fortes premissas quanto ao comportamento humano e leis sociais rígidas, essencialmente partindo do que podemos chamar de "natural", para chegar em conclusões inevitáveis e generalizadas, as últimas edições possuem um caráter preponderantemente empírico, descritivo. Na medida em que as edições avançam, a obra adere cada vez mais a esta tendência. A última, como próprio Malthus destacou, "pode ser considerada uma nova obra” (MALTHUS, 1826, Livro I, p. v-vi). Aparentemente, os exageros nas conclusões da primeira edição, apontados por comentadores, influenciaram de tal modo Malthus, que o autor acabou por diluir o destaque às suas ideias essenciais para demonstrá-las empiricamente e torná-las menos absolutas. Segundo Winch, é já a partir da segunda edição em diante que a obra se altera com o foco em ilustrar o princípio da população, e revisar suas consequências: “As alterações feitas a partir da segunda edição do Essay, no período entre 1803 e 1826, fornecem um comentário corrrente no desenvolvimento intelectual de Malthus; elas incorporam suas respostas aos seus numerosos críticos" (WINCH, 1987, p. 36). E ao fazê-lo, apesar de obter maior precisão acadêmica, reduziu-se o destaque anteriormente dado ao núcleo de seu trabalho, dissolvendo-o em uma obra muito mais extensa.

Apesar desse contraste entre as edições, contudo, há uma continuidade na obra do autor. A introdução do "freio moral" e as diversas maneiras de regular a natureza humana que surgem com a publicação de edições adicionais representam a inclusão da ideia de que o homem possui a capacidade de desenvolver-se para agir com prudência, autocontrole, o que Malthus não havia completamente levado em conta na primeira edição. Ainda que este comportamento fosse possível apenas em circunstâncias específicas, o exercício destas virtudes não anula a grande visão de fortes leis naturais. Na sexta edição, há uma abundância de detalhes empíricos historicamente relevantes, mas que apresentam-se mais como demonstrações em resposta à dura reação pública, destacada por Hardin (1998, p. 182) e por Petersen (1990, p. 276), do que o desenvolvimento de muitas ideias novas relevantes ao pensamento econômico ${ }^{28}$. Desta forma, é importante destacar que é o foco em princípios e consequências elaborados por Malthus e não

\footnotetext{
${ }^{28}$ Em relação à metáfora do "banquete", por exemplo, Hardin destaca que: "Malthus was hurt by the reactions to his moving metaphor" (HARDIN, 1998, p. 182); "Nas palavras de Shelley, Malthus seria um 'eunuco e tirano' e 'o apóstolo dos ricos"” (PETERSEN, 1990, p. 276). Entre outros que o criticaram duramente estariam inclusos Byron, Coleridge, Robert Southey, William Hazlitt e William Cobbett, nomes influentes no ambiente intelectual inglês da virada do século (PETERSEN, 1990, p. 276-277). Não que as observações empíricas realizadas por Malthus sejam de pouco valor. Há muito que se confirma e se altera devido as viagens e dados coletados pelo autor. Contudo, o conteúdo teórico (isto é, a apresentação de ideias) é muito diluído nos capítulos empíricos.
} 
detalhes empíricos, que será adotado no presente trabalho para compreender como sua visão de natureza humana influenciou suas conclusões gerais quanto à caridade e a Lei dos Pobres. Salvo prévio aviso, a literatura primária é, portanto, baseada nos capítulos teóricos da sexta edição (Livros III e IV), que incluem os principais conceitos herdados desde a primeira edição e refinados pelas observações empíricas (dos Livros I e II).

\title{
3.2. Desmembrando o "banquete da natureza" malthusiano
}

A metáfora do banquete é bastante útil para compreender uma das crenças básicas no pensamento conservador de Malthus. Primeiramente: por natureza, indivíduos se encontram em situação desigual. Mais que isso, boa parte deles são eliminados pela situação de escassez em que se encontram. Esta é a condição normal, esperada, "natural" do homem em sociedade. A admissão desta situação não implica, inicialmente, em um aval deste sofrimento. No início da primeira edição, Malthus admite que gostaria sim de estar errado, gostaria que os esquemas utópicos fossem viáveis:

\begin{abstract}
I have read some of the speculations on the perfectibility of man and of society with great pleasure. I have been warmed and delighted with the enchanting picture which they hold forth. I ardently wish for such happy improvements. But I see great, and, to my understanding, unconquerable difficulties in the way to them. These difficulties it is my present purpose to state, declaring, at the same time, that so far from exulting in them, as a cause of triumph over the friends of innovation, nothing would give me greater pleasure than to see them completely removed (MALTHUS, 1998 [1798], p. 3).
\end{abstract}

É importante entender, portanto, que um significado mais profundo da tese malthusiana é a necessidade de uma atitude realista. $\mathrm{O}$ ataque às propostas de caráter igualitário, que incluí esquemas como uma mais relaxada Lei dos Pobres, ou redistribuições ainda mais radicais, representam não uma condenação ao resultado prometido pelos seus proponentes - que seria excelente de acordo com Malthus - mas sim ao resultado efetivo que elas causariam. Qualquer busca pela maior "perfectibilidade do homem e sociedade", deve ser calcada na realidade, levando em conta a natureza humana, e, portanto, cuidadosa, de caráter cético e conservador.

No "banquete" da natureza, por exemplo, é possível que aqueles que foram excluídos consigam evocar a "compaixão dos convidados". São tantos os excluídos por natureza, contudo, que o mero sinal de compaixão atrai tantos com quem compartilhar o banquete que a abundância dos poucos privilegiados se transforma em uma escassez generalizada. A conclusão 
de Malthus é inevitável: o caminho mais "humano" é respeitar a natureza e manter excluídos aqueles que não tinham lugar à mesa.

É necessário portanto identificar: (i) como esta visão de mundo se encaixa na moral proposta por Malthus, descrita como uma "utilitarismo teológico" (WINCH, 1987, p. 37); (ii) quem são os convidados e os excluídos do banquete da natureza, e o que determina estas posições; (iii) tendo em mente os limites impostos pela natureza, qual é o papel das instituições? (iv) qual é o argumento detalhado para conclusão de que um desafio à natureza através da compaixão está fadado ao fracasso - mais especificamente, como a Lei dos Pobres e caridade indiscriminada não melhoram a condição do homem; (v) sob que circunstâncias existem exceções a esta conclusão, e como exercer compaixão nestes casos (caridade discriminada). Cada um destes pontos é fundamentalmente pautado pela visão de natureza humana do autor.

\subsection{Utilitarismo teológico}

Ao longo do Essay, uma estrutura ética é construída para compreender algumas das posições de Malthus, o que pode ser chamado de "utilitarismo teológico"29. Talvez a principal característica desta estrutura é a compatibilização da naturalidade do sofrimento humano com a simultânea satisfação da vontade divina e felicidade do homem no futuro. Por exemplo, Malthus explica que doenças como a praga em cidades imundas e descuidadas são um sinal à humanidade que leis naturais foram ofendidas ou ignoradas, e portanto, o sofrimento dos habitantes desta cidade são nada mais que um aviso para que outros não sigam o mesmo caminho (MALTHUS, 1826, Livro IV, p. 258). Ausente qualquer punição pela falta de higiene e organização urbana, a humanidade seria ignorante de seus erros e não teria como corrigi-los. Young resume esta conciliação de sofrimento e progresso da seguinte maneira:

\footnotetext{
${ }^{29}$ O termo utilizado por Winch (1987) é "utilitarismo teológico" para descrever a doutrina ética de Malthus. Cresmaschi (2014, p. 195) indica que este termo foi muito utilizado por comentaristas, contudo, a falta de consenso quanto a utilização aparece do fato de que outro conjunto de pensadores do século XVIII, que incluí Paley, John Gay e Thomas Brown, foram categorizados pela mesma expressão, ao passo que Malthus não se encaixa na mesma categoria destes autores - tanto é o caso que Cremaschi prefere utilizar o termo mais obsucuro "voluntaristaconsequencialista" para descrever a doutrina de Malthus (CREMASCHI, 2013, p. 44). Aqui, contudo, aceita-se a visão de que a teologia de Malthus é baseada em um utilitarismo e adota-se a visão de que o termo "utilitarismo teológico" é adequado, mas ainda assim distinto do utilitarismo teológico de Paley.
} 
If this view gives, as he says 'a melancholy hue' to human life then this view must be explained and justified. It is explained in terms of the necessity for evil in order to produce exertion, exertion to produce mind, and mind to produce progress. (...) Man is sinful, inert, sluggish, and averse to labour, unless compelled by necessity (YOUNG, 1969, p. 117).

A própria noção de "vício" e "miséria", usada por Malthus em toda a obra, é uma noção que reflete a utilitarismo teológico - um ato é vicioso se este tende a gerar miséria, e, é portanto, proibido por Deus (MALTHUS, 1826, Livro I, p. 17). Note que esta estrutura permite exceções, como o próprio autor indica, é possível que um ato vicioso gere, ocasionalmente, felicidade. Ainda assim, é um ato proibido e que deve ser evitado, uma vez que sua tendência é gerar miséria. É possível, por exemplo, que ao apostar sua fortuna em um cassino, a sorte lhe ceda grande felicidade - ainda assim, a tendência em gerar miséria neste caso seria tão maior, que indulgenciar exageradamente em jogos de azar seria um vício sob a lente malthusiana. $\mathrm{O}$ ato de roubar comida para satisfazer a fome, por exemplo, é considerado vicioso devido as suas consequências, pois se este impulso natural não fosse prevenido pela lei, a quantidade de pão disponível diminuiria, reduzindo a utilidade geral (MALTHUS, 1826, Livro IV, p. 260). No caso, as consequências indicam que a instituição da propriedade privada é necessária para combater este vício que surge da natureza.

Fica claro que Malthus não adere à noção de que tudo que é natural é necessariamente bom, e que tudo que enfrenta a natureza é necessariamente um mal, mas sim que as leis naturais são onipresentes e precisam ser consideradas antes de qualquer decisão, e, portanto compreendidas. O respeito às leis naturais que nos beneficiam e o autocontrole para não ceder às que nos prejudicam são virtudes; o desrespeito àquelas que nos beneficiam ou a irresponsabilidade de seguir impulsos naturais que nos prejudicam são vícios. $\mathrm{E}$ as consequências destas escolhas mostram a vontade de Deus em cada caso, levando à felicidade ou ao sofrimento. O seguinte trecho destaca, por exemplo, vícios que surgem de impulsos naturais:

Natural and moral evil seem to be the instruments employed by the Deity in admonishing us to avoid any mode of conduct which is not suited to our being, and will consequently injure our happiness. If we are intemperate in eating and drinking, our health is disordered; if we indulge the transports of anger, we seldom fail to commit acts of which we afterwards repent; if we multiply too fast, we die miserably of poverty and contagious diseases (MALTHUS, 1826, Livro IV, p. 256).

E quanto as leis naturais e paixões humanas, Malthus destaca que há necessidade de agir de modo sábio levando-as em conta, "regulando-as": 
They [human passions, and all the general laws of nature] are, in fact, the materials of all our pleasures, as well as of all our pains; of all our happiness, as well as of all our misery; of all our virtues, as well as of all our vices. It must therefore be regulation and direction that are wanted, not diminution or extinction (MALTHUS, 1826, Livro IV, p. 265).

Assim, o entendimento adequado da estrutura ética proposta por Malthus é uma de convergência entre leis morais naturais e o utilitarismo tradicional. Ao impor padrões às consequências das ações humanas, leis naturais fazem com que o respeito ou desrespeito a certas regras morais rígidas levem a resultados utilitariamente positivos ou negativos, respectivamente. Em outras palavras, uma versão pura de utilitarismo, por si só, é incompleta se não levar em conta as consequências de leis naturais ${ }^{30}$. Aquilo que "maximiza a utilidade geral" só seria atingido seguindo regras naturais imutáveis, sendo ingênuo imaginar que o que maximiza a utilidade geral varia drasticamente caso a caso. As revelações religiosas, para Malthus, seriam portanto nada menos que a exposição explícita de regras que maximizam a utilidade geral. Alguns autores acusam Malthus de não ser "de modo algum um utilitarista" (SOWELL, 1962, p. 268). Esta interpretação, contudo, surge de uma intepretação estreita do que se define como "utilitarismo", pois mesmo Sowell, ao passar este julgamento, destaca que:

\begin{abstract}
Malthus was of course religious, while the Utilitarians were agnostics who made the welfare of man the standard of right and wrong. This, however, was not a source of practical differences, for Malthus pictured the ordinances of God as directed towards maximizing human happiness. (...) Malthus and the Utilitarians were agreed as to the efficient cause of the population problem, but with Malthus there was also a final cause - the value of adversity as a spur to exertion, in which the meaning of life is deepened (SOWELL, 1962, p. 269-270).
\end{abstract}

Assim, embora Sowell (1962) não considere Malthus um utilitarista, é evidente o reconhecimento de que Malthus está preocupado com as consequências distantes das ações humanas. Esta interpretação traz uma separação adicional entre a utilitarismo teológico malthusiana e o utilitarismo puro (prazer vs. dor), pois demonstra que Malthus não está levando em conta apenas algumas consequências hedônicas das ações humanas, mas também incluí na "utilidade" até mesmo a presença de um "sentido à vida" para as pessoas. A inexistência de obstáculos a serem superados, a ausência completa de sofrimento, que tanto utópicos como utilitaristas buscavam, eliminaria qualquer propósito maior que leva ao esforço humano.

\footnotetext{
${ }^{30}$ Comumente, encontram-se em campos opostos visões jusnaturalistas e utilitaristas de filosofia moral. Isto se deveria a suposta flexibilidade do utilitarismo que proporia um curso de ação adequado para cada situação, sendo a melhor aquela que maximize a utilidade geral. Ao mesmo tempo, uma visão moral baseada em leis naturais seria inflexível, independente das consequências relacionadas ao bem estar social. Em suma a visão de Malthus é basicamente a de que mesmo se usando o "teste da utilidade" (MALTHUS, 1826, Livro IV, p. 361) como princípio moral, a conclusão seria justamente o respeito às tradicionais leis morais naturais (sugeridas, no caso de Malthus, pela religião).
} 
É neste contexto, de busca pela maior utilidade geral (em um sentido extermamente amplo de utilidade), compreendendo não só o prazer e a dor que os impulsos humanos naturais podem trazer, mas também a necessidade de punições e recompensas baseadas nas leis naturais, que Malthus insere a importância do que ele denomina de "freio moral" - definido como o autocontrole necessário resistir um dos mais fortes impulsos naturais que seria paixão entre os sexos. O "freio moral", portanto, seria uma categoria bem vinda de controle preventivo ${ }^{31}$.

\subsection{Ricos e pobres}

Seria apenas o exercício de virtudes como o "freio moral" permitindo um casamento tardio que determinaria a posição dos ricos e dos pobres na sociedade? Claramente, Malthus faz esta conexão, e não hesita em afirmar que a posição social é ao menos parcialmente determinada por diferenças no comportamento dos indivíduos - alguns, mais merecedores de fortuna que outros. Expressões que categorizam certos indivíduos "mais industriosos e merecedores" (MALTHUS, 1826, Livro III, p. 82) que outros, demonstram esta visão de mundo.

Ainda assim, apesar de afirmar que a causa da pobreza é, em geral, o próprio comportamento do pobre, ele não os culpa de forma categórica. Malthus vê a grande massa dos pobres como pessoas que agem de modo irresponsável por ignorância, e não por escolha própria. Isto é, a falta de educação nas virtudes necessárias para o melhoramento da própria vida seria a principal causa da pobreza sistêmica (WINCH, 1989, p. 41). Seria necessário que as ideias de poupar, atrasar o casamento quando necessário, se esforçar no exercício do trabalho, entre outras virtudes, fossem promovidas afim de melhorar a condição do pobre:

[...] we cannot justly accuse them [the poor] of improvidence and want of industry, till they act as they do now, after it has been brought home to their comprehensions, that they are themselves the cause of their own poverty; that the means of redress are in their own hands, and in the hands of no other persons whatever ; that the society in which they live and the government which presides over it, are without any direct power in this respect (MALTHUS, 1826, Livro IV, p. 288);

\footnotetext{
${ }^{31}$ Outros controles preventivos, como métodos anticoncepcionais, formas "não naturais" de sexualidade ou aborto, seriam vícios na visão malthusiana, uma vez que, apesar de serem capazes de reduzir as pressões populacionais, levariam (via de regra) a consequências negativas no longo prazo ao violar a vontade de Deus.
} 
Seria um erro, contudo, assumir, que para Malthus não havia nenhum grau de arbitrariedade nesta divisão entre pessoas ricas e pobres. Embora fosse verdade que a perpetuação da pobreza estivesse ligada às ações das próprias pessoas pobres, pode-se dizer que suas dotações iniciais e sua falta de instrução desde o nascimento seriam frutos de uma verdadeira "loteria da vida":

It has appeared that from the inevitable laws of human nature some human beings will be exposed to want. These are the unhappy persons, who in the great lottery of life have drawn a blank (MALTHUS, 1826, Livro III, p. 34).

Note que a expressão "loteria" indica uma perspectiva que alguns considerariram supreendente na obra de Malthus - não há indício de que o autor defenda que as vagas para o banquete são determinadas pelo fato de que algumas pessoas seriam naturalmente mais deficientes que outras - mas sim por azar. Isto é, a "culpa" do pobre de ser pobre é uma conclusão que só se sustenta na medida em que são as ações do pobre que perpetuam sua pobreza, contudo, os condicionantes destas ações, são essencialmente arbitrariamente distribuídos no nascimento. Adicionalmente, Malthus não chega a discutir se existiria mobilidade social suficiente (SIMONS, 1955, p. 67), contudo, é implícito que a mobilidade social não seria limitada pela falta de liberdade, mas sim pela falta de instrução ou fibra moral.

\subsection{Princípio da população e a natureza humana}

Não há na obra de Malthus uma seção dedicada especificamente à investigação da natureza humana, ainda assim o conceito permeia uma vasta gama de proposições do autor. Como Cremaschi (2014, p. 41-43) destaca, não há pretensão declarada em discutir filosoficamente, por exemplo, o que constitui "felicidade" para o homem. Todos aspectos relacionados ao comportamento esperado do indivíduo em sociedade, do que é virtuoso e vicioso e o quão relevante é a natureza em comparação às instituições, são encontrados em contextos diferentes nas argumentações de Malthus. Mesmo assim, o próprio "Princípio da População", em suas premissas, carrega enorme peso explicativo da visão malthusiana do homem, que é fortemente influenciada por noções biológicas, sendo reforçado ao longo do resto da obra. 
Como Malthus expõe na primeira edição (e mantendo até última), o seu Princípio possui dois postulados centrais:

I think I may fairly make two postulata. First, that food is necessary to the existence of man. Secondly, that the passion between the sexes is necessary and will remain nearly in its present state (MALTHUS, 1998 [1798], p. 4).

Não é sem razão que tanto Darwin como Wallace teriam sido diretamente influenciados por Malthus ao desenvolver a teoria evolucionária baseada em seleção natural (HERBERT, $1971)^{32}$. O primeiro postulado apresentado é a observação de que a busca pela sobrevivência, é fundamental para a existência do homem. O segundo, que a reprodução também o é. Malthus não chega a conectar esta proposição com o raciocínio que constituí a teoria evolucionaria darwinista, de que são as adaptações relacionadas à sobrevivência e reprodução que moldam a constituição das espécies na Terra através de um processo de seleção - um processo de competição nestes dois aspectos fundamentais (BOWLER, 1976, p. 634). Ainda assim, pulando esta etapa, fica claro que Malthus chega a uma conclusão que Darwin também chegaria, a de que o comportamento das espécies, incluindo o homem, é em grande parte determinado por estes dois postulados principais - a natureza humana seria moldada por paixões e ações que favorecem a sobrevivência e a reprodução, que Darwin denominava de "seleção natural" e “seleção sexual”, respectivamente (DARWIN, 1981 [1871], p. viii). Em uma obra clássica de Darwin, The Descent of Man, por exemplo, é realizada a observação de que é a partir dessas duas pressões evolucionárias que se compreende várias características mentais do homem e sob que circunstâncias quais se manifestam com maior intensidade.

Malthus ao atacar esquemas sociais utópicos, frequentemente desconstrói as propostas até chegar nas consequências inevitáveis do Princípio da População: que a reprodução humana será acelerada em condições de abundância e que a luta pela sobrevivência guiará o comportamento em sociedade em condições de escassez. São premissas que ele mesmo reconhece que valem não apenas para o homem, mas para todos animais (MALTHUS, 1998

\footnotetext{
${ }^{32}$ Sobre o Essay, Wallace afirma: "Foi o primeiro trabalho que eu li até então tratando de qualquer problema que seja de filosofia biológica, e seus princípios centrais se mantiveram comigo permanentemente, e vinte anos depois me forneceram a muito buscada pista sobre o agente efetivo na evolução das espécies orgânicas" (WALLACE apud BOWEN, 1930); Também sobre o Essay, Darwin expressa: "Em outbro, 1838, isto é, quinze meses depois que eu iniciei minha investigação sistemática, eu por acaso li a fim de entreterimento Malthus em seu Ensaio sobre a população, e estando bem preparado para apreciar a competição pela existência que em toda a parte acontece... percebi que sob aquelas circunstâncias, variações favoráveis tenderiam a ser preservadas e desfavoráveis destruídas. O resultado seria a formação de uma nova espécie. Aqui, então, eu finalmente tinha uma teoria com a qual trabalhar" (DARWIN apud BOWEN, 1930).
} 
[1798], p. 5), sendo essencialmente biológicas. Para um estudioso do tema, a conexão é tão clara que o debate sócio-econômico relacionado à natureza humana se torna inseparável da biologia:

\begin{abstract}
In a sense I want to marry history of socio-economic theory and history of biology or to alter the metaphor - to show that Malthus, Paley, Chalmers, Darwin, Charles Lyell, Herbert Spencer, A. R. Wallace and others were part of a single debate. (...) the distinction between man and animals which evolutionary theory was supposed to break down from 1859 onwards - was broken down in principle well before the turn of the century. (...) From this point of view then, Malthus was a biologist, a human ecologist (YOUNG, 1969, p. 110-111).
\end{abstract}

Assim, tendo em mente o quão fundamental são as leis naturais para entender o homem sob uma lente malthusiana, é necessário buscar quais são, exatamente, as consequências comportamentais destas pressões relacionadas à reprodução e sobrevivência. Uma das observações mais claras, já discutida na seção tratando da utilitarismo teológico é a "lei da necessidade", ou seja, a tendência do homem em se esforçar para produzir riqueza apenas quando for necessário para sua sobrevivência, ou para a sobrevivência de sua família. Um dos efeitos da Lei dos Pobres, portanto, seria exatamente a ilusão de segurança econômica, e a consequente redução dos esforços dos trabalhadores.

A ideia de que uma situação confortável gera comportamentos irresponsáveis (como despoupança, promiscuídade e preguiça) na grande maioria das pessoas pode ser considerada uma "lei" da natureza humana mais geral no sistema malthusiano. Note que, ao chegar na sexta edição, Malthus não trata esta "lei" como uma inevitabilidade para todas as pessoas, mas sim como uma lei no sentido em que há uma tentação a ceder a comportamentos irresponsáveis uma vez que uma condição de conforto se estabelece - e, portanto, no agregado, é correto esperar que uma parcela significativa da população ceda a estas tentações, em especial as pessoas que já se encontravam em dificuldades devido a outros comportamentos irresponsáveis.

Além da redução do esforço, um segundo comportamento irresponsável que Malthus destaca como consequência deste conforto ilusório fornecido por esquemas como a Lei dos Pobres seria a tendência a acelerar o casamento, em linguagem plena, ter filhos mais cedo (MALTHUS, 1826, Livro III, p. 87-88). Este instinto é mais facilmente interrompido pela razão quando há dúvidas quanto à subsistência própria e de seus futuros filhos:

\footnotetext{
Impelled to the increase of his species by an equally powerful instinct, reason interrupts his career and asks him whether he may not bring beings into the world for whom he cannot provide the means of subsistence (MALTHUS, 1826, Livro I, p. 3).
}

Ainda assim é um "decreto da natureza uma conexão jovem à uma mulher" (MALTHUS, 1826, p. 4-5). A tese geral de Malthus contra a Lei dos Pobres e caridade indiscriminada é a de que tais instituições colocam os homens em uma situação em que o 
poderoso instinto de sobrevivência é relaxado, enquanto o de reprodução é exacerbado. Contudo, apesar de destacar estes dois aspectos como centrais, existem possibilidades que permitem escapar deste determinismo: comportamentos virtuosos, incluindo o desenvolvimento do "freio moral".

\subsection{Instituições e natureza humana}

Nesta seção são explorados os aspectos institucionais na teoria de Malthus. A seção foi dividida em quatro partes. Primeiro, é analisada a crítica de Malthus à Godwin e Condorcet, que explicita sua atitude de ceticismo quanto ao papel das instituições na transformação do comportamento do homem; em seguida, confronta-se "nature e nurture" na visão malthusiana; depois, as Leis dos Pobres são tratadas especificamente, e, finalizando a seção, são apresentadas as condições institucionais para o desenvolvimento do freio moral.

\subsubsection{Crítica aos "utópicos" Godwin e Condorcet}

Uma introdução à discussão do papel limitado das instituições frente à natureza humana é realizada quando Malthus se dá ao trabalho de atacar o que ele denomina de "sistemas de igualdade" de alguns autores, Condorcet e Godwin mais especificamente. Os capítulos são evidência adicional da preocupação central de Malthus de refutar os méritos de qualquer proposta que desafie a desigualdade natural e inevitável das sociedades. Ao realizar esta tarefa, são revelados importantes conceitos e esclarecimentos sobre o pensamento do autor em relação a certas leis naturais, além de tratar diretamente do tema de assistência governamental aos pobres e caridade privada.

Uma interpretação vulgar e errônea comum da teoria da população malthusiana costuma tomar a forma de que os limites físicos da Terra serão incapazes de sustentar uma população crescente. Segundo Malthus, alguns autores consideram sua teoria errônea, pois a Terra estaria muito distante de ter toda sua superfície cultivada para produção de alimentos. Malthus esclarece que não é o potencial de cultivo que realmente importa e sim a pequena velocidade 
efetiva da produção de alimentos em relação ao crescimento populacional (MALTHUS, 1826, Livro III, p. 2).

Segundo Malthus, Condorcet adota este argumento "vulgar", de que a extensão de terra fértil disponível para cultivo é demasiadamente ampla, e, portanto este momento de restrição natural ao crescimento da produção de alimentos estaria muito distante. Esta interpretação das preocupações com super-população estarem relacionadas a um limite distante de utilização dos recursos terrestres não adequa-se à estrutura do argumento malthusiano. Os limites naturais, para Malthus, são consistentemente presentes na sociedade, e não um alerta para um possível futuro em que a população cresce acima da capacidade potencial da produção de meios de subsistência (o que seria impossível) ${ }^{33}$. O princípio da população seria onipresente nas sociedades humanas:

[...] this constantly subsisting cause of periodical misery, has existed in most countries ever since we have had any histories of mankind, and continues to exist at the present moment (MALTHUS, 1826, Livro III, p. 7).

Após rapidamente lidar com esta objeção, Malthus responde às ideias mais radicais de Condorcet. A proposição do pensador francês é a criação de um fundo nacional que garanta a subsistência do idoso, de viúvas, órfãos e forneça crédito aqueles que estão começando uma família (MALTHUS, 1826, Livro III, p. 3-4). Basicamente um sistema de pensões, crédito e previdência. A primeira objeção de Malthus é a mais simples e direta: não haveria incentivo ao trabalho uma vez removida a necessidade de realizá-lo:

\begin{abstract}
If by establishments upon the plans that have been mentioned, this spur to industry be removed; if the idle and negligent be placed upon the same footing with regard to their credit and the future support of their wives and families, as the active and industrious; can we expect to see men exert that animated activity in bettering their condition, which now forms the master-spring of public prosperity? (MALTHUS, 1826, Livro III, p. 5).
\end{abstract}

A segunda objeção de Malthus, naturalmente, é a própria dinâmica do princípio da população. Afinal, um incentivo na forma de crédito para qualquer individuo disposto a começar uma família aceleraria muito o crescimento populacional, gerando o vício ou miséria decorrentes da escassez dos meios de subsistência.

Malthus vê Condorcet como um sonhador absolutamente fora dos parâmetros da realidade. Não é apenas o otimismo utópico quanto a melhoria social que incomoda Malthus, mas principalmente a crença de que a natureza humana é extremamente flexível. Condorcet

\footnotetext{
${ }^{33}$ Isto é, Malthus está preocupado com o excesso de população em relação à produção efetiva (em todos instantes) de alimentos, e não em comparação com a produção potencial que o planeta pode sustentar.
} 
afirma que os avanços no conhecimento, na área da saúde, na qualidade dos alimentos, no modo de viver seriam tamanhos que quaisquer preocupações com excessos de população e miséria deixariam de existir, que a expectativa de vida aumentaria indefinidamente, e que este progresso seria uma tendência geral. Para Malthus, o progresso seria possível apenas na medida em que atos virtuosos fossem praticados, sendo o regresso social certamente consequência de vícios (MALHTUS, 1826, p. 9). Se Condorcet estivesse certo, se a natureza humana fosse tão flexível ${ }^{34}$ quanto se supõe em seus esquemas utópicos:

\begin{abstract}
We may shut our eyes to the book of nature, as it will no longer be of any use to read it. The wildest and most improbable conjectures may be advanced with as much certainty, as the most just and sublime theories, founded on careful and reiterated experiments. We may return again to the old mode of philosophizing, and make facts bend to systems, instead of establishing systems upon facts (MALTHUS, 1826, Livro III, p. 10).
\end{abstract}

E concluí:

The constancy of the laws of nature, and of effects and causes, is the foundation of all human knowledge (MALTHUS, 1826, Livro III, p. 10).

É curioso notar que muitas das conjecturas e propostas de Condorcet vieram a se tornar realidade - como as pensões para idosos e assistência social para órfãos - mas não todas. Há nesta interação entre os dois autores uma dinâmica entre a visão de mundo progressista, idealista (de Condorcet) que propõe mudanças radicais para o avanço social, e a visão conservadora (de Malthus) que tem o papel de filtrar ideias inadequadas. Enquanto o primeiro entende leis naturais como muito flexíveis ou até mesmo inexistentes, facilmente superadas pela engenhosidade humana, o segundo as vê como essenciais para o entendimento do mundo, fortes, e meritórias de nosso respeito, sendo mais sábio estruturar a sociedade em harmonia com elas e não em contradição.

A visão de Godwin chama ainda mais atenção de Malthus, por não invocar o uso de força do governo para garantir uma utopia igualitária. Como descreve Malthus em um trecho que já adianta sua preferência pela caridade privada vis-à-vis intervenção estatal:

The unlimited exercise of private judgment is a doctrine grand and captivating, and has a vast superiority over those systems, where every individual is in a manner the slave of the public. The substitution of benevolence, as the master-spring and moving

\footnotetext{
${ }^{34}$ Note que a rigidez da natureza humana, para Malthus, é apenas uma manifestação do fato de que as leis naturais de modo geral são rígidas. A descoberta das leis da física por exemplo, inspiram em Malthus uma epistemologia em que necessariamente as observações da natureza fornecem a base para o desenvolvimento da teoria. Esta realidade não seria diferente nas ciências sociais, sob a lente malthusiana, o homem nada mais é que parte integral da natureza, e, portanto, a metodologia não deve diverger fundamentalmente. Suas premissas, no princípio da população, são manifestamente empíricas (WINCH, 1987).
} 
principle of society, instead of self-love, appears at first sight to be a consummation devoutly to be wished (MALTHUS, 1826, Livro III, p. 19).

Estes esquemas dependentes de uma benevolência voluntária extraordinária, que propõe uma verdadeira alteração na natureza humana, seriam bastante especulativos na visão malthusiana. Na descrição de um comentarista:

In the writings of Condorcet and Godwin, Utopian speculation had reached a stage which contemplated indefinite progress toward the complete absence of struggle among men: no illness, no sexual urge, no cares" (YOUNG, 1969, p. 112).

Mas é apenas “à primeira vista” que este sistema é desejável, ou sequer possível. Como afirma Young (1969, p. 112): "Godwin teria ido longe demais removendo o homem da natureza". Novamente, se colocando na posição de um realista, Malthus caracteriza a visão de Godwin como apenas um "fantasma da imaginação" (MALTHUS, 1826, Livro III, p.19). Assim como em sua refutação de Condorcet, Malthus reforça a importância das leis naturais. Contudo, desta vez, um importante aspecto é destacado: os vícios e o consequentes males que permeiam a sociedade são preponderantemente conectados com paixões humanas naturais. A natureza do homem é essencialmente imperfeita na visão malthusiana, e imutável. Enquanto para Godwin os males sociais são inteiramente consequentes de instituições inadequadas, Malthus as vê como parte pequena de um problema muito mais amplo.

The great error under which Mr. Godwin labours throughout his whole work is, the attributing of almost all the vices and misery that prevail in civil society to human institutions. But the truth is, that though human institutions appear to be, and indeed often are, the obvious and obtrusive causes of much mischief to society, they are, in reality, light and superficial, in comparison with those deeper-seated causes of evil, which result from the laws of nature and the passions of mankind (MALTHUS, 1826, Livro III, p. 20).

Godwin entende que "inveja, malícia, vingança”, “egoísmo”, “ansiedade”, "ganância”, todos estes vícios são originados pela instituição da propriedade privada, e que a filantropia generalizada acabaria com a existência de todos. Se, contudo, uma sociedade completamente benevolente fosse estabelecida com igualdade plena nas condições descritas por Godwin, argumenta, Malthus, o princípio da população levaria a um crescimento demográfico que faria com que a busca pela subsistência, "a poderosa lei da auto-preservação" (MALTHUS, 1826, Livro III, p. 27), revertesse o homem a seu estado natural com todos os vícios e ao "império do autointeresse". 


\subsubsection{Nature vs. Nurture}

O embate "nature vs. nurture", já inserido na crítica aos utópicos, encontra-se de maneira peculiar na obra de Malthus. Uma tese central subjacente a todo o Essay é justamente a necessidade de se levar em conta a importância da natureza humana, isto é, de comportamentos e paixões amplamente compartilhados por todos os homens independente da cultura que estão inseridos. Isto não quer dizer, entretanto, que Malthus rejeite a importância de instituições como influências significativas sobre a ação do homem e suas consequências a posição malthusiana é uma de relativo equilíbrio: ambos importam - ainda que maior atenção seja dada à "nature" e não a "nurture" na obra.

A concepção geral de Malthus é que a natureza humana trata-se uma série de fortes prédisposições, não necessariamente inevitáveis em um nível individual. Isto é, é possível que um indivíduo, por meio de seu autocontrole e suas capacidades mentais supere as pressões que sua natureza o impõe, mas é impossível que ele não sofra esta pressão. Para ilustrar este argumento, vale a pena recuperar o seguinte trecho já citado anteriormente e seu complemento:

\footnotetext{
If we are intemperate in eating and drinking, our health is disordered; if we indulge the transports of anger, we seldom fail to commit acts of which we afterwards repent; if we multiply too fast, we die miserably of poverty and contagious diseases. The laws of nature in all these cases are similar and uniform. [...] The uneasiness we feel from repletion, the injuries that we inflict on ourselves or others in anger, and the inconveniencies we suffer on the approach of poverty, are all admonitions to us to regulate these impulses better (MALTHUS, 1826, Livro IV, p. 256-257).
}

Estes exemplos podem ser complementados por o que Malthus denomina de uma “indolência natural” do homem (LEVIN, 1966, p. 94), isto é, a tendência em não exercer esforço sem que haja necessidade, já mencionado anteriormente. É apenas na presença de incentivos que o homem é capaz de superar esta indolência. A incapacidade de superar esta "preguiça" natural resulta em um bem-estar reduzido, enquanto o sucesso em sua superação resultaria em maior riqueza e bem-estar. Assim, é possível regular os impulsos da natureza humana, e, de acordo com o sua utilitarismo teológico, aceitar que a dor ou a felicidade que nos traz cada ação seja um sinal do que devemos fazer. De modo algum, portanto, Malthus adota uma visão de determinismo natural. O livre arbítrio de cada individuo ainda é soberano, ainda que direcionado por instituições e sob a influência constante da natureza humana.

É muito mais fácil, contudo, que um indivíduo específico, em casos particulares, seja capaz de superar as pressões de suas paixões naturais, do que a sociedade como um todo realize 
este feito. É ingênuo esperar esta possibilidade em nível agregado - segundo Malthus, é impossível, na ausência de instituições reguladoras, que sociedade em geral não ceda às paixões naturais se as tentações se manifestarem de maneira ampla, justamente devido a onipresença das leis naturais: “( ...) as tentações, de acordo com todos os princípios conhecidos da natureza humana, irão prevalecer" (MALTHUS, 1826, Livro III, p. 117).

É neste ponto que o papel das instituições se manifesta em conjunção com a natureza humana na obra de Malthus - para o autor, instituições inadequadas são aquelas que intensificam tentações naturais tamanhas sobre o homem que tende a levá-lo ao vício (em nível individual), e certamente leva a sociedade como um todo ao vício em nível agregado. Instituições adequadas são aquelas que levam ao homem a agir de maneira virtuosa, certamente se manifestando em um aumento da utilidade geral, em níveis agregados ${ }^{35}$. Os esquemas utópicos de Godwin e Condorcet, por exemplo, assim como a Lei dos Pobres, se enquadram claramente em instituições que alimentam as tentações humanas mais viciosas - que levam à preguiça, à luxúria irrestrita, à indulgência, e, em última instância ao instinto de sobrevivência se manifestando de modo violento quando a ilusão de conforto econômico é dissipada:

The spirit of benevolence, cherished and invigorated by plenty, is repressed by the chilling breath of want. The hateful passions that had vanished re-appear. The mighty law of self-preservation expels all the softer and more exalted emotions of the soul. The temptations to evil are too strong for human nature to resist (MALTHUS, 1826, Livro III, p. 27).

Um exemplo de instituição adequada, para Malthus, seria a instituição do casamento ${ }^{36}$. Utilizando o conceito de casamento de modo relativamente amplo, Malthus se refere em particular a presença de uma cultura entre os homens que os levam a desejar sustentar uma família, recebendo em troca as alegrias deste modo de vida:

It would be by no means necessary or proper in these explanations to underrate, in the smallest degree, the desirableness of marriage. It should always be represented as, what it really is, a state peculiarly suited to the nature of man, and calculated greatly to advance his happiness and remove the temptations to vice. [...] And a strong conviction in a young man of the great desirableness of marriage, with a conviction at the same time that the power of supporting a family was the only condition which would enable him really to enjoy its blessings, would be the most effectual motive imaginable to industry and sobriety before marriage, and would powerfully urge him to save that

\footnotetext{
${ }^{35}$ Basicamente, as instituições são vistas como sistemas de incentivo em um ambiente dominado pela natureza humana (que é imutável e onipresente).

${ }^{36} \mathrm{O}$ casamento, para Malthus, é uma instuição devido justamente aos hábitos e obrigações que este arranjo implica - esta instituição estaria de acordo com o impulso natural da paixão entre os sexos e de prover pela família. Entretanto, em condições específicas (como dificuldades econômicas, ou outras circunstâncias inesperadas), a ausência desta instituição poderia fazer com que este impulsos naturais não fossem fortes o suficiente para manter a conexão familiar, fundamental para Malthus. Um vínculo cultural (e preferencialmente formal), como o casamento, serviria para reforçar institucionalmente a família.
} 
superfluity of income which single labourers necessarily possess, for the accomplishment of a rational and desirable object, instead of dissipating it, as is now usually done, in idleness and vice. (MALTHUS, 1826, Livro IV, p. 353)

Note que este exemplo de Malthus indica a capacidade de instituições, de enfatizar as virtudes e reprimir vícios ainda que as tentações da natureza humana estejam presentes. Isto é, a tentação de dissipar riqueza com gastos supérfluos, por exemplo, existe de modo pronunciado para indivíduos com baixa preferência temporal ${ }^{37}$, mas uma cultura que enfatiza a importância de sustentar uma família sob a instituição sagrada do casamento é capaz de superar esta tentação e redirecionar os esforços do homem à uma certa "caridade" virtuosa em favor de seus entes mais próximos.

Uma vez que as tendências humanas naturais são imutáveis e onipresentes (ainda que superáveis), é de se esperar que Malthus não tenha nenhuma pretensão em alterá-las, e use grande parte de sua obra apenas para descreve-las. Já as instituições, são flexíveis, e, portanto, merecem ampla discussão realizada no Essay. Isto é, frequentemente, Malthus está criticando algum esquema utópico que tem a pretensão verdadeira de alterar fundamentalmente algum pilar da natureza humana, nestes casos, a resposta é a simples descrição da natureza humana e a afirmação de sua imutabilidade (MALTHUS, 1826, Livro III e IV, p. 27, p. 34, p. 117, p. 340, p. 344, p. 370). Por exemplo, ao criticar a proposta de que o Estado seja encarregado de cuidar de filhos abandonados, Malthus simplesmente invoca a incapacidade da socidedade substituir a paixão natural da afeição parental:

With regard to illegitimate children, after the proper notice had been given, they should
not be allowed to have any claim to parish assistance, but be left entirely to the support
of private charity. [...]Its principal value is on account of its being the object of one of
the most delightful passions in human nature---parental affection. But if this value be
disregarded by those who are alone in a capacity to feel it, the society cannot be called
upon to put itself in their place. [...] At present the child is taken under the protection
of the parish, and generally dies, at least in London, within the first year. [...] By the
laws of nature, a child is confided directly and exclusively to the protection of its parents
(MALTHUS, 1826, Livro IV, p. 340-341).

Neste ponto, além da crítica inicial ser quanto à uma tentativa fracassada de alterar a condição natural da intransferibilidade da responsabilidade parental, há também uma crítica institucional: se as condições econômicas de sobrevivência dos pais (ou de um dos pais) de uma criança forem tais que a tentação de abandonar a criança existe, oferecer uma instituição que

\footnotetext{
${ }^{37}$ Tendência inversamente relacionada com o nível de educação do indivíduo (SILBER, 1986, p. 16), como será discutido na seção 5.4 .
} 
garante, ao menos oficialmente, cuidados às crianças abandonadas, é um incentivo enorme ao abandono. De fato, esta é uma observação do que ocorria na sociedade inglesa da época:

But our laws, in opposition to the laws of nature, say, that if the parents forsake their child, other persons will undertake to support it; or, if the man forsake the woman, that she shall still meet with protection elsewhere (MALTHUS, 1826, Livro IV, p. 342).

Seria necessário, portanto, que instituições no sentido oposto fossem adotadas - de punição ao abandono, para contrabalancear quaisquer tentações originadas do instinto à sobrevivência pessoal que possivemente esteja influenciando tal decisão: "If the parents desert their child, they ought to be made answerable for the crime" (MALTHUS, 1826, Livro IV, p. $340)$.

O caso do abandono de crianças é útil para discutir outra faceta do comportamento humano guiado pela natureza ou instituições: frequentemente paixões naturais são opostas e se contrabalanceiam. No caso discutido, o instinto pela sobrevivência pessoal está em direto confronto com a afeição paternal (que é uma manifestação indireta do instinto reprodutivo). Qual destas duas paixões deve se sobressair dependerá, certamente, das condições econômicas da família em questão, bem como da mentalidade ou cultura dos indivíduos envolvidos e das instituições presentes que podem incentivar uma decisão em detrimento de outra. Por exemplo, Malthus explica que é comum na Inglaterra o abandono de crianças e esposa por parte do pai segundo ele, este comportamento estaria sendo instigado por uma instituição inadequada, que força homens a se casarem com mulheres com as quais eles têm filhos fora do casamento, sob ameaça de prisão ${ }^{38}$. Este tipo de relacionamento forçado tornaria os homens ainda mais propensos ao abandono de suas responsabilidades, especialmente em conjunto com outras instituições que garantiriam o sustento da mulher e filhos abandonados (MALTHUS, 1826, Livro IV, p. 344-345). A provisão da Lei dos Pobres, portanto, que garantia o sustento de crianças abandonadas deveria ser abolida - o argumento de Malthus é que, assim como quaisquer filhos necessariamente sofrem com os vícios de seus pais (e se beneficiam de suas virtudes), os filhos abandonados deveriam sofrer igualmente com esta ação, que não é um caso especial:

In the moral government of the world, it seems evidently necessary, that the sins of the fathers should be visited upon the children; and if in our overweening vanity we imagine, that we can govern a private society better by endeavouring systematically to counteract this law, I am inclined to believe, that we shall find ourselves very greatly mistaken. (MALTHUS, 1826, Livro IV, p. 345).

\footnotetext{
${ }^{38}$ Malthus defende alguma punição ao homem que manipulou uma mulher a se relacionar com ele fora do casamento, mas afirma que força-lo a casar como punição, especificamente, é inadequado.
} 
Como mencionado, este é um caso em que dois instintos naturais estão em oposição e instituições podem “desempatar" o embate, preferencialmente em favor de um comportamento virtuoso.

\subsubsection{Lei dos Pobres sob a lente da natureza humana}

A base da oposição de Malthus à Lei dos Pobres depende de um arcabouço teórico que prevê flutuações econômicas baseadas nas consequências demográficas do Princípio da População (que decorre da natureza humana). Na primeira edição do Essay, Malthus descreve estas oscilações como caracterizadas por períodos em que a população está em condições de se sustentar com a quantidade de alimentos disponíveis, levando a um conforto que gera um aumento populacional inevitável. Nestas condições, a situação se inverte rapidamente, pois:

The food therefore which before supported seven millions must now be divided among
seven millions and a half or eight millions. The poor consequently must live much
worse, and many of them be reduced to severe distress. The number of labourers also
being above the proportion of the work in the market, the price of labour must tend
toward a decrease, while the price of provisions would at the same time tend to rise.
(...) During this season of distress, the discouragements to marriage, and the difficulty
of rearing a family are so great that population is at a stand (MALTHUS, 1998 [1798],
p. 9)

Quando a população para de crescer, os salários voltam a subir, levando o padrão de vida dos trabalhadores a retornar ao nível de maior conforto anterior, reiniciando o movimento oscilatório:

The situation of the labourer being then again tolerably comfortable, the restraints to population are in some degree loosened, and the same retrograde and progressive movements with respect to happiness are repeated (MALTHUS, 1998 [1798], p. 9).

Apesar de Malthus não estar se referindo especificamente de alívio à pobreza, o argumento mais amplo dele já permite prever sua posição: um ganho de renda do pobre necessariamente reduz os controles positivos e preventivos, desimpedindo a poderosa força de crescimento populacional e diluindo qualquer ganho na produção de alimentos para o nível de subsistência - agora, de um número ainda maior de pessoas. No capítulo 5 da primeira edição do Essay, a prevista posição de rejeição da Lei dos Pobres se manifesta: 
To remedy the frequent distresses of the common people, the poor laws of England have been instituted; but it is to be feared, that though they may have alleviated a little the intensity of individual misfortune, they have spread the general evil over a much larger surface. It is a subject often started in conversation and mentioned always as a matter of great surprise that, notwithstanding the immense sum that is annually collected for the poor in England, there is still so much distress among them (MALTHUS, 1998 [1798], p. 24) $)^{39}$.

Tratando o tema sob a perspectiva de que Lei dos Pobres é uma instituição que interage com a natureza humana gerando estes processos demográficos oscilatórios, a questão a ser respondida é: esta instituição gera manifestações virtuosas ou viciosas em sociedade? E, portanto, geram possui consequências positivas ou negativas em geral? No caso das Leis dos Pobres, o julgamento de Malthus é bastante direto - por razões práticas que envolvem sua própria teoria econômica e por não levar em conta a natureza humana, o auxílio para enfrentar a pobreza na Inglaterra não poderia, de modo algum, ser considerado adequado - ainda que algumas pessoas se beneficiaram do esquema, a tendência é de redução da utilidade geral:

I feel persuaded that if the poor-laws had never existed in this country, though there might have been a few more instances of very severe distress, the aggregate mass of happiness among the common people would have been much greater than it is at present (MALTHUS, 1826, Livro III, p. 86).

Malthus apresenta uma série de objeções diretas à Lei dos Pobres, a primeira sendo um argumento puramente econômico, que se resume a uma noção similar à neutralidade da moeda: o aumento na renda nominal das pessoas pobres causaria apenas o aumento dos preços nos alimentos, mas não alteraria sua escassez ${ }^{40}$ (MALTHUS, 1826, Livro III, p. 64-65). Winch (1989, p. 43-45) refina o conceito como uma premissa de "extrema inelasticidade da oferta de alimentos", fazendo com que um aumento de demanda resultasse apenas em preços mais altos, sem mudanças na quantidade produzida. O segundo argumento é o próprio princípio da população, ou seja, mesmo quando por um aumento da demanda de alimentos há alguma mudança produtiva (saindo do caso da neutralidade da moeda), a população se eleva pois os

\footnotetext{
${ }^{39}$ Vale ressaltar que é notável como todos eles seriam passíveis de transposição até mesmo para o caso da caridade privada voluntária na primeira edição do Essay.

${ }^{40}$ Malthus, contudo, qualifica esta neutralidade da moeda. Ele reconhece que haveria sim a possibilidade de que uma nova realocação de recursos poderia causar maior produção de alimentos ao estimular aquele mercado específico, mas que ainda assim, os efeitos seriam anulados pelo próprio crescimento populacional consequente deste pequeno aumento na quantidade de alimentos disponíveis, causando uma divisão de qualquer ganho em um número ainda maior de pessoas:

"It will be said, perhaps, that the increased number of purchasers in every article would give a spur to productive industry and that the whole produce of the island would be increased. This might in some degree be the case. But the spur that these fancied riches would give to population would more than counterbalance it, and the increased produce would be to be divided among a more than proportionally increased number of people" (MALTHUS, 1998 [1798], p. 25).
} 
controles positivos e preventivos são relaxados pela situação de maior abundância, fazendo com que não muito tarde a situação de escassez anterior se estabeleça novamente. O seguinte trecho resume o raciocínio:

Independently of any considerations respecting a year of deficient crops, it is evident, that an increase of population, without a proportional increase of food, must lower the value of each man's earnings. The food must necessarily be distributed in smaller quantities, and consequently a day's labour will purchase a smaller quantity of provisions. An increase in the price of provisions will arise either from an increase of population faster than the means of subsistence, or from a different distribution of the money of the society (MALTHUS, 1826, Livro III, p. 81).

Como se pode observar, já se conecta ao argumento de elevação de preços a grande objeção de Malthus à Lei dos Pobres, que se dava com base no seu Princípio da População. Era certo, na visão de Malthus, que sob a Lei dos Pobres, quaisquer ganhos que as classes mais baixas pudessem hipoteticamente realizar em termos reais, a despeito da baixa elasticidade dos alimentos, seria erodido pelo crescimento populacional diretamente ocasionado pelo impulso natural de se reproduzir. Simultaneamente, a falta de vínculação entre subsistência e esforço certamente desincentivaria o trabalho, reduzindo ainda mais o produto a ser distribuído entre os pobres. $\mathrm{O}$ argumento é essencialmente calcado nas leis naturais discutidas na obra - ao notar a completa ignorância das antigas Leis dos Pobres à ordem natural, Malthus faz a seguinte comparação:

Canute, when he commanded the waves not to wet his princely foot, did not in reality assume a greater power over the laws of' nature (MALTHUS, 1826, Livro III, p. 87).

A inelasticidade na oferta de alimentos e o Princípio da População não eram as únicas objeções de Malthus ao auxílio público aos pobres. Repetindo o argumento já apresentado por Smith na Riqueza das Nações, Malthus também se coloca em oposição às regulações que impedem a mobilidade do trabalho, as "settlement laws", parte fundamental das Leis dos Pobres (MALTHUS, 1826, Livro III, p. 85).

Do ponto de vista moral, dois aspectos podem ser considerados: primeiramente, a obrigação moral de Malthus com o já mencionado "teste da utilidade"41 (MALTHUS, 1826, Livro IV, p. 361). Isto é, as consequências últimas das Leis dos Pobres são negativas e, portanto, isto já é suficiente para condená-las. Adicionalmente, o debate quanto a Lei dos Pobres na Inglaterra não se limitava a uma lente especificamente utilitarista - os argumentos morais que moldariam as reformas futuras da legislação levariam em conta questões como responsabilidade individual versus social. Como já mencionado, para Malthus, embora a condição inicial do

\footnotetext{
${ }^{41}$ Ainda que em sua forma peculiar aqui denominada de "utilitarismo teológico".
} 
pobre seja essencialmente arbitrária e sua falta de instrução consequência desta arbitrariedade (o pobre não é culpado, por esta condição), a responsabilidade pela continuidade de sua miséria só poderia ser considerada própria, uma vez que decorre das ações individuais imprudentes:

Poverty was made an individual responsibility and divinely justified, while any attempt at relief could be shown to be contrary to natural law, and thus doomed to failure (FISHLOW, 1958, p. 46).

Não só seria responsabilidade do pobre a perpetuação de sua condição, mas também este sofrimento era necessário para que alguma possibilidade de superação individual se tornasse possível. A Lei dos Pobres, portanto, removia artificialmente este sentimento de responsabilidade e precisaria ser abolida.

\subsubsection{Condições institucionais para o desenvolvimento do freio moral}

Mesmo reduzidas as distorções sociais criadas pelas Leis dos Pobres, persistem fortes obstáculos para a "felicidade humana" e "mitigação dos males" 42 que o princípio da população ocasiona. A redução da miséria, desacompanhada de vícios que controlam a natalidade, seria uma raridade social - tentações e paixões humanas conspiravam contra a noção de que tal mundo pudesse ser alcançado facilmente. Contudo, esta visão pessimista (que permeia a primeira edição do Essay), foi substituída já na segunda edição do Essay pela esperança de que a virtude do "freio moral" poderia ser desenvolvida.

Ao introduzir o "freio moral", Malthus estaria propondo uma solução para os problemas descritos na primeira edição do Essay (WINCH, 1987, p. 36). Ao mesmo tempo em que isto adiciona algumas nuances a seus ataques à Lei dos Pobres - propondo, por exemplo, a abolição muito gradual do esquema, de modo que não afetasse nenhum indivíduo vivo que já depende do auxílio público (WINCH, 1987, p. 48) -, haveria, agora, uma possibilidade em que o auxílio possa ser bem direcionado para incentivar e recompensar o indivíduos com maior freio moral, a caridade privada.

O desenvolvimento do freio moral dependeria, certamente, de instituições adequadas. Uma das razões para a mudança de atitude de Malthus (que na primeira edição do Essay rejeitava a possibilidade de que a paixão entre os sexos poderia ser controlada), se deu

\footnotetext{
${ }^{42}$ Estas expressões são usadas no subtítulo da sexta edição do Ensaio.
} 
principalmente pelas suas observações empíricas. Mais especificamente, Malthus teria se tornado ciente do desenvolvimento deste controle preventivo virtuoso, em ampla escala, em países escandinavos (JENSEN, 1999, p. 450). Na viagem realizada pela Dinamarca, Noruega e Suécia em 1799, Malthus observou, por exemplo, que simples regras como a legislação dinamarquesa que impedia a convocação militar obrigatória de homens acima dos 28 anos tinha um efeito demográfico significante: em consequência desta instituição, teria se tornado um costume racional evitar ao máximo possível a paternidade antes desta idade - reduzindo a possibilidade de deixar a esposa e os filhos para servir à pátria.

O papel institucional no desenvolvimento do freio moral, representa, ao menos uma parcial concessão ao argumento de Godwin, apesar da manutenção das críticas já apresentadas. Malthus estaria aceitando um grau de flexibilidade sobre a natureza humana, o que é ainda muito distante da flexibilidade radical defendida por Godwin e Condorcet, mas já representa algum nível de acordo - Malthus admite, portanto, a possibilidade de controle dos desejos carnais através de uma educação moral extensa à sociedade toda, mas não a redução ou abolição destes desejos, como Godwin proporia (GODWIN apud JENSEN, 1999, p. 452), sempre presentes por natureza.

Quais seriam os pré-requisitos institucionais para o desenvolvimento do freio moral? Em geral, seria necessário que as classes médias e baixas da sociedade pudessem ter uma perspectiva positiva do futuro, que sua situação seja respeitável, para que exista alguma vontade de exercer prudência ${ }^{43}$. Assim, o que pode ser denominado de "causas morais" seriam fundamentais (MALTHUS apud SILBER, 1986 [1827], p. 15). E estas, por sua vez, dependiam muito do arranjo institucional da sociedade:

[The moral causes depend] Very much on the government, on the strict and equal administration of justice, on the perfect security of property, on civil, religious and political liberty; for people respect themselves more under favourable circumstances of this kind and are less inclined to marry, without the prospect of more physical sustenance for their children (MATHUS apud SILBER, 1986 [1827], p. 15).

A ausência destas liberdades institucionais, por sua vez, produziria um ambiente de incerteza radical quanto ao futuro (SILBER, 1986, p. 15). A presença de limites à arbitrariedade de autoridades, gera uma capacidade de planejamento e busca por prosperidade, o que incluiria o desenvolvimento do freio moral.

\footnotetext{
${ }^{43}$ Como expressou Malthus em um comitê sobre emigração: “o hábito de olhar para o futuro" (MALTHUS apud SILBER, 1986 [1827], p. 15).
} 
Este reconhecimento do papel de instituições como regulador importante dos impulsos naturais também aparece no Essay, em que Malthus destaca não apenas as liberdades civis como pré-requisitos para o desenvolvimento do freio moral, mas também a educação das classes menos privilegiadas (WINCH, 1987, p. 47). No seguinte trecho este desenvolvimento institucional, alinha-se com a visão de Smith quanto à importância da educação para o desenvolvimento da prudência na sociedade:

The fairest chance of accomplishing this end [securing the operation of the prudential check to marriage to a sufficient degree] would probably be by the establishment of a system of parochial education upon a plan similar to that proposed by Adam Smith (MALTHUS, 1826, Livro IV, p. 352).

Os efeitos da difusão de um nível mínimo de educação seriam múltiplos ${ }^{44}$, contudo o mais relevante para o desenvolvimento do freio moral seria a redução da preferência temporal de indivíduos educados (SILBER, 1986, p. 16). Isto é, a educação possibilita que uma perspectiva de que um futuro mais próspero seja almejado, e, portanto, ajuda no desenvolvimento de comportamentos prudentes como o freio moral, a despeito dos impulsos que a natureza humana possa impor na direção oposta.

Desse modo, instituições que reduzem a incerteza quanto ao futuro, e que auxiliam na difusão do conhecimento através da educação, seriam instituições adequadas para o desenvolvimento do freio moral, que por sua vez, é condição necessária para o progresso social.

Esta visão exposta por Malthus reflete, em parte, as discussões através de cartas trocadas com Nassau Senior - que criticava a inflexibilidade que Malthus dava às leis naturais frente às instituições, especialmente nas primeiras edições do Essay. Em uma carta para Malthus, por exemplo, Senior escreve sobre a tendência à superpopulação:

What I deny is that, under wise institutions, there is any tendency to this state of things. I believe the tendency to be the reverse (SENIOR apud FORSBERG, 2006 [1829], p. 42).

E converge com o Essay, parcialmente, em termos de quais seriam estas instituiçõos:

[...] knowledge, security of property, freedom of external and internal exchange, and equal admissibility to rank and power, are the principal causes which at the same time promote the increase of subsistence, and by elevating the character of the people lead them to keep at a slower rate the increase of number (SENIOR apud FORSBERG, 2006 [1829], p. 43) ${ }^{45}$.

\footnotetext{
${ }^{44} \mathrm{Um}$ aumento no valor do tempo (pois a busca por conhecimento se torna um prazer a mais que o consome), uma redução na preferência temporal das pessoas educadas (aumento da prudência) e externalidades positivas (SILBER, 1986, p.16).

${ }^{45}$ Malthus não dá indício de que uma "admissibilidade igual à posição e poder" na sociedade seria uma destas instituições - apenas a liberdade, conhecimento e propriedade são destacadas por Malthus.
} 
Contudo, enquanto a sexta edição do Essay certamente reflete o sentimento de que as instituições podem sim ser instrumentais no estabelecimento de um freio moral, uma posição que Malthus manteve completamente inalterada que diverge das críticas de Senior é a presença da tendência natural à superpopulação. Esta "tendência", interpretada por Malthus, não é um destino se atos virtuosos prevalecerem ${ }^{46}$.

\subsection{Caridade: discriminada e indiscriminada}

Benevolência é um comportamento bastante geral para descrever diferentes tipos de condutas e costumes caridosos mais específicos. Em geral, quando se fala de caridade, imaginase o auxílio voluntário ${ }^{47}$ às pessoas necessitadas e desconhecidas (ou relativamente distantes). Contudo, na visão de Malthus, os benefícios que os pais oferecem ao cuidar de seus filhos, ou ainda o auxílio de um familiar ou amigo próximo, podem ser considerados caridade. Seria a forma mais natural de caridade. Já a caridade direcionada às pessoas mais distantes, segundo Malthus, tem uma função natural de aproximá-las, de manter uma sensação semelhante a de uma família estendida ao resto da humanidade:

The apparent end of the impulse of benevolence is, to draw the whole human race together, but more particularly that part of it which is of our own nation and kindred, in the bonds of brotherly love; and by giving men an interest in the happiness and misery of their fellow-creatures, to prompt them, as they have power, to mitigate the partial evils arising from general laws, and thus to increase the sum of human happiness (MALTHUS, 1826, Livro IV, p. 362).

Não há dúvidas de que a benevolência, era vista sob uma luz bastante positiva por Malthus, sendo um exercício virtuoso se executada corretamente. Se por um lado a conduta humana é fortemente permeiada pelo autointeresse, que "em excesso amor próprio se tornaria o vício odioso do egoísmo" (SIMONS, 1955, p. 61), por outro lado a "Providência [natureza] teria implantado no coração humano o desejo de ajudar os outros, benevolência" (SIMONS, 1955, p. 61). A necessidade de equilíbrio prudencial entre autointeresse e benevolência,

\footnotetext{
46 As objeções de Senior à Malthus se pautam principalmente na observação empírica de que o Princípio da População não teria se realizado de fato, empiricamente (SOLOW, 1962, p. 272), caso contrário todas as sociedades estariam em condições identicamente miseráveis (VINT, 2013). Esta interpretação de tendência não é adequada ao pensamento malthusiano, ainda que as críticas possam ter flexibilizado a posição de Malthus.

${ }^{47} \mathrm{O}$ caráter voluntário, aliás, é considerado essencial na definição de caridade para Malthus (MALTHUS, 1826, Livro IV, p. 365).
} 
portanto, constituí virtude sob a lenta malthusiana - excessos, para qualquer um dos lados, vício ${ }^{48}$.

There were those who thought benevolence could or should be man's dominant motivation; with this Malthus could not agree. He believed that to live primarily according to the principle of benevolence would require man to possess perfect foresight of the effects of his actions, for mistaken benevolence may be very harmful. It is a blessing therefore, that in man's nature self-love is much the stronger; for even the simplest person may understand and follow it and thus tend to promote the common good (SIMONS, 1955, p. 61).

Como se pode observar, a visão malthusiana de natureza humana quanto a autointeresse e benevolência é complexa. O leitor conseguiria encontrar trechos em que Malthus afirma que um ou outro desses comportamentos é natural ao homem e, isoladamente, interpretar erroneamente que Malthus entendia o homem como unicamente auto-interessado, ou essencialmente benevolente, quando em realidade, ambos os impulsos coexistem naturalmente. Sob a lente malthusiana, são desejos simultâneos, o de melhorar a própria condição e o de melhorar a condição alheia.

Frequentemente, o homem é demasiado auto-interessado, mas o que seria ainda mais preocupante para Malthus é a possibilidade ocasional de um excesso de benevolência. Assim como o impulso relacionado à paixão entre os sexos, o impulso à benevolência deve ser regulado - sob certas circunstâncias ele se manifesta como uma virtude, e sob outras, como um vício.

O que Malthus denomina de "caridade indiscriminada" é o impulso a benevolência descuidado, que tende a alimentar as tentações humanas naturais, levando a um comportamento prejudicial ao próprio receptor do benefício. A regulação deste impulso à benevolência, portanto, seria essencial:

An important and interesting inquiry yet remains, relating to the mode of directing our
private charity, so as not to interfere with the great object in view, of meliorating the
condition of the labouring classes of people, by preventing the population from pressing
too hard against the limits of the means of subsistence. The emotion which prompts us
to relieve our fellow-creatures in distress is, like all our other natural passions, general,
and, in some degree, indiscriminate and blind. Our feelings of compassion may be
worked up to a higher pitch by a well-wrought scene in a play, or a fictitious tale in a
novel, than by almost any events in real life: and if among ten petitioners we were to
listen only to the first impulses of our feelings without making further inquiries, we
should undoubtedly give our assistance to the best actor of the party. It is evident,
therefore, that the impulse of benevolence, like the impulses of love, of anger, of
ambition, the desire of eating and drinking, or any other of our natural propensities,

${ }^{48}$ Esta caracterização revela uma teoria de vícios e virtudes de Malthus mais próxima de uma visão aristotélica (qualquer virtude em excesso se torna um vício), ainda que a métrica última seja a utilidade. Note que esta noção de vícios e virtudes difere da visão de Smith, em que situações específicas demandam reações específicas, podendo ser um comportamento próprio ou impróprio à situação em questão. 
must be regulated by experience, and frequently brought to the test of utility, or it will defeat its intended purpose (MALTHUS, 1826, Livro IV, p. 361).

Percebe-se que o argumento de Malthus vai em um sentido praticamente oposto à noção de autocomando de Smith, isto é, Malthus se preocupa que não tenhamos autocomando suficiente para limitar nossa benevolência, enquanto Smith se preocupa que nosso autocomando seja insuficiente para que sejamos benevolentes o bastante através da simpatia. Na TMS o conceito de autocomando aparece em ocasião para ilustrar como controlar as paixões é necessário para realizar a virtude de sacrificar o seu próprio interesse em prol do outro, já em Malthus a contenção da própria "simpatia", no vocábulo Smithiano, é necessária para que atos de generosidade irracionais sejam evitados. A benevolência seria um "impulso" a ser guiado cuidadosamente (e não um esforço de nossa humanidade, como colocaria Smith). Como o trecho acima explica, existe uma tendência humana em seguir este impulso de aliviar o sofrimento alheio de acordo com a aparência da angústia do outro. Assim, há o risco evidente de recompensar apenas aqueles que fingem ou apresentam suas aflições de modo mais convincente, e não aqueles que realmente merecem (que possuem um "freio moral", por exemplo), mas que estão igualmente com “dificuldades inevitáveis".

De modo similar, outro contraste entre Smith e Maltbhus é o autocontrole por parte do receptor do auxílio. Enquanto Smith afirmaria que o indivíduo que sofre requer algum autocomando também, (pois ao tentar obter a simpatia alheia precisaria reduzir a aparência de seu sofrimento apresentado ${ }^{49}$ ), para Malthus, a amplificação da aparência de sofrimento seria efetiva, e não sua camuflagem.

A caridade indiscriminada, justamente por ser uma forma de auxílio em que os impulsos benevolentes do doador não estão sob controle (assim como esquemas distributivos por parte do governo, tal como a Lei dos Pobres), não leva em conta o caráter da pessoa que recebe o auxílio, nem traz condições de mudança deste caráter, e consequentemente, gera dependência e dissipação rápida de qualquer alívio gerado pelo ato benevolente:

But as experience has proved, I believe, without a single exception, that poverty and misery have always increased in proportion to the quantity of indiscriminate charity, are we not bound to infer, reasoning as we usually do from the laws of nature, that it is an intimation that such a mode of distribution is not the proper office of benevolence? (MALTHUS, 1826, Livro IV, p. 370).

\footnotetext{
${ }^{49} \mathrm{Na}$ TMS, Smith expressa sobre uma pessoa que sofre e requer simpatia, auxílio:

" (...) he can only hope to obtain this by lowering his passion to a pitch, in which the spectators are capable of going along with him. He must flatten, if I may be allowed to say so, the sharpness of its natural tone, in order to reduce it to harmony and concord with the emotions of those who are about him" (SMITH, 1984 [1759], p.22).
} 
Esta forma de pensar se conecta diretamente com a utilitarismo teológico de Malthus. Isto é, ao mesmo tempo que uma ação qualquer, como a caridade privada, deve ser considerada sob o "teste da utilidade" (MALTHUS, 1826, Livro IV, p. 361), há de se considerar, neste teste, as consequências das leis naturais ditadas por Deus, que através da felicidade ou miséria geradas, nos guiariam à ação adequada. Uma destas leis, como Malthus menciona é uma referência direta a São Paulo: "Se um homem não trabalhar, ele também não irá comer" (MALTHUS, 1826, Livro IV, p. 370) - ou seja, a indisposição ao trabalho deve desqualificar um indivíduo ao recebimento da caridade privada, pois sua miséria no longo prazo seria certamente perpetuada.

O modo adequado de se realizar a caridade, para Malthus necessita de algumas características. A caridade precisa: (i) ser voluntária; (ii) ser discriminatória; (iii) ser condicionada ao aperfeiçoamento do caráter do indivíduo; (iv) ser completamente discricionária quanto a continuidade do benefício.

A redundância que Malthus adota ao usar o termo "caridade voluntária" é intencional para se contrapor ao uso de alguns autores da expressão "caridade pública". Segundo Malthus, o caráter voluntário é essencial para o funcionamento das outras três características que tornam a caridade adequada. $\mathrm{O}$ aspecto voluntário é necessário para que o doador tenha o incentivo e capacidade de discriminar adequadamente entre um indivíduo merecedor e não merecedor de auxílio $^{50}$. As condições de aperfeiçoamento do caráter e a continuidade da caridade também são avaliadas com maior cuidado nas mãos da caridade privada. Como indica Malthus:

But it is far otherwise [compared to public charity] with that voluntary and active charity, which makes itself acquainted with the objects which it relieves; which seems to feel, and to be proud of the bond that unites the rich with the poor; which enters into their houses, informs itself not only of their wants, but of their habits and dispositions; checks the hopes of clamorous and obtrusive poverty, with no other recommendation but rags ; and encourages, with adequate relief, the silent and retiring sufferer, labouring under unmerited difficulties. This mode of exercising our charity presents a very different picture from that of any other (MALTHUS, 1826, Livro IV, p. 366).

E é este caráter voluntário que permite a seleção adequada de merecedores da caridade:

This kind of despotic power, essential to voluntary charity, gives the greatest facility to the selection of worthy objects of relief, without being accompanied by any ill consequences (MALTHUS, 1826, Livro IV, p. 369) ${ }^{51}$.

\footnotetext{
${ }^{50}$ Ou seja, separar os indivíduos prudentes, com freio moral, dos imprudentes, incapazes de controlar seus impulsos.

${ }^{51}$ Há um ceticismo por parte de Malthus quanto à capacidade e disposição do governo de realizar esta seleção que pode ser adequadamente feita pela caridade privada.
} 
Além disso, o caráter voluntário tem outro aspecto essencial, de não beneficiar apenas o receptor do benefício, mas também o doador (MALTHUS, 1827, Livro IV, p. 364), satisfazendo o impulso natural de ajudar o próximo. A “caridade pública” por sua vez, distancia o doador do receptor, impedindo quaisquer vantagens emocionais que o doador poderia aproveitar.

A caridade, portanto, para ter efeitos de bem-estar completos, precisaria ser voluntária. Isto é, privada, e mais que isso, deveria surgir de "motivos genuínos de benevolência", e não meramente de conveniência, tradição ou pressão social. Esta noção é um argumento mais que moral, uma vez que aponta a ineficiência intrínseca de esquemas involuntários de alívio aos pobres, anulado o ganho do doador. Ao mesmo tempo, por ser completamente ampla e tida como um "direito" dos mais pobres, a distribuição involuntária atrairia facilmente mentirosos e ingratos - bem como causaria uma sensação de injúria se por algum motivo suspensa. Já a caridade privada não: por ser discricionária e decorrente da benevolência e ação voluntária, dáse prioridade àqueles que se apresentam como merecedores do alívio, isto é, há um incentivo para conhecer a situação do necessitado e, portanto, melhor distribuir os recursos. Mais que isso, a caridade privada teria a grande vantagem de não criar relações de dependência, dada a incerteza de sua frequência, fazendo com que o recebedor se esforce para desenvolver "sua própria industriosidade e previdência” (MALTHUS, 1826, Livro IV, p. 408).

Estas vantagens da caridade privada são baseadas, portanto, não apenas no prazer que o doador voluntário receberia ao engajar no ato de generosidade, mas também, nos efeitos que o auxílio tem sobre o receptor. Em termos de utilidade, estes efeitos dependeriam da regulação da benevolência do doador, pois o homem prudente, com freio moral, tenderia a se beneficiar com a caridade, enquanto o imprudente alimentaria a sua própria corrupção moral com os recursos recebidos, não só prolongando seu sofrimento ao remover os incentivos para o desenvolvimento de freios morais, mas também potencialmente prejudicando sua família e sua sociedade:

If in the direction either of our public or our private charity we say that though a man will not work, yet he shall eat; and though he marry without being able to support a family, yet his family shall be supported; it is evident that we do not merely endeavour to mitigate the partial evils arising from general laws, but regularly and systematically to counteract the obviously beneficial effects of the general laws themselves (MALTHUS, 1826, Livro IV, p. 370)

Assim, para Malthus, não basta que a caridade seja privada. É necessário que o doador selecione cuidadosamente a quem direcionar seus recursos. Afinal, do que adiantaria doar 
excessivamente àqueles que pouco esforço fazem para evitar sua condição de miséria. As leis naturais ${ }^{52}$, segundo Malthus, estariam presentes para disciplinar o homem - são para os casos em que os melhores esforços do indivíduo falham, que a caridade deve ser primeiramente direcionada:

In the great course of human events, the best-founded expectations will sometimes be disappointed; and industry, prudence, and virtue not only fail of their just reward, but be involved in unmerited calamities. Those who are thus suffering in spite of the bestdirected endeavors to avoid it, and from causes which they could not be expected to foresee, are the genuine objects of charity. In relieving these, we exercise the appropriate office of benevolence, that of mitigating the partial evils arising from general laws; and in this direction of our charity therefore we need not apprehend any ill consequences. Such objects ought to be relieved, according to our means, liberally and adequately, even though the worthless were in much more severe distress (MALTHUS, 1826, Livro IV, p. 370-371).

Isto não significa, contudo, que em absolutamente todos os casos nós devemos julgar o caráter de uma pessoa antes de ajudá-la. Apesar desta ser uma regra geral, existem alguns casos específicos, em que não há risco de que a assistência promova incentivos perversos:

If a man break a leg or an arm, we are not to stop to inquire into his moral character before we lend him our assistance; but in this case we are perfectly consistent, and the touchstone of utility completely justifies our conduct. By affording the most indiscriminate assistance in this way, we are in little danger of encouraging people to break their arms and legs (MALTHUS, 1826, p. 372).

Em termos gerais, contudo, o caráter moral do recebedor deve ser levado em conta para uma distribuição adequada da benevolência.

Malthus não está necessariamente afirmando que ele não possui compaixão alguma para aqueles que não seriam selecionados pela caridade privada, mas sim que, seria ineficiente começar por indivíduos com tendências mais pronunciadas ao vício - de fato, há uma tendência a alimentar estes vícios através de uma instituição de caridade indiscriminada. O caráter discriminatório, deve ser acompanhado por uma tentativa de aperfeiçoar o caráter do indivíduo - e, para tal, seria fundamental que não se crie um relação de dependência contínua:

It is in the highest degree important to the general happiness of the poor, that no man should look to charity as a fund on which he may confidently depend. He should be taught that his own exertions, his own industry and foresight, are his only just ground of dependence; that if these fail, assistance in his distresses can only be the subject of rational hope; and that even the foundation of this hope will depend in a considerable degree on his own good conduct, and the consciousness that he has not involved himself in these difficulties by his indolence or imprudence. That in the distribution of our charity we are under a strong moral obligation to inculcate this lesson on the poor by a

\footnotetext{
${ }^{52}$ Como a citada por Malthus de St. Paul: "If a man will not work, neither shall he eat" (MALTHUS, 1998 [1798],
} p. 370) 
proper discrimination, is a truth of which I cannot feel a doubt (MALTHUS, 1826, p. 369).

Em conclusão, há espaço para caridade privada dentro da sociedade ideal malthusiana. Esta possibilidade, por sua vez, só se torna compatível com a teoria de Malthus graças a adição do conceito de freio moral, sem o qual, qualquer tentativa de eliminar a miséria levaria apenas a um crescimento populacional e difusão da pobreza. Com o freio moral, há a possibilidade selecionar pessoas que apresentem esta capacidade de atrasar casamentos e agir com prudência. O exercício destas virtudes, por sua vez, é dependente de instituições que garantem a liberdade, a propriedade e a educação das classes menos privilegiadas. Por esta razão, na visão malthusiana, apesar do Estado não possuir um papel direto na distribuição de auxílio aos pobres (como a Lei dos Pobres), há espaço para que o Estado garanta efetivamente que estas instituições estejam presentes e sólidas. Isto é, admite-se apenas um papel indireto do Estado na melhora da condição dos pobres.

Este posicionamento de Malthus é bastante diferente do de Bentham, o próximo autor a ser tratado nesta dissertação, que por sua vez, dava um espaço muito maior para o legislador interferir diretamente e moldar os motivos do comportamento humano, se necessário, com o uso da força. 


\section{BENTHAM E O VALE ENTRE A TEORIA E A PRÁTICA}

Por mais extensa e detalhada que tenha sido sua obra, Bentham não foi um intelectual que habitava a "torre de marfim", ou pelo menos, buscava constantemente escapar dela. Longe de viver confinado em seus pensamentos, a aplicação concreta de suas ideias no mundo foi uma missão assumida pelo próprio filósofo. Embora seus esforços públicos para manifestar-se como a encarnação viva de seu próprio sistema moral, foi neste salto, da teoria para a prática, que se deram suas maiores frustrações. No papel, seus sistemas eram, aparentemente, completos e complexos como sua experiência sugeria, mas no mundo, suas ideias foram apenas marginalmente aplicadas durante sua vida, embora intelectualmente aceitas ou consideradas por importantes pensadores ${ }^{53}$.

Uma das muitas ideias de Bentham que não se concretizaria foi a National Charity Company $^{54}$. O ambicioso projeto tinha como objetivo a solução dos problemas de administração do auxílio à indigentes ("pauper management") e substituiria a Lei dos Pobres na Inglaterra por uma instituição "racional", em que a eficiência e sucesso do empreendimento seria garantido pela consideração cuidadosa tanto das motivações humanas quanto pelo fim último de aumento da utilidade geral.

Para Bentham, o problema a ser resolvido pela NCC continha duas parte: o sofrimento dos indigentes, bem como a insegurança e incômodo da população com a pauperização do período. E apesar de as suas críticas à Lei dos Pobres terem sido bem recebidas (chegando a influenciar a reforma de 1834), e, embora suas ideias legislativas baseadas no princípio da utilidade tenham desfrutado de algum sucesso entre intelectuais de seu tempo, seus projetos eram grandiosos demais para acomodar todos os interesses políticos e econômicos envolvidos. $\mathrm{O}$ apetite de Bentham por reformas e empreendimentos cada vez mais radicais parecia seguir diretamente de suas teorias cada vez mais complexas, que buscavam sempre compreender integralmente princípios legislativos e de política pública, e, para isso, compreender integralmente a natureza humana e a filosofia moral mais adequada a ela.

No fim de sua vida Bentham apontaria a política como obstáculo fundamental às suas ideias. Revelava-se a força de uma contradição que ele mesmo entendia como superada dentro de sua teoria (DINWIDDY, 1989, p. 28): um sistema ético baseado na utilidade geral, ao lado de uma compreensão da natureza humana baseada na utilidade individual. Embora esse

\footnotetext{
${ }^{53}$ Em especial Dummont e James Mill (DINWIDDY, 1989, p. 18)

${ }^{54}$ Doravante "NCC".
} 
entendimento parecia se manifestar de modo benevolente na esfera do mercado (como autores liberais de seu tempo defendiam), na esfera da política, nem sempre haveria "interesse" da elite em implementar ideias direcionadas ao bem maior. Isto, a despeito dos esforços de Bentham para compatibilizar estas duas forças. Seja em seus códigos legislativos, que não seriam adotados por nenhuma nação, seja em seu Panopticon, um enorme projeto de prisão em formato circular, esquematizado para controle estrito do comportamento dos detentos, seja a NCC. Todos estes são exemplos de frustrações que a vida política impôs à Bentham, que tanto havia se dedicado a tais empreendimentos.

Esta parte do trabalho buscará explicar como este caminho que Bentham percorreu, da teoria para a prática, se expressa na questão da caridade, Lei dos Pobres e a NCC. Para isso, o ponto de partida é a própria compreensão de natureza humana articulada pelo autor, que influencia diretamente a oferta e demanda de auxílio econômico a indigentes e fundamenta muitos dos aspectos práticos necessários para o bom funcionamento de instituições destinadas a este fim. Em seguida, a base de toda sua teoria moral será analisada, partindo de seu "princípio da utilidade", bem como suas objeções a outros sistemas morais relevantes ao tema de caridade e auxílio. Estabelecidos estes dois pilares do pensamento benthamita, exploram-se suas críticas ao sistema de Lei dos Pobres do início do século XIX, e a detalhada solução proposta por ele na forma da NCC. As fontes primárias utilizadas são a sua mais famosa obra $A n$ Introduction ${ }^{55}$ to the Principles of Morals and Legislation (1789) e seus Tracts on the Poor Laws (1797)

O estilo de dissertação adotado por Bentham para descrever suas ideias é bastante sistemático. Havia uma preocupação em definir detalhadamente os termos utilizados, diferenciando-os uns dos outros, e tornando a leitura menos ambígua. Mais que isso, a sistematização era parte essencial do modo que Bentham desenvolvia seu raciocínio, e, portanto, precisa ser explicitada em certos pontos. A distinção entre "pobre" e “indigente" (explicada posteriormente) por exemplo, irá auxiliar no tratamento diferenciado às duas categorias dentro das políticas públicas de seu sistema. Estas distinções permeiam todo o trabalho do autor, tanto em sua descrição da natureza humana, como em sua ética, como em suas aplicações institucionais.

\footnotetext{
55 Doravante "Introduction"
} 


\subsection{Motivações na oferta e demanda de caridade}

Antes de apresentar as bases de sua teoria, como faz Bentham, é útil definir adequadamente dois termos que serão abundantemente utilizados para compreender as ideias do autor: prazer e dor. Prazer, define Bentham, é "qualquer sensação que um homem prefere sentir naquele instante do que sentir nenhuma" e dor é "qualquer sensação que um homem prefere não sentir à sentir” (BENTHAM apud DINWIDDY, 1989, p. 22). Estas definições chamam a atenção por algumas razões. Primeiro, a definição de "prazer" e "dor" são extremamente amplas, distintas do uso no vocabulário comum, uma vez que prazer incluí qualquer forma de bem-estar que seja, e dor qualquer forma de mal-estar ${ }^{56}$. Em segundo, embora prazer e dor sejam definidos por Bentham através uma relação de preferência, o próprio autor tem uma concepção cardinal de prazer e dor, com uma noção quantitativa que acompanha as preferências (e não ordinal, em que apenas a ordem preferências importam).

É desde a primeira frase de sua Introduction que Bentham declara como causas soberana das ações humanas, o prazer e a dor:

Nature has placed mankind under the governance of two sovereign masters, pain and pleasure. It is for them alone to point out what we ought to do, as well as to determine what we shall do (BENTHAM, 1843 [1789], p. 1).

Sua teoria de motivações, para uma ação qualquer que seja, contudo, possui detalhes específicos que merecem ser explorados. Primeiramente é necessário definir bem a palavra "motivo", que será usada por Bentham como "qualquer coisa que seja, que, por influenciar o arbítrio de um ser sensível [ao prazer e dor], é suposta como meio determinante para que ele aja, ou voluntariamente deixe de agir" (BENTHAM, 1843 [1789], p. 46). Assim, há uma amplitude de motivos de todas as ordens que podem ser considerados em uma ação, entretanto, todos eles são considerados através da lente do prazer e da dor. Um modo de compreender este ponto de vista é que Bentham concebe o cálculo através do prazer e da dor como parte da natureza humana, intrínseca, enquanto os motivos para uma ação podem ter qualquer origem, natural ou não (BENTHAM, 1843 [1789], p. 14). Por exemplo, a apresentação de uma música de um gênero específico que um indivíduo desfruta, é um motivo para que o indivíduo vá até o

${ }^{56}$ Curiosamente, esta amplitude na definição de prazer e dor vai contrária ao espírito geral da obra de Bentham em que termos específicos possuem definições pouco ambíguas, com o objetivo explícito de reduzir mal entendidos. As definições de prazer e dor, por outro lado, geram uma fácil confusão dada a usual interpretação puramente hedonista dos termos. 
concerto (sendo a apresentação, no caso, algo externo à natureza humana) - contudo, é apenas através da lente do prazer e da dor que o indivíduo avaliará se esta motivação lhe parece benéfica, e esta avaliação é parte estrutural do homem, e não de sua cultura.

O modo que a mente humana funciona, segundo Bentham, ao considerar uma ação qualquer, se dá através do seguinte processo: antes do ato, o indivíduo considera ${ }^{57}$ as consequências de uma ação, essa consideração lhe dará uma perspectiva ${ }^{58}$ do prazer e dor gerados pelas consequências de agir, e se a soma de prazeres superar a soma de dores, em sua avaliação, a ação é realizada (BENTHAM, 1843 [1789], p. 47). Isto não significa, de modo algum, que o indivíduo é necessariamente um bom avaliador das circunstâncias, visto que ele pode estar tanto consciente, como inconsciente ou ainda com uma falsa consciência em relação às reais circunstâncias que lhe cercam (BENTHAM, 1843 [1789], p. 35-36). Em última instância, contudo, o indivíduo é sempre motivado por interesses próprios, ainda que estes interesses próprios possam coincidir com interesses alheios: "Nesse sentido, a psicologia de Bentham é egoística, mas de modo algum elimina a possibilidade de conduta benevolente" (DINWIDDY, 1989, p. 22-23).

Dessa forma, exposto o modo sobre o qual se opera toda e qualquer ação humana, através de motivos avaliados pela lente da dor e do prazer, faz-se necessário compreender como o autor entende que avaliamos dores e prazeres, ou seja, quais são os tipos e circunstâncias que dão origem às mesmas. Em especial, para fins deste trabalho, quais as dores e prazeres relacionadas às ações que podemos considerar como originadas da "caridade", bem como as dores e prazeres relacionadas às circunstâncias de privação econômica e opulência. Bentham classifica as fontes (ou "sanções") de prazer e dor em quatro categorias principais: "a física, a política, a moral e a religiosa" (BENTHAM, 1843 [1789], p. 14).

A sanção física é a mais ordinária entre elas, e é definida pelo prazer ou dor causados por razões independentes da ação de outras pessoas ou Deus. Ela é considerada "natural", ou seja, é a fonte direta de prazer e dor sobre o indivíduo imposta pela natureza. A sanção política, por sua vez, é aquele prazer ou dor causado a um indivíduo por meio de um julgamento por parte de representante(s) da comunidade na forma do Estado - ela representa a influência das instituições formais sobre os indivíduos. A sanção moral (ou popular) é imposta sobre o indivíduo por outro, ou outros da comunidade, sem amparo legal - representa a influência de instituições informais sobre os indivíduos. A sanção religiosa representa prazeres e dores causados por Deus, seja nesta vida ou em uma vida futura. Enquanto as últimas três sanções

\footnotetext{
${ }^{57}$ A motivação no sentido "esse", anterior ao ato (causa).

58 A motivação no sentido "prospect", imaginativa das condições posteriores ao ato (consequência).
} 
podem ser separadas da sanção física para fins de legislação, por serem artificiais (no caso da sanção política e moral) ou sobrenaturais (no caso da religiosa), psicologicamente, todas sanções se manifestam sobre o indivíduo na forma da sanção "física", isto é, do prazer e dor que a natureza impõe pela sua própria condição humana:

\begin{abstract}
Of these four sanctions, the physical is altogether, we may observe, the ground-work of the political and the moral: so is it also of the religious, in as far as the latter bears relation to the present life. It is included in each of those other three. [...] In a word, the powers of nature may operate of themselves; but neither the magistrate, nor men at large, can operate, nor is God in the case in question supposed to operate, but through the powers of nature (BENTHAM, 1843 [1789], p. 15).
\end{abstract}

Dentro dessas sanções há ainda mais um nível de subcategorias específicas importantes para compreensão da ação humana segundo Bentham - os "tipos" de prazer e dor ${ }^{59}$. Os prazeres são listados e incluem: “[...] 2. Os prazeres da riqueza, [...] 8. Os prazeres da benevolência, [...] 14. Os prazeres do 'alívio"', que são os dois prazeres mais relevantes para o tema aqui em questão. De modo similar, as dores são listadas e incluem: “[...] 1. As dores da privação, [...] 7. As dores da benevolência" (BENTHAM, 1843 [1789], p. 17) ${ }^{60}$. Estes tipos de prazer e dores não excluem uns aos outros, isto é, estas "percepções de interesse" frequentemente são complexas, ocorrendo simultaneamente através de uma única causa. Por exemplo, o exercício de um ato de caridade pode, simultaneamente, gerar prazeres da benevolência e prazeres da religiosidade. Se excessivo, isto é, se algo de grande valor material ao próprio doador é transferido ao beneficiário da caridade, este mesmo ato potencialmente geraria também dores de privação ao doador (em conjunto com os demais prazeres).

Destacadas essas principais fontes de prazeres e dores no que se diz respeito ao ato da caridade, é possível utilizar o sistema de Bentham para deduzir se, via de regra, existe uma tendência humana a este tipo de ato ou se ele ocorre apenas em circunstâncias raras específicas.

Os prazeres da riqueza, isto é, a tendência de um homem a se sentir bem com a consciência da posse de bens materiais, é o obstáculo mais imediato ao exercício amplo da caridade. As dores da privação teriam o mesmo efeito. Todo e qualquer ato de caridade reduz a

\footnotetext{
${ }^{59}$ É curioso que Bentham se preocupe em separar prazeres e dores quando repetidamente é afirmado que eles são “a mesma coisa" em sentidos opostos (BENTHAM, 1843 [1789], p. 2, p. 4, p. 14). Talvez esta seja uma concessão prática, visto que dentro de sua filosofia muitos prazeres e dores poderiam ser agregados como fenômenos únicos. ${ }^{60}$ A lista completa de prazeres é a seguinte: "1. Os prazeres dos sentidos, 2. Os prazeres da riqueza, 3. Os prazeres da proficiência, 4. Os prazeres da amizade, 5. Os prazeres da boa reputação, 6. Os prazeres do poder, 7. Os prazeres da religiosidade, 8. Os prazeres da benevolência, 9. Os prazeres da malevolência, 10. Os prazeres da memória, 11. Os prazeres da imaginação, 12. Os prazeres da expectativa, 13. Os prazeres dependentes de associação, 14. Os prazeres do "alívio"”; e a lista completa das dores é a seguinte: "1. As dores da privação, 2. As dores dos sentidos, 3. As dores do constrangimento, 4. As dores da inimizade, 5. As dores de um má reputação, 6. As dores da religiosidade, 7. As dores da benevolência, 8. As dores da malevolência, 9. As dores da memória, 10. As dores da imaginação, 11. As dores da expectativa, 12. As dores dependentes de associação" (BENTHAM, 1843 [1789], p. 17).
} 
riqueza do doador, e, portanto, possui a tendência direta de gerar um motivo para não realizar a caridade: a consideração da perspectiva de redução dos prazeres de sua riqueza ou intensificação das dores de sua futura privação relativa.

Já os prazeres da benevolência, bem como as dores da benevolência, agem no sentido contrário, incentivando o ato de caridade. O que Bentham quer dizer com "prazeres da benevolência" e "dores da benevolência" é em realidade o fenômeno da simpatia, em um sentido similar ao de Smith:

The pleasures of benevolence are the pleasures resulting from the view of any pleasures
supposed to be possessed by the beings who may be the objects of benevolence; to wit,
the sensitive beings we are acquainted with; under which are commonly included, 1 .
The Supreme Being, 2. Human Beings, 3. Other animals. These may also be called the
pleasures of good-will, pleasures of sympathy, or the pleasures of the benevolent social
affections (BENTHAM, 1843 [1789], p. 18)

E do ponto de vista da dor:

The pains of benevolence are the pains resulting from the view of any pains supposed to be endured by other being. These may also be called the pains of good-will, of sympathy, or the pains of the benevolent and social affections (BENTHAM, 1843 [1789], p. 20)

Dessa forma, o motivo que nasce da presença natural dos sentimentos simpáticos do seres humanos é diretamente favorável a realização do ato de caridade: a consideração da perspectiva de prazer próprio que seria gerado ao supor que o receptor de um ato de caridade (uma classe específica de ato benevolente) sentiria prazer, bem como a consideração da perspectiva de dores próprias que seriam reduzidas relacionadas a percepção de que outros seres sentem dores, dores estas que poderiam ser reduzidas ou eliminadas por um ato de caridade. Este mecanismo simples de simpatia seria a "conexão entre a prudência e a benevolência" (BENTHAM apud BADER, 1975, p. 252), como Bentham explica em uma obra mais tardia (Deontology, 1834). Reforçando esta noção, Bader (1975) explica a benevolência com fins egoístas em Bentham:

By means of link this [between prudence and benevolence], the benevolent action produces a good for its doer. One does good to receive good, by means of 'resposive kindly sentiment': the love of the other (BADER, 1975, p. 252)

Existe mais uma fonte de prazeres e dores que, teoricamente, influenciaria os motivos de um indivíduo no sentido contrário a realização da caridade: a antipatia, na forma do "prazer da malevolência" e "dores da malevolência", que nada mais seria que o exato oposto do prazer 
da benevolência e dores da benevolência - isto é, o gosto de ver a dor de outros indivíduos, ou desgosto de ver prazer de outros indivíduos.

Este tipo de análise, do comportamento humano, técnica, baseada nas listas de dores e prazeres, é ainda muito simplificada em comparação com o verdadeiro funcionamento dos motivos para uma ação do ponto de vista de Bentham. Como já mencionado, estes prazeres e dores não são isolados uns dos outros, mas se conectam como uma rede complexa em que um pode ser correlacionado ou até mesmo a causa direta de outro - não só internamente a um indivíduo, mas entre indivíduos também. Os prazeres do "alívio", por exemplo, representam "prazeres baseados em dores", em que uma determinada dor é reduzida ou deixa de existir, gerando um prazer. No caso do ato de caridade, esse tipo de prazer não afeta diretamente a oferta de caridade, mas sim a demanda (o indivíduo que prevê um alívio em suas dores de privação age de modo a buscar caridade). Ainda assim, seria possível expandir a rede para mostrar como este tipo de prazer poderia influenciar a própria oferta de caridade: o potencial doador prevê o prazer do alívio alheio e, portanto, age buscando prazeres de benevolência (simpatia). Este tipo de análise, conectando as diversas fontes de prazeres e dores, para qualquer tipo de ato que seja, pode ser realizado ad infinitum: as dores de privação relacionadas à caridade poderiam estar conectadas com potenciais prazeres de religiosidade (satisfazendo a vontade de Deus e prevendo recompensas futuras), ou ainda com prazeres de boa reputação, ao mesmo tempo em que dores da imaginação podem ser simultaneamente ativadas, e assim em diante. A mente humana, em relação a perspectiva de dores e prazeres, é longe de ser simples do ponto de vista de Bentham.

Contudo, apesar desta complexidade, a sistematização do autor ainda é importante, sendo pelo menos duas as considerações que a justificam: primeiramente, ao descrever o "valor das dores e dos prazeres" para quaisquer grupos de pessoas, Bentham lista como fatores significativos do julgamento de um prazer ou dor qualquer "1. Sua intensidade, 2. Sua duração, 3. Sua certeza ou incerteza, 4. Sua proximidade ou afastamento, 5. Sua fecundidade, 6. Sua pureza, 7. Sua extensão" (BENTHAM, 1843 [1789], p. 16). Vários desses fatores tendem a ser reduzidos na medida em que os prazeres e dores se manifestam de modo indireto, e, portanto, um foco maior nos motivos mais diretos para uma ação é razoável. E em segundo lugar, o que Bentham realiza com esta sistematização de dores e prazeres humanos é a apresentação de um mecanismo pelo qual o legislador (e o economista político) pode avaliar suas propostas - sua preocupação é auxiliar a formulação de políticas adequadas, mais do que uma compreensão completa do todo da ação individual. É completamente possível, portanto, que conexões mais distantes entre dores e prazeres, gerem motivos complexos difíceis de serem completamente 
compreendidos em um nível analítico, entretanto, como uma ferramenta para estimação das melhores política públicas, uma aproximação melhor pode ser realizada com a sistematização apresentada. Malthus, por exemplo, ao explicitar que a caridade deve ser privada por certos motivos, inclui o próprio prazer do doador em um ato de caridade como justificativa (prazer ausente no caso em que o auxílio é realizado pelo Estado). Em consulta às extensas listas de Bentham, uma avaliação mais precisa da utilidade poderia ser realizada, para um julgamento mais adequado de qual deve ser a atitude do Estado em relação a uma atividade humana qualquer. A chance de esquecer um ou outro condicionante da utilidade para uma determinada política é significativa na ausência de um mecanismo como este fornecido por Bentham.

Até agora, a análise realizada de motivos para a ação de caridade representam apenas o "lado da oferta" de recursos aos indigentes. O lado da demanda, por sua vez, pode também ser compreendido através de uma análise dos motivos guiados pelo interesse de maximizar o prazer, ou, mais apropriadamente, minimizar a dor. Isto é, quais são os motivos que levam indivíduos a se colocar em uma posição em que estão efetivamente manifestando um pedido de auxílio explícito, ou ainda, implícito, isto é, indivíduos que não possuem outra escolha senão aceitar auxílio econômico a eles oferecido. Antes disso, contudo, é preciso realizar uma distinção semântica, a diferença entre "pobreza" e "indigência" no vocabulário de Bentham:

\begin{abstract}
Poverty is the state of everyone who, in order to obtain subsistence, is forced to have recourse to labour [...]. Poverty as above defined is the natural, the primitive, the general, the unchangeable, lot of man. The condition of persons whose poverty has placed them in what are termed opulent or easy circunstances, that is, who live upon the permanently recurring produce of labour already in store, is but an exception, which, under the most equal distribution of the stock thus laid up, could never, for any length of time, be very extensive. As labour is the source of wealth, so poverty is of labour. Banish poverty, you banish wealth (BENTHAM, 2001 [1797], p. 3).
\end{abstract}

Esta definição peculiar ao leitor contemporâneo pode gerar um grave mal entendimento semântico. Quando pensamos em pobreza, atualmente, estamos nos referindo a uma condição de privação significativa de recursos econômicos, relativa ou absoluta - independentemente da necessidade de exercer trabalho (ainda que, em geral, esta necessidade é inevitável em tais circunstâncias). A principal confusão que pode ser gerada é que Bentham parece completamente excluir a possibilidade que a pobreza possa ser erradicada, ou sequer enfrentada em grande escala. Claramente ele afirma isto, mas apenas no sentido próprio da palavra “pobreza", ou seja, Bentham está apenas afirmando que uma situação na qual nenhuma pessoa está em uma condição em que ela se sente impelida a realizar trabalho é impossível. A 
melhor palavra no vocabulário benthamita para descrever o que chamamos hoje de pobreza é "indigência", explicitamente diferenciada da "pobreza" no vocabulário do autor:

Indigence is the state of him who, being destitute of property [...], is at the same time either unable to labour, or unable, even for labour, to procure the supply of which he happens thus to be in want (BENTHAM, p. 3, 2001 [1797]).

Assim, apenas este estado de privação seria “o mal” a ser combatido, em que o indivíduo não consegue sustentar suas necessidades, seja pela incapacidade de realizar trabalho ou remuneração insuficiente - e não a "pobreza", daquele modo definido, que é inevitável e necessária. Bentham, portanto, considera como parte da demanda por caridade apenas a demanda realizada por indigentes, que é a que realmente importaria, e não por pobres.

Esta demanda seria influenciada por motivos condizentes com prazeres e dores já mencionados. As dores da privação (e seu oposto, o prazer da riqueza) seriam os incentivos mais diretos à busca por auxílio. Esta, contudo, é apenas um precursor às inevitáveis dores física da fome, do frio ou de doenças (incluídas nas "dores dos sentidos"), que resultam da condição de indigência. Se manifesta, neste caso, claramente a proposição de Bentham de que, todas as sanções culminam em sanções físicas, restritas ao sofrimento (ou prazer) do próprio indivíduo.

As fontes indiretas de demanda por caridade, por sua vez, são todos os prazeres que necessitam de um estado econômico suficiente para serem mais facilmente alcançados. Os prazeres do poder, prazeres da reputação, e mesmo os prazeres da benevolência podem ser citados como exemplos.

O quanto cada um desses prazeres e dores (derivados diretamente da natureza humana) influenciariam os indivíduos em uma sociedade dependeria de circunstâncias que afetam a sensibilidade a tais prazeres e dores, circunstâncias estas que podem ser tanto naturais como institucionais. Tal como no caso das muitas fontes de prazeres e dores, as circunstâncias são listadas extensivamente por Bentham $^{61}$. Cabe aqui, destacar as mais relevantes para a análise da oferta e demanda de caridade direcionada aos indigentes. Destacam-se: “1. Saúde, 2. Força, [...] 4. Imperfeição corporal, [...] 6. Força dos poderes intelectuais, [...] 14. Sensibilidade

61 “1. Saúde, 2. Força, 3. Resistência, 4. Imperfeição corporal, 5. Quantidade e qualidade de conhecimento, 6. Força de poderes intelectuais, 7. Firmeza mental, 8. Estabilidade mental, 9. Inclinações, 10. Sensibilidade moral, 11. Vieses morais, 12. Sensibilidade religiosa, 13. Vieses religiosos, 14. Sensibilidade simpática, 15. Vieses simpáticos, 16. Sensibilidade antipática, 17. Vieses antipáticos, 18. Insanidade, 19. Ocupações habituais, 20. Circunstâncias pecuniárias, 21. Conexões simpáticas, 22. Conexões antipáticas, 23. Estrutura original do corpo, 24. Estrutura original da mente, 25. Sexo, 26. Idade, 27. Classe, 28. Educação, 29. Clima, 30. Raça, 31. Governo, 32. Filiação religiosa" (BENTHAM, 1843 [1789], p. 22). Tal como no caso da lista de prazeres e dores, as influências sobre a caridade podem ser encontradas em praticamente todos os itens da lista se conexões indiretas forem realizadas, contudo, são as conexões diretas com a geração de motivos para ofertar ou demandar caridade que são as mais significantes. 
simpática, 15. Vieses simpáticos, [...] 18. Insanidade, [...] 20. Circunstâncias pecuniárias, 21. Conexões simpáticas" (BENTHAM, 1843 [1789], p. 22).

Do lado da oferta de caridade as circunstâncias relacionadas à simpatia são as mais relevantes. A sensibilidade simpática é a "propensão que um homem possui de obter prazer da felicidade, ou obter dor da infelicidade alheia" (BENTHAM, 1843 [1789], p. 24-25). Naturalmente, indivíduos com maior sensibilidade simpática têm maior propensão em realizar caridade, com o interesse de mitigar o sofrimento de indigentes. O viés simpático, por sua vez, faz referência a que grupos a simpatia de um homem tende a ser direcionada, podendo ser bastante específica (para certos indivíduos) ou para uma classe de indivíduos, ou ainda para o todo da nação, o todo da humanidade ou, em um caso mais extremos até mesmo incluindo todas criaturas sensíveis (BENTHAM, 1843 [1789], p. 25). Haveria, no caso, um ponto ótimo em que o viés simpático tende a maximizar a caridade à indigentes - se muito restrito a indivíduos próximos ou ampla demais a ponto de ser direcionadas a pessoas e animais fora do escopo mais adequado da caridade (indigência), o viés tende a reduzir a oferta significante de caridade. Se, contudo, o viés simpático tem um escopo comunitário, ou, de modo ainda mais específico, focado na classe de indigentes especificamente, a oferta de caridade significante se elevaria bastante. Note que, as observações de Smith quanto aos fracos sentimentos simpáticos em relação aos pobres é uma expansão detalhada deste ponto (com a conclusão de que nossos viés simpático é pouco direcionado a eles, e mais direcionado as pessoas com maior sucesso). Já as “conexões simpáticas” se referem especificamente às já consolidadas relações sociais que um indivíduo possui que garantem um viés simpático estabelecido. Em geral, as conexões simpáticas com a família e amigos íntimos é um fenômeno natural, ainda que estas conexões possam ser expandidas ao longo de sua vida para contemplar indivíduos mais distantes (BENTHAM, 1843 [1789], p. 26). De certa forma, Bentham está afirmando aqui que, graças as conexões simpáticas naturais, há uma tendência de que o viés simpático seja mais restrito do que o princípio da utilidade (explorado na seção seguinte) recomendaria. Todas estas circunstâncias afetam as motivações para a oferta da caridade ao alterar a sensibilidade dos prazeres e dores simpáticos.

Outro aspecto que afeta diretamente a oferta de caridade são as circunstâncias pecuniárias de um indivíduo. Este termo é definido de modo bastante preciso: "sob a categoria de circunstâncias pecuniárias, eu quero evidenciar a proporção dos meios de um homem em relação as suas demandas" (BENTHAM, 1843 [1789], p. 25). Os meios de um homem sendo definidos por toda sua propriedade, rendimentos e auxílio recebido, e suas demandas sendo definidas por seus gastos habituais, gastos com suas conexões pessoais, demandas casuais, e 
expectativas. Na medida em que os meios de um homem superam as suas demandas, mais recursos podem ser direcionados à caridade.

Aqui é importante interromper a análise para uma observação relevante. Qual seria o balanço natural entre os prazeres simpáticos e os prazeres auto direcionados? A resposta de Bentham é que os motivos derivados de prazeres auto direcionados são, via de regra, mais fortes:

Now the motives, whereof the influence is at once most powerful, most constant, and most extensive, are the motives of physical desire, the love of wealth, the love of ease, the love of life, and the fear of pain: all of them self-regarding motives (BENTHAM, 1843 [1789], p. 75)

Esse ponto é reforçado pelo fato de que Bentham entendia os sentimentos simpáticos como tipos de prazer e dores tão diferentes dos prazeres e dores auto direcionados, que talvez merecessem sua própria classificação especial como uma sanção diferente da sanção física, criando uma quinta sanção, a "simpática"62 - excepcional, rara, e que, em geral, as sanções físicas que refletiam as preferências próprias são tão mais fortes que sua superioridade “deveria ser tratada como um fato básico da natureza humana para propósitos de legislação e administração social” (DINWIDDY, 1989, p. 25).

Os aspectos de circunstâncias que afetam a demanda da caridade, por sua vez, são expressos de modo mais detalhado em sua obra dedicada à NCC (Tracts on the Poor Laws), tratadas na última seção de Bentham, e encaixam-se em parte com estas circunstâncias listadas na Introduction. Fundamentalmente, a demanda de caridade por indigentes é definida essencialmente pelas circunstâncias pecuniárias adversas de um indivíduo já pobre ou incapaz, que o tornam indigente. Contudo, esta circunstância é por definição, determinante da demanda por auxílio. Ao tratar das circunstâncias, refere-se às influências estariam relacionadas a própria incapacidade de um indivíduo de obter meios para se sustentar. Falta de saúde, fraqueza física ou deformidade corporal séria incluem-se nestas circunstâncias. De modo similar, fraqueza intelectual debilitante ou insanidade também podem impedir que meios econômicos sejam obtidos para sustento das necessidades básicas.

Outras circunstâncias como "25. Sexo, 26. Idade, 27. Classe, 28. Educação, 29. Clima, 30. Raça, 31. Governo, 32. Filiação religiosa" também influenciam sensibilidades a prazeres e dores relevantes à oferta e demanda de caridade, mas indiretamente, através da influência sobre as outras circunstâncias citadas. Por exemplo, Bentham afirma que enquanto a sensibilidade simpática de uma mulher tende a ser mais intensa de o que a de um homem, seu viés simpático

\footnotetext{
${ }^{62}$ Intenção expressa em sua obra mais tardia Deontologia (DINWIDDY, 1989, p. 24).
} 
raramente se expande para o todo da comunidade, sendo muito mais fortemente direcionado a seus filhos do que no caso masculino - esta seria uma circunstância que afeta a oferta de caridade (reduzindo-a) ${ }^{63}$. Quanto à idade, Bentham indica por exemplo que os períodos da infância e decrepitude fazem do indivíduo invariavelmente "menos saudável, mais fraco, menos resistente e assim em diante" (BENTHAM, 1843 [1789], p. 28), e, tal como no caso do sexo, é uma circunstância que afeta outras circunstâncias relevantes na consideração de sensibilidades ao prazer e dor - no caso, elevando a demanda de caridade.

Em suma, os aspectos que incentivam a caridade no sistema egoístico de Bentham são restritos aos motivos influenciados por prazeres e dores simpáticas, ainda potencialmente restritos por circunstâncias que podem reduzir a sensibilidade simpática ou direcioná-la para classes outras que não indigentes. Ao mesmo tempo, os motivos para obter caridade, se as circunstâncias pecuniárias de um indivíduo o colocam em situação de indigência, são quase todas dores e prazeres auto direcionadas, que além de numerosas, seriam naturalmente mais poderosas segundo o autor. Como se pode perceber, dentro desta quantificação de motivos para ofertar ou demandar caridade é possível concluir que, dentro das estruturas de comportamento humano de Bentham, a oferta de caridade tende a ser menor que a demanda. Não há como esperar que as pessoas em circunstâncias mais favoráveis supram por completo as necessidades que caracterizam a indigência. Esta conclusão é expressada mais diretamente em um trecho de seus escritos (Writings on the Poor Laws):

[...] the supply afforded by the rich proprietor would be proportional not to the demand of the necessities, but to his own conception of his own superfluities: he would give as much as decency in his estimation prescribed, or which in his estimate would be the same thing, humanity demanded; (...) he has given a great deal, as much as ever he could spare: if it failed being sufficient he is sorry for it, but he can do no more (BENTHAM, 2001 [1797], p. 13).

Bentham reforça esta conclusão não só apelando para a falta de incentivo privado na oferta, mas também para argumentos empíricos. Não é apenas na Inglaterra, afirma o autor, que este déficit de caridade existe, outras nações, a França citada como exemplo, também apresentam tal insuficiência (BENTHAM, 2001 [1797], p. 15).

\footnotetext{
${ }^{63}$ Em termos mais gerais Bentham indica quanto ao comportamento simpático feminino: “seus vieses simpáticos tendem a se adequar menos ao princípio da utilidade do que o dos homens” (BENTHAM, 1843 [1789], p. 28).
} 


\subsection{O Princípio da Utilidade e o papel do legislador}

Compreendidos os motivos para ação humana relacionados à caridade em Bentham, fazse necessário uma análise de sua teoria moral, que justificará, na visão do autor, que a presença da indigência é um problema fundamental que deveria (moralmente) ser enfrentado pela sociedade. Sua visão é calcada por completo no chamado "princípio da utilidade":

[...] By principle of utility is meant that principle which approves or disapproves of every action whatsoever, according to the tendency which it appears to have to augment or diminish the happiness of the party whose interest is in question. [...] if that party be the community in general, then the happiness of the community; if a particular individual, then the happiness of that individual (BENTHAM, 1843 [1789], p. 1-2).

É a partir desta regra, e apenas desta regra, que Bentham considera correto julgar o que é certo ou errado. E, apesar de apresentar bons motivos para adota-la, o próprio autor admite que não há demonstração de que esta é a definição de certo ou errado - ela é o seu ponto de partida, seu axioma básico, e não requer uma prova (BENTHAM, 1843 [1789], p. 2). Algumas observações iniciais importantes são necessárias para a compreensão adequada do princípio da utilidade. Primeiramente, a palavra "felicidade" é aqui sinônima a "benefício, vantagem, prazer, bem” (BENTHAM, 1843 [1789], p. 1-2). Esta ambiguidade semântica (não característica de Bentham) reflete em parte outro aspecto importante de seus valores morais baseados no princípio da utilidade: nenhuma fonte ou tipo de prazer e dor são superiores ou inferiores em relação aos demais - todos os prazeres e dores são somados simultaneamente em um cálculo utilitário que rejeita noções que distinguem qualitativamente ações que levem em conta "a vontade de Deus" ou que "a moralidade, que nós racionalmente intuímos nosso dever, que julgamos a conduta através de um senso moral comum" (FIESER, 2001, p. 194), "para Bentham algumas destas doutrinas são sem sentido, e outras irrelevantes" (FIESER, 2001, p. 194). Em outras palavras, embora estas noções influenciem o comportamento do indivíduo e possam ser fontes de prazer e dores que devem ser avaliadas no cálculo moral, elas não são, a priori, fontes de moralidade de ordem superior a quaisquer outras causas de prazer (e minimização de dor). De certa forma, a prescrição moral benthamita é simples, direta, e não leva em conta princípios secundários fora do princípio da utilidade (DIAS, 2011, p. 44).

De fato, Bentham expressa que invariavelmente a única posição consistente de um ponto de vista moral é o princípio da utilidade. Outras manifestações morais, frequentemente, seriam o próprio princípio da utilidade em disfarce. Por exemplo, uma doutrina religiosa que afirma que um certo conjunto de ações é recomendável e outro conjunto não é, pois, o indivíduo que 
exerce ações do primeiro grupo será recompensado no céu, enquanto indivíduos do segundo grupo serão enviados para sofrer no inferno, estaria apenas atrasando uma execução final do prazer e da dor, que ainda agem como árbitros finais daquilo que é certo ou errado, ou seja, Deus estaria adotando o princípio da utilidade como forma de recompensa e punição, pois reconhece-se que é isto que importa ao indivíduo. Para Bentham a utilidade determina o que é certo e errado, e, a partir daí, isso pode ser interpretado como a vontade de Deus, e não o oposto $^{64}$ (BENTHAM, 1843 [1789], p. 11). Contudo, nem todos os sistemas morais são manifestações disfarçadas do princípio da utilidade. Bentham identifica dois sistemas morais possíveis que são divergentes: o princípio do ascetismo e o princípio da simpatia e antipatia. $\mathrm{O}$ primeiro, asceticismo, seria exatamente o oposto do princípio da utilidade, ou seja, a afirmação de que o que é certo é aquilo que reduz o prazer e aumenta a dor. Na medida em que ele é adotado, ele não é, nunca, adotado de modo consistente e por completo, e o pouco de sua influência tenderia a tornar o homem miserável (BENTHAM, 1843 [1789], p. 5). O asceticismo em um sentido diverso, no sentido de sacrifício presente ou incerto para obtenção de benefícios futuros, dispersos ou certos, novamente é um mero disfarce do princípio da utilidade. Já o princípio da simpatia e antipatia se refere a noção de que o que é certo e errado é determinado "meramente por que um homem se encontra disposto a aprovar ou desaprovar [certas ações]" (BENTHAM, 1843 [1789], p. 7-8). Este, não seria um princípio, mas sim uma "negação de qualquer princípio", sendo completamente arbitrário e variável - impossível de se adequar para algo que deve ser implementado coletivamente, como princípios legislativos ou políticas públicas.

Um segundo aspecto importante da definição do princípio da utilidade fornecido por Bentham é o destaque dos termos "comunidade" ou "indivíduo", ou de modo mais geral "do sujeito a qual o interesse está em questão". Uma interpretação possível é que Bentham deixa isso intencionalmente aberto para que o princípio seja adaptável a situações diferentes. Em certos contextos, a classe afetada por uma ação é mais circunscrita que em outros contextos, certas ações devem levar em conta o bem estar da família por ela ser o único objeto afetado significantemente pela ação, enquanto outras de toda a comunidade, ou ainda outras ações potencialmente afetariam toda a humanidade. Bentham estaria primariamente preocupado com a legislação em um nível nacional ou regional, e, portanto, preferiu utilizar o termo "comunidade" mais frequente, ainda que "ele estivesse consciente de que outros pontos de

${ }^{64}$ É curioso como esta é uma noção inversa a interpretação teológica de Malthus. Para Malthus, a vontade de Deus determina o que é certo e errado, e ela se revela através da utilidade. Para Bentham, a utilidade determina o que é certo e errado, e seria possível a conjectura de que o próprio Deus adota o princípio da utilidade. 
referência são possíveis" (DINWIDDY, 1989, p. 27). O ponto de vista de "cidadão do mundo", por exemplo, teria sido adotado por Bentham em seus escritos sobre lei internacional (DINWIDDY, 1989, p. 27). O objetivo de Bentham era informar o legislador, e, portanto, um ponto de vista amplo (da comunidade, normalmente) precisaria ser adotado, para entender o objetivo de Bentham, é necessário conectar a sua teoria comportamental com sua teoria ética.

Como já foi mencionado, há uma dualidade no comportamento humano: os motivos para um ato variam de acordo com o ambiente em que o indivíduo se encontra, ao passo que a interpretação do indivíduo dessas motivações se dá através de uma lei natural rígida, que é a percepção do que gera prazer e dor para si mesmo. Dessa forma, enquanto é impossível alterar a lente do prazer e da dor sob as quais as decisões humanas são tomadas, é completamente possível e recomendável influenciar os motivos, o ambiente, em que estes indivíduos auto interessados tomam suas decisões. Ou seja, moldar as instituições de modo a influenciar o comportamento das pessoas para que estes se adequassem o máximo possível ao princípio da utilidade. Mais especificamente das instituições formais que poderiam exercer sanções políticas, as sanções física, moral e religiosa estariam fora do controle direto do legislador. Não faria sentido, dentro do sistema comportamental apresentado, uma atitude moralizante em relação ao indivíduo. Este estava preso pelas amarras do prazer e dor, e, de certa forma, não possuía verdadeiro livre arbítrio em uma interpretação forte da expressão. O princípio da utilidade, portanto, era principalmente direcionado ao legislador - ou mais precisamente à legislação em si (DINWIDDY, 1989, p. 29-30), ou ainda, "não há diferença entre de natureza entre o conteúdo das regras que constam na ética e na legislação" (DIAS, 2011, p. 274), a legislação deve refletir fielmente a busca pelo princípio da utilidade. Para Bentham, o que impede os legisladores de realizar um bom trabalho, via de regra, não é uma ativa negação do princípio da utilidade em si, mas sim de uma incapacidade intelectual ou falta de informação para realizar políticas que se adequem a este princípio: "se em qualquer momento [políticos] fizeram sofrer a nação despojada de enxames de pensionistas ociosos, burocratas inúteis, foi mais por negligência e imbecilidade, do que qualquer plano acordado de oprimir e pilhar a nação" (BENTHAM, 1843 [1789], p. 5). A preocupação de Bentham, portanto, não é convencer o leitor o individual de que o princípio da utilidade é adequado, pois isso é já evidente e inevitável, se comparado aos demais princípios morais possíveis. Sua preocupação é convencer o legislador a utilizar um método racional - fornecido por ele, Bentham - para alcançar arranjos institucionais da sociedade que permitam uma maior proximidade do princípio da utilidade. Por exemplo, estes poderiam se manifestar de forma a "culpar" ou "recompensar" certos atos específicos de indivíduos, dando motivos, na forma de prazer e dor, para ações que expandam 
o prazer e minimizem a dor da comunidade. Do ponto de vista social, essa é a missão da legislação, do bom governo. Do ponto de vista de um indivíduo, é ingênua a atitude moralista que espera que outros atuem de acordo com um princípio moral qualquer, quando em realidade todos são comandados pela causa final da busca do prazer e fuga da dor.

Como toda esta discussão se adequa ao tema da caridade e o papel de instituições públicas na questão da indigência? Para Bentham, a resposta é simples: há uma obrigação moral em reduzir o sofrimento relacionado à indigência, em reduzir as ineficiências da ociosidade e gerar conforto e segurança a comunidade com políticas que removam das ruas indivíduos em precária situação econômica. De fato, apesar significante no cálculo utilitário o sofrimento dos próprios indigentes, não se deveria subestimar os potenciais benefícios sociais mais amplos que a redução da indigência proporcionaria (ou, o que é a mesma coisa, as dores à comunidade que sua continuidade causa) - esta parte do argumento, em realidade, é mais significante ainda para Bentham:

If compassion for the indigent themselves were not sufficient warrant for the continuing provision made for the relief on the steady basis of public contribution, regard for the security of the affluent would of itself be sufficient to forbid the abolition of it (BENTHAM, 2001 [1797], p. 19).

E, portanto, uma abolição da Lei dos Pobres (como propunha Malthus) seria desastrosa na medida em que o problema da indigência se tornaria ainda maior (em termos quantitativos, o déficit entre a demanda e a oferta de caridade se elevaria ainda mais). Bentham, contudo, não estaria satisfeito com as condições então estabelecidas, uma vez que a segurança da comunidade estaria necessariamente ameaçada pela presença de indigentes em liberdade. Segundo Bentham, não há outra opção viável ao indigente desesperado, senão a violência, uma vez que o auxílio voluntário é insuficiente, pois "quando um homem não tem nenhuma outra opção além de roubar ou morrer de fome, a escolha não pode ser considerada incerta: raramente há dúvida de qual lado das alternativas ser escolhido" (BENTHAM, 2001 [1797], p. 19).

Dessa forma, para Bentham, através do princípio da utilidade, é clara a necessidade moral de agir. Dada a certeza de que fundos privados serão insuficientes, ou seja, de que a oferta de caridade é sempre menor que a demanda, cabe ao legislador enfrentar o problema. A questão, apesar de ser preponderantemente um problema de quantidade de auxílio voluntário oferecido, também apresentaria problemas de alocação se deixada à livre iniciativa. Bentham explica, por exemplo, que o incentivo daqueles que oferecem caridade, muitas vezes motivados pela dor 
simpática em relação ao indigente, tenderia a favorecer aqueles que demonstram mais dor, e não aqueles que realmente a sofrem ${ }^{65}$ :

[...] pain is there [in street begging] the engine, and the only engine, by which relief can be extracted, and the beggar who by any means whatever can contrive to produce the most pain will fare the best. The dole of the passenger will accordingly be the prey of the best actor, or of him who can contrive to inspire most disgust, [...] not to him whose necessities are most urgent (BENTHAM, 2001 [1797], p. 14).

A tendência de alocação e a quantidade necessária de auxílio, sem interferência política, seriam demasiadas distantes do objetivo proposto pelo princípio da utilidade. A solução proposta por Bentham teria que ser uma que não só levasse em conta o problema da falta de quantidade de auxílio, mas como os fundos seriam distribuídos de modo eficiente.

É importante destacar, contudo, que Bentham não está essencialmente preocupado com uma distribuição igualitária de recursos (em princípio) e nem mesmo de utilidade. Adequar-se ao princípio da utilidade significaria um aumento da felicidade agregada, sendo completamente possível que a condição de uma pessoa extremamente afortunada fosse suficiente para compensar os leves infortúnios de duas outras, por exemplo (DINWIDDY, 1989, p. 26). Isso significaria, que, em seus planos (como veremos na NCC), não há uma preocupação em aproximar a qualidade de vida dos indigentes de não indigentes - para Bentham, se a qualidade de vida dos indigentes se mantivesse no mesmo patamar e o resto da sociedade ganhasse com isso, o plano seria bem sucedido. Em casos mais extremos, se alguns indigentes estivessem em situação pior, mas isso fosse compensado por um aumento da felicidade da comunidade desproporcionalmente maior, ainda valeria a pena do ponto de vista do princípio da utilidade.

Esta falta de preocupação, em princípio, com a igualdade, manifesta o império absoluto do princípio da utilidade não corrompido por outras considerações morais. Entretanto, se em princípio a distribuição de recursos e de utilidade não era necessariamente algo obrigatório para que o legislador pudesse cumprir suas obrigações morais, pragmaticamente, políticas com ideais igualitários poderiam ser mais adequadas em maximizar a felicidade agregada (DINWIDDY, 1989, p. 26-27). Isto ocorreria por causa do fenômeno da utilidade marginal decrescente do dinheiro, do qual Bentham estava já completamente ciente (DINWIDDY, 1989, p. 52):

The effect of wealth in the production of happiness goes on diminishing, as the quantity by which the wealth of one man exceeds that of another goes on increasing: in other words, the quantity of happiness produced by a particle of wealth (each particle being

\footnotetext{
${ }^{65}$ Curiosamente, neste ponto Bentham é quase idêntico a Malthus (e oposto a Smith), apesar de suas conclusões diametralmente opostas.
} 
of the same magnitude) will be less and less at every particle (BENTHAM, 1843 [1831], p. 229)

Por essa razão mesmo que, a partir de 1831, Bentham passava a incluir em seu princípio da utilidade sua "meta ideal: a provisão de uma quantidade igual de felicidade a todos" (DINWIDDY, 1989, p. 27).

Contudo, esta mudança de atitude em relação a seus escritos anteriores (causada possivelmente por razões intelectuais como pessoais na vida de Bentham, como veremos no capítulo seguinte), ocorreria em uma fase posterior a seus escritos sobre a NCC, que têm data de publicação de 1817. Ainda assim, ao elaborar a NCC, há uma intenção de Bentham de melhorar a qualidade de vida tanto dos indigentes (em especial as classes de indigentes que se encontram nestas condição por circunstâncias fora de seu controle ${ }^{66}$ ), quanto da comunidade como um todo. Ao menos em teoria.

\subsection{Instituições e a National Charity Company}

Nesta seção são tratados os planos concretos de Bentham para eliminar a indigência por meio da NCC, bem como sua atitude geral ao papel das instituições e como elas se relacionam com o princípio da utilidade.

\subsubsection{Estrutura geral da NCC}

Quais seriam os detalhes específicos do funcionamento da NCC? E como eles são uma melhora em relação ao sistema da Lei dos Pobres?

A NCC era um projeto ainda mais ambicioso que o seu famoso Panopticon. Em termos físicos-estruturais, a NCC seria composta inicialmente por 250 casas de trabalho para 250.000

\footnotetext{
${ }^{66}$ A razão pela qual a uma diferenciação entre indigentes por circunstâncias fora de seu controle e indigentes que possuem certa responsabilidade pela sua condição precária, é relacionada a criação de incentivos adequados para o bom funcionamento da sociedade, isto é, é necessário diferenciá-los e trata-los de modo diferente para que exista um incentivo maior de evitar a condição de indigência, que prejudica a sociedade como um todo. Não há aqui, portanto, uma diferenciação de Bentham quanto ao prazer ou dor de um tipo de indigente ser fundamentalmente mais relevante do que o prazer ou dor de outro tipo.
} 
indigentes (BENTHAM, 1843 [1797], p. 369), podendo chegar a 500 casas com 1.000 .000 de indivíduos para solucionar o problema da indigência na Inglaterra toda (HIMMELFARB, 1970, p. 83). Em termos administrativos, a NCC seria um enorme monopólio privado de capital aberto com esta condição garantida pelo governo - a NCC seria uma instituição comparável em importância e administração à Companhia das Índias Orientais ou ao Banco da Inglaterra (BENTHAM, 1843 [1797], p. 369). As razões para esta estrutura e tamanho podem ser resumidos em quatro grandes princípios organizados por Himmelfarb (1970) que parecem ser fundamentais para entender a NCC.

O primeiro princípio seria o "princípio do interesse", ou seja, o interesse privado dos donos da Companhia e das casas de trabalho garantiria o bom funcionamento da NCC (HIMMELFARB, 1970, p. 83). A justificativa para a necessidade da autoridade ser privada, e, o que é mais importante, aferir lucros através do funcionamento da NCC, é justamente o reconhecimento por parte de Bentham de que os administradores da NCC seriam naturalmente guiados pelos seus próprios interesses - pela busca de prazeres, que, por sua vez, seriam predominantemente relacionados à prazeres auto direcionados. O princípio do interesse não é restrito ao comportamento esperado dos administradores, mas dos indigentes dentro da NCC também. É por essa razão que Bentham propõe um sistema cuidadoso de méritos e recompensas, bem como deméritos e punições, gerando "motivos" para o bom trabalho e comportamento dentro das casas (BENTHAM, 1843 [1797], p. 380). É nítida a influência da visão de natureza humana de Bentham na estruturação de seus projetos, como a NCC e o Panopticon.

O segundo princípio seria o "princípio da publicidade", isto é, a necessidade de que, para contrabalancear os impulsos egoístas de seus administradores, a NCC fosse aberta a fiscalização do público e do governo para prevenir abusos aos residentes das casas de trabalho (BENTHAM, 1843 [1797], p. 381). Além de visitações propriamente ditas, a NCC manteria registros que garantissem o bom funcionamento não apenas em termos de tratamento adequado dos indigentes, mas também em termos de eficiência (uma vez que, como veremos, a instituição seria amplamente subsidiada pelo Estado). Registros de reclamações de indigentes, comportamento, punição e mérito, seriam utilizados para garantir a justiça dentro da NCC. Vale mencionar que, quando necessário, as casas de trabalho serviriam como prisões de caráter punitivo, e, para isso, a fiscalização do legislador e do público seriam essenciais (HIMMELFARB, 1970, p. 86).

O terceiro princípio de funcionamento da NCC é o "princípio da centralização e monopólio". Como já mencionado, a NCC não teria concorrência com outras instituições 
similares. Mas Bentham propõe mais que apenas um monopólio para este tipo de instituição - para o autor, a NCC seria a única instituição em todo país autorizada a realizar atividades de auxílio (HIMMELFARB, 1970, p. 87-88). Bentham estaria propondo "abolição total do outdoor relief" (HIMMELFARB, 1970, p. 88), tornando clara a divisão entre o pobre independente e o indigente que recebe auxílio público (“pauper"). Assim, as atividades de auxílio seriam completamente centralizadas em uma única autoridade, e não em várias paróquias como no caso da Lei dos Pobres. O processo de centralização traria, segundo Bentham, a solução a um sério problema: as divergências na prosperidade e generosidade de regiões distintas causariam um fluxo insustentável de indigentes para algumas regiões em particular, criando um desincentivo à própria generosidade tanto das paróquias como dos indivíduos dispostos em realizar caridade nas mesmas (BENTHAM, 2001 [1797], p. 13-14). Em outras palavras, até mesmo a caridade privada se via prejudicada com a descentralização do auxílio subsidiado pelo Estado através das paróquias ${ }^{67}$. O que Bentham torna explícito é que, se direcionada à NCC, a caridade privada seria utilizada de modo muito mais eficiente e sem gerar quaisquer distorções devido às diferenças de riqueza regionais:

Bourne aloft upon the platform of public charity, what private charity gains thus in power, is like what the dwarf acquired in prospect, when mounted on the giant's shoulder (BENTHAM, 1843 [1797], p. 429).

Dada a centralização proposta, a magnitude da NCC seria significativa como já mencionado. É justamente por causa deste tamanho expressivo proposto por Bentham que a perspectiva de realização do projeto por meios dos cofres públicos faria da ideia custosa demais à sociedade. A solução seria tornar a NCC uma empresa de capital aberto, para que os vultuosos investimentos necessários para sua estruturação e funcionamento fossem obtidos através do setor privado. O princípio do interesse garantiria o retorno dos investimentos.

\footnotetext{
${ }^{67}$ A questão da centralização/descentralização do auxílio é interessante em termos comparativos com Malthus e Smith. Uma primeira observação a ser realizada é que Bentham está aqui propondo uma solução ao único problema apontado explicitamente por Smith à Lei dos Pobres: as distorções de mobilidade de trabalho não estariam mais presentes sob o sistema da NCC - parece, contudo, extremamente improvável que tal solução monopolística e total possa ser encaixada na visão de mundo de Smith. Quanto às comparações com Malthus, é interessante notar que Malthus (em sua metáfora do banquete) levanta esta mesma questão de Benhtam, isto é, a generosidade excessiva atraí uma quantidade insustentável de indigentes transformando opulência em miséria. Para Malthus, este é um sinal de que a generosidade deve ser cuidadosa, limitada, privada e bem direcionada. Para Bentham, a solução é oposta, a generosidade deve ser ampliada e centralizada de tal modo que nenhuma região sofra as consequências negativas de sua própria prosperidade. De certa forma, ambos veem a Lei dos Pobres como uma política incompleta, que precisa ou ser abolida (Malthus), ou substituída por uma política completa (Bentham). No momento em que tanto Bentham como Malthus se preocupavam com o tema, uma legislação referente a Lei dos Pobres havia sido proposta, ("Pitt's Poor Law Bill of 1796), que expandiria generosamente o auxílio, sendo considerada muito progressiva - no que se refere a esta lei, tanto Malthus como Bentham foram ferrenhos críticos, ambos atacando-a com motivos não tão diferentes, motivos muito baseados na suas respectivas perspectivas de natureza humana, apesar de conclusões diametralmente opostas (HIMMELFARB, 1970, p. 118-120)
} 
O quarto princípio identificado por Himmelfarb (1970) na NCC é o "princípio da coerção", que se articula diretamente com o princípio da centralização. Com a implementação da NCC, e a consequente eliminação de outras formas de auxílio (como o outdoor relief), o incentivo para mendicância aumentaria ainda mais:

If, notwithstanding the adoption of the proposed system in other respects [the NCC], begging were to be tolerated, the nuisance would be much greater than at the present: since, of those who are now maintained in idleness in the character of paupers, multitudes, rather than be set to work, would become beggars (BENTHAM, 1843 [1797], p. 401).

Assim, necessidade de medidas coercitivas para impedir uma proliferação de crimes e pedintes se tornaria clara. Para o sucesso do projeto, a proibição da mendicância e a autoridade para aprisionar (na NCC) aqueles que a realizassem era a solução “indispensável” (BENTHAM, 1843 [1797], p. 401). Vale ressaltar, a atitude coercitiva não seria apenas um "poder" da NCC, mas sim um dever para com o público (BENTHAM, 1843 [1797], p. 370-371). Isto por que os males causados pela mendicância à sociedade não seriam poucos: a geração inconveniente da "dor da simpatia" aos pedestres, o "desgosto" quando a simpatia não se manifesta, o "desencorajamento ao trabalho" que cresce com cada ato de caridade a um mendigo que obtém itens de consumo sem nenhum sacrifício ${ }^{68}$, a “facilitação aos crimes" relacionada a perda da sensação de vergonha inata em cada um que desaparece com a mendicância (BENTHAM, 1843 [1797], p. 401). E, por fim, a coerção também se justifica pela melhoria da condição do próprio mendigo, que não possui em si a força de vontade ou capacidade de sair de sua condição de pedinte:

For one prosperous and happy beggar, there are probably many unprosperous and miserable ones; wretches who, notwithstanding, keep lingering in their wretchedness; sometimes for want of power, sometimes for want of resolution, to emerge of it (BENTHAM, 1843 [1797], p. 401).

Entretanto perda de liberdade daqueles compulsoriamente mantidos na NCC não é justificada apenas pelo próprio bem do mendigo, mas também pelo benefício da sociedade como um todo. Como Himmelfarb indica, o uso da força é justificado preponderantemente "não para o benefício da pessoa que perderá a liberdade” (HIMMELFARB, 1970, p. 93). Manifestase aqui, portanto, a noção de Bentham de que o que importa realmente na criação de instituições que busquem respeitar o princípio da utilidade é a soma total de prazeres e dores, e não direitos

\footnotetext{
${ }^{68}$ Como indica Stokes (2001, p. 714): “Caridade privada, para Bentham, não ocorre em um ambiente especial separado do mercado, mas interfere deteriorando o mercado de trabalho".
} 
individuais. A evidência mais direta é que Bentham reconhece que, em alguns casos particulares, existem "mendigos prósperos e felizes" em sua condição, mas sendo uma minoria e causando os muitos males já mencionados, sua liberdade não se justifica (BENTHAM, 1843 [1797], p. 401).

O plano para a reclusão dos mendigos daria poder e recompensa para qualquer pessoa apreender mendigos e leva-los às autoridades, bem como recompensas a informantes que denunciassem mendigos e assim ajudassem em sua apreensão, com destino à NCC. Contudo, Bentham não defende a ideia de punir aqueles que realizam doações a mendigos na rua, pela impopularidade e improdutividade da ideia, pois seria um desincentivo aos doadores de produzir evidência contra os mendigos se necessário (BENTHAM, 1983 [1797], p. 402).

Esta preocupação de Bentham com a mendicância em particular encontra bases não só em seus escritos sobre a NCC e a Lei dos Pobres. Já na própria Introduction, Bentham caracteriza a "ociosidadade", como "a mãe do vício e da miséria"69 (BENTHAM, 1843 [1789], p. 6). Toda a discussão relacionada à mendicância de pessoas capazes de trabalhar, se encaixa neste aspecto de ociosidade desnecessária. Esta é uma das muitas categorias de indigentes presentes na NCC ("falta de vontade para trabalho"), cada uma com seu tratamento específico para fins de justiça e eficiência. Em uma tabela, Bentham resume todas estas categorias, que podem ser listadas em algumas grandes categorias: I. Enfermos da mente (exemplo: insanidade); II. Enfermos do corpo (exemplo: cegos); III. Crianças (exemplo: órfãos); IV. Inabilidade temporária (exemplo: mulheres grávidas); V. Falta de vontade para trabalho (ex.: mendigos); VI. Perda de trabalho (ex.: desempregados); VII. Inabilidade de obter trabalho (ex.: pessoas com má reputação, outro ex.: estrangeiros); e VIII. Perda de propriedade (ex.: indigentes por consequência de um incêndio) (BENTHAM, 1843 [1797], p. 365). Note que, o plano de Bentham é tão ambicioso que, segundo ele, a NCC seria capaz de não só eliminar a indigência na Inglaterra, como também, ter o efeito colateral positivo de eliminar o desemprego (BENTHAM, 1843 [1797], p. 397), reforçar a educação e moralidade das classes mais baixas (BENTHAM, 1843 [1797], p. 419, 424), reduzir a mortalidade infantil (BENTHAM, 1843 [1797], p. 421) e expandir o potencial de homens capazes de servir nas forças armadas (BENTHAM, 1843 [1797], p. 420).

Cada uma destas categorias (de I a VIII) possui subcategorias, com instruções específicas dentro da NCC. Por exemplo, enfermos da mente (como pessoas insanas) e enfermos do corpo (como surdos, cegos ou mutilados), ou mesmo crianças e pessoas com

\footnotetext{
${ }^{69}$ Em sutil discordância (apesar de linguagem similar) com o que escreveria Malthus - que entende o vício e miséria como consequência natural do princípio da população.
} 
inabilidades temporárias, segundo Bentham, deveriam ser colocadas para trabalho na medida em que sua habilidade restrita a atividades específicas torna possível produzir algo. "Inabilidade é apenas relativa", afirma Bentham quanto a estes casos (I, II, III, e IV) que tratam de inabilidade de realizar trabalho (BENTHAM, 1843 [1797], p. 382). As pessoas capazes de realizar quaisquer tipos de trabalhos dentro da NCC (em geral pessoas que estão ali nas categorias V, VI, VII e VIII) deveriam ser colocadas para realizar as atividades que exigem esta versatilidade, e, apenas quando sobrando indigentes nestas categorias, eles poderiam também trabalhar em atividades que aqueles com capacidade limitada realizam. Entre as crianças, Bentham previa a necessidade de um plano de educação, e assim por diante. Cria-se, dessa forma, uma série de regras administrativas quanto ao direcionamento do trabalho de cada categoria afim de melhorar a eficiência e a qualidade de vida dentro da NCC.

Os detalhes mais relevantes para o presente estudo, contudo, estão inseridos em sistemas de incentivo baseados na busca pura pelo prazer e fuga da dor que Bentham espera de todos os homens, incluindo dos trabalhadores dentro da NCC: o princípio do "merecimento primeiro", por exemplo, é especificamente direcionado à categoria de pessoas sem vontade para o trabalho, que sob esta instrução só receberiam auxílio após a realização do trabalho, nunca antes (enquanto as demais classes poderiam receber algum auxílio já se inseridas, voluntariamente ou não, na NCC) (BENTHAM, 1843 [1797], p. 383). Outro princípio pregaria a distribuição de prêmios em dinheiro a alguns poucos trabalhadores que se demonstrassem mais dedicados que outros, afim de incentivar os demais (BENTHAM, 1843 [1797], p. 384).

Ao mesmo tempo, em termos de satisfação do princípio da utilidade, enquanto os benefícios para a sociedade já foram discutidos, os benefícios para os indigentes dentro da NCC seriam também muito relevantes. Bentham destaca, por exemplo, que os confortos dentro da instituição incluiriam "segurança extraordinária em termos de saúde", "higiene", "noites de sono confortáveis", "segurança contra agressões de outros indigentes ou de oficiais", "entretenimento ao menos uma vez por semana", "uma consciência limpa e serviços religiosos", "visitas de parentes e amigos", entre outros benefícios (BENTHAM, 1843 [1797], p. 430-433). Todos estes benefícios, contudo, possuíam um custo: a privação da liberdade dos indigentes para o próprio bem deles e para o bem da sociedade, como veremos. 


\subsubsection{Liberalismo circunstancial e o objetivo de instituições como a NCC}

Como explica Crimmins (1996, p. 751-755), há uma controvérsia significativa quanto a classificação de Bentham como um autor de viés "autoritário" ou "liberal". Como poderiam, estas duas classificações aparentemente opostas (mesmo do ponto de vista de quem às atribuí a Bentham) serem consideradas como características centrais do modo de pensar deste autor? A corrente de comentadores que o classifica como "autoritário" observa a tendência de Bentham em mergulhar nas sanções políticas como se estas fossem uma panaceia ao sofrimento humano - o chamado "panopticotismo" do autor, em referência ao seu projeto de prisão que consumiu uma década de sua vida, se manifesta em muitos pontos de sua obra. Em outras palavras, segundo esta interpretação, apesar de Bentham considerar que em muitos casos o Estado não deva interferir em assuntos privados, este não é de modo algum um princípio de Bentham. Consequentemente, sempre que fosse detectada uma imperfeição em uma sociedade totalmente livre (conduzida pelas ações na ausência de das sanções políticas), era conveniente a sugestão de um esquema elaborado de regras, punições, benefícios, expansão do papel do Estado, afim de criar um ambiente institucional que se conformasse racionalmente com o princípio da utilidade. Não haveria nada de orgânico ou liberal na mentalidade do autor, neste sentido. Já a corrente que argumenta o oposto, a de que Bentham pode sim ser considerado um "liberal", observa exatamente a percepção do autor de que, em geral, a busca pela própria utilidade tenderia a elevar a utilidade geral: "o legislador utilitarista é aquele que valoriza a liberdade porque ela é essencial à felicidade de cada pessoa [...]. Intervenção é necessária quando as précondições à liberdade individual estão ausentes ou prejudicadas" (CRIMMINS, 1996, p. 755). Um bom exemplo seria o caso da necessidade de proteger a vida e a propriedade de cada indivíduo que teme por sua segurança, expandindo a liberdade do indivíduo protegido, às custas da liberdade do ofensor. A restrição de liberdade de um indigente, que inevitavelmente causa males para sociedade, poderia ser justificada de modo similar. Estas visões conflitantes surgem de uma diferença de interpretação quanto ao papel das instituições públicas: enquanto é verdade que o princípio que guia Bentham é unicamente o princípio da utilidade, e, portanto, ele está disposto a sacrificar liberdades individuais em um sentido ex-ante à implementação de uma política, em geral, as consequências desse sacrifício para o todo da sociedade é um aumento de liberdades (ex-post). Ainda que indivíduos específicos tenham suas liberdades limitadas ou completamente eliminadas, a maioria dos indivíduos na sociedade tendem a se sentir mais livres como consequência da legislação. Visto que a liberdade individual expande as possibilidades 
de buscar prazeres e evitar dores de todos os tipos, no agregado, a sociedade está em uma condição melhor através da restrição da liberdade de alguns indivíduos específicos que, se livres, reduziriam a liberdade dos demais.

Como isso se traduz para o tema de caridade e Lei dos pobres? Bentham entende que limitar liberdades de "indigentes" se encaixa no caso em que a sociedade como um todo sai ganhando. Ao contrário de autores mais liberais que restringem as limitações de liberdades à criminosos e outros poucos casos excepcionais (ex.: prisioneiros de guerra), Bentham não vê, a princípio, a necessidade de limitar de modo tão estreito as classes de indivíduos sob os quais a privação da liberdade se adequa aos interesses agregados. A liberdade é um meio, potencialmente descartável, e não um princípio moral.

Não há tampouco necessidade de que o tipo de prazer que compense as restrições à liberdade dos indigentes seja conectado a um aumento da liberdade da sociedade. Em casos extremos, mesmo se o resultado final fosse uma redução da liberdade e esta fosse compensada por prazeres completamente alheios à liberdade de outros, Bentham aprovaria da mesma forma (afinal os prazeres indiretamente decorrentes da liberdade não seriam superiores nem inferiores a quaisquer outros). Por exemplo, se os meros prazeres estéticos da remoção de indigentes fossem suficientes para compensar as dores relacionadas à restrição da liberdade deles, a política já seria adequada. Se os prazeres conectados aos lucros da NCC compensassem estas dores, a instituição já deveria ser considerada um ganho moral. Em sua concepção da NCC era claro esta atitude: "os interesses dos indigentes eram consistentemente sacrificados por lucros à Companhia" (LIBERMAN, 1985, p. 212).

Nem todos seus interesses eram sacrificados, contudo. Como já foi discutido, a privação da liberdade dos indigentes era uma dor necessária para o funcionamento do sistema como um todo. Teoricamente, os tipos de indigentes presentes na NCC por força da lei (e não por vontade própria) teriam ali uma boa qualidade de vida, a despeito de seus desejos de liberdade.

Dessa forma, apesar da percepção geral de que as concepções de Bentham quanto aos indigentes possa ser interpretada como "autoritária", é muito discutível se a condição dos indigentes era objetivamente pior sob o sistema proposto se comparada a condição de miséria sob as então prevalentes Leis dos Pobres. Certamente não era assim que Bentham entendia seu projeto, para ele, o objetivo seria que nenhum indigente dentro da NCC estivesse em condição pior do que qualquer indigente fora dela (HIMMELFARB, 1970, p. 94). Alguns comentadores, como Taylor (1982), concordam com esta tese geral de Bentham. Isto é, compreendido o funcionamento da NCC, seria possível afirmar que haveria sim uma melhoria da qualidade de 
vida dos indigentes, citando uma série de especificidades que são facilmente ignoradas devido ao rigor que acompanha o sistema de auxílio:

Certainly it was to be a rigorous system of relief; but it was to be humane, fairly and impartially administered, a uniform system of relief, and it was to include a large number of undoubtedly beneficial services to the poor and underprivileged; such as banks, inexpensive accommodation for those in search of work, means of transmitting money, refuge for wives in distress, saving banks, a means of informing the unemployed of employment opportunities. As such it represents a signal step forward over existing means of dealing with the indigent (TAYLOR, 1982, p. 309)

Podemos resumir, o argumento moral para o estabelecimento da NCC como totalmente fundamentado no princípio da utilidade: tanto os indigentes, como o resto da sociedade, teriam seus prazeres expandidos e dores reduzidas, no agregado. Considerações sobre tipos específicos de prazeres e dores (considerações morais como liberdade ou igualdade) não vêm ao mérito.

Em suma, a NCC é uma verdadeira utopia como bem observou Himmelfarb (1970), embora, o perspectiva de trabalhos forçados e privação de liberdade não soe como um plano utópico - como a autora argumenta, longe de poder ser considerado um plano "progressista" (no sentido de buscar reformas de caráter mais liberal ou mais igualitário, no contexto político do período), a NCC poderia ser considerada "regressiva" em muitos aspectos: atitudes mais similares ao século XVII em relação aos direitos de indivíduos livres, bem como traços mercantilistas são facilmente identificáveis (HIMMELFARB, 1970, p. 170).

As propostas de Bentham foram entendidas por muitos como "cruéis", tanto que os aspectos negativos vieram a se associar a seu nome, enquanto o lado polarmente oposto, o lado humano, crítico da casa de trabalho, viria a ser associado a Dickens (STOKES, 2001, p. 711). Este projeto, a "cruel" NCC e suas casas de trabalho, era a grande ideia de Bentham para revolucionar a Inglaterra de acordo com seu princípio da utilidade e sua concepção de natureza humana. Tudo isso, segundo ele, poderia ser realizado através de uma grande abertura de capital, e mantido anualmente pelo trabalho dos internados na NCC somado ao subsídio anual que o governo já gastava com a Lei dos Pobres (HIMMELFARB, 1970, p. 83), bem como o recebimento de recursos de caridade privada (BENTHAM, 1843 [1797], p. 428).

O plano de Bentham, é claro, fracassou. Embora aspectos específicos de suas ideias tivessem repercussão na reforma de 1834 da Lei dos Pobres, como a abolição do outdoor relief, que levaria a 10\% da população da Inglaterra às casas de trabalho (HIMMELFARB, 1970, p. 125), os milhares detalhes que teoricamente fariam de sua utopia uma realidade nunca foram implementados. 


\subsection{O legado de Bentham para à "utilidade geral"}

Há um motivo claro para Bentham ser lembrado atualmente como um filósofo, e não como um grande homem de negócios ou engenheiro de prisões, e nem mesmo como o "filantropo dos filantropos", que sua auto descrição sugere que é como ele gostaria de ser lembrado (HIMMELFARB, 1970, p. 125). Em sua busca pela implementação de seu Panopticon, e sua ainda mais delirante NCC, Bentham procurou a aprovação da Inglaterra e do mundo, desejando um poder absoluto sobre seus próprios prisioneiros, a quem Bentham supostamente seria um grande pai (BADER, 1975, p. 253). Ele imaginava que conseguiria tudo isso por meio do apoio do governo, que o frustrou primeiro quanto à construção do Panopticon bloqueada por interesses privados que corrompiam o interesse público (DINWIDDY, 1989, p. 8), e posteriormente devido à recusa de governos de toda a Europa e até mesmo dos recente independentes Estados Unidos de implementar seus códigos legislativos (DINWIDDY, 1989, p. 11-16). Muitos líderes de destaque admiravam suas ideias, mas nenhum as implementou realmente. O desgosto de Bentham pelo sistema político, em particular o sistema inglês foi se alimentando a cada frustração, e pouco a pouco seu radicalismo político foi se tornando evidente. Segundo Baden, a sua NCC é a expressão máxima de sua reação utópica e autoritária a um mundo que não o aceitava:

Bentham sought a world whose passions he found uncongenial. He sought the approbation of a world which mocked him. He sought power over a world which abused him (BADER, 1975, p. 254).

Não parecia que Bentham entendesse que seu grande legado já estava estabelecido em tinta e papel em seus escritos teóricos, que não eram necessárias grandes edificações e manifestações palpáveis e perfeitas de suas ideias. Mal sabia ele que, seu princípio da utilidade e sua visão de natureza humana influenciariam por mais de um século a visão dominante da ciência econômica, com muitas consequências práticas que superam até o mais utópico de seus planos. 


\section{BREVE COMPARAÇÕES ENTRE SMITH, MALTHUS E BENTHAM}

Embora algumas observações quanto às semelhanças e contrastes entre os autores já tenham sido realizadas ao tratar dos principais temas abordados no trabalho, certos paralelos merecem maior destaque, sendo brevemente abordados neste capítulo. As comparações foram separadas em quatro categorias principais: quanto à natureza humana; quanto à moralidade $\mathrm{e}$ questões normativas; quanto à oferta e demanda de caridade voluntária; e quanto ao papel do Estado no auxílio aos pobres. Cada um destes temas centrais à dissertação possui pontos em que os autores estão em concordância ou em conflito, frequentemente revelando como suas visões levam a conclusões diferenciadas para o tratamento da questão do auxílio e caridade na Inglaterra.

\subsection{Quanto à natureza humana}

Como já foi mencionado anteriormente, um ponto que tanto Smith, Malthus e Bentham compartilham, é a visão de que existe de fato uma "natureza humana", isto é, elementos inatos no comportamento e psicologia do homem. Há, entretanto, diferenças quanto a caracterização dessa natureza, bem como a sua flexibilidade e variabilidade, isto é, sua possibilidade de mudança e as diferenças naturais entre diferentes indivíduos. Uma comparação muito relevante que pode ser destacada neste sentido é a percepção muito semelhante de Smith e de Malthus quanto ao fenômeno do autocomando - percebemos que tanto para Smith como para Malthus, existem paixões naturais ao homem que o incitam a praticar vícios, e, para ambos, é possível que o homem venha a superar estas paixões por mera força de vontade. No caso de Smith, esse autocomando permitiria a realização plena das três demais virtudes (prudência, benevolência e justiça), bem como nos auxiliaria a simpatizar e obter a simpatia do próximo. Já em Malthus, este autocomando (ainda que o autor não utilize esta expressão), se manifesta principalmente através do "freio moral", cujo a principal expressão é o controle dos instintos sexuais do homem. Esta preocupação de Malthus, contudo, já estava presente em Smith, que chega a citar como exemplos a "amável virtude da castidade" e "frugalidade" (SMITH, p. 239, 1984 [1759]). Isto é, enquanto a descrição da natureza humana de Malthus é mais específica, focada nos 
aspectos de sobrevivência e reprodução do homem, a descrição da natureza humana em Smith é mais ampla, e contém muito da análise que viria a ser realizada por Malthus, ainda que não se concentre nas consequências destes aspectos. Não é sem razão que, na WN, Smith já descreve a dinâmica oscilatória dos salários resultante do princípio da população que Malthus elaboraria posteriormente (SMITH, 1979 [1776], p. 98), ou seja, Smith já possuía consciência dos efeitos econômicos desta tendência inerente ao homem de se reproduzir em condições de abundância material, uma vez que o autocomando é raramente suficiente para frear tal processo.

O aspecto do "conforto material" é outro ponto de semelhança entre Smith e Malthus. Isto é, a ausência de dificuldades pode gerar uma condição em que não há necessidade de desenvolver um comportamento virtuoso. Para Malthus, a Lei dos Pobres gerava esta ilusão de conforto na forma de uma garantia de condições materiais mínimas, levando à indolência e despreocupação no controle de impulsos sexuais (MALTHUS, 1826, Livro III, p. 87-88). Para Smith, não só a riqueza poderia originar uma corrupção de sentimentos morais, como seria justamente através de situações adversas que o indivíduo poderia adquirir seu autocomando. Por exemplo, para Smith, uma experiência de guerra auxilia no controle do medo (SMITH, p. 239, 1984 [1759]).

Todos estes aspectos de semelhança na natureza humana que convergem entre Malthus e Smith podem ser resumidos na ideia de que embora a natureza humana imponha ao homem paixões que se manifestam na forma de vícios de comportamento, e, embora estas paixões sejam muito fortes (especialmente para Malthus), há, no próprio homem a capacidade de superar tais paixões, sem incorrer em vícios. É a noção de responsabilidade individual, que tanto para Smith como para Malthus pode ser impulsionada pela educação em sua forma apropriada.

Esta noção de responsabilidade individual é pouco presente em Bentham. Pela própria descrição de natureza humana presente na obra do autor, o homem invariavelmente seguirá aquilo que lhe parece trazer mais prazer (e menos dor). Sua sensibilidade a prazeres e dores de diferentes tipos, em diferentes contextos, bem como sua capacidade de avalia-los, depende, no momento de cada ação, de uma série de circunstâncias fora de seu controle. O arbítrio é menor de certa forma no sistema de Bentham, ainda que muitos dos determinantes dos motivos para ação não sejam naturais, mas sim institucionais. Se um indivíduo decidir por não realizar um ato de caridade que beneficiaria substancialmente pessoas merecedoras e em necessidade de auxílio, não faz muito sentido culpa-lo - em circunstâncias idênticas (incluindo as circunstâncias que determinam a natureza particular de cada indivíduo) e com motivos idênticos, qualquer um agiria da mesma forma: maximizando prazer e minimizando dor, gerando o mesmo resultado. Assim, não cabe ao indivíduo "superar suas paixões" e "agir de 
modo virtuoso", como Smith e Malthus desejam. Para Bentham, superar a regra de buscar prazer e evitar dor é impossível, independentemente de que sistema moral se leve em conta para definição de "virtudes". É esta mentalidade que levará Bentham a definir instituições como o Estado como responsáveis à maximização da utilidade geral, e não o indivíduo (que deve ser "manipulado" por tais instituições). Note que não é adequada a comum preconcepção de que um papel maior de instituições indica um determinismo menor no comportamento humano. Smith e Malthus, ambos, são mais céticos em relação ao papel das instituições que Bentham, ainda assim, são eles que veem no próprio homem a capacidade de escolher um comportamento prudente, benevolente, justo (usando as virtudes de Smith) - por meio do autocomando. Bentham, por sua vez, parece restringir o homem ao comportamento que busca ser incessantemente concentrado na prudência. A descrição da natureza humana para Bentham é ampla, como a de Smith, mas enquanto em Smith a simpatia é o princípio geral que estrutura o comportamento humano em sociedade, para Bentham é a busca do próprio prazer e fuga da dor. Enquanto as dores e prazeres dos outros são os condicionantes da ação humana em Smith, as dores e prazeres próprios são os condicionantes da ação humana em Bentham.

Seria incorreto, contudo, imaginar que os sistemas de natureza humana de Smith e de Bentham são em absoluto incompatíveis. Embora partam de premissas distintas que levam a resultados distintos, ambos acabam por incluir tanto a simpatia como o autointeresse. O autointeresse, em especial o autointeresse material, para Smith, se manifesta como uma consequência da simpatia, da busca pela admiração alheia. A simpatia, para Bentham, se manifesta como uma consequência do autointeresse, mais especificamente, um indivíduo só leva em conta seus sentimentos simpáticos devido ao prazer e dor que o ocasionam. Assim, em muitos contextos, as conclusões quanto à ação humana poderiam ser semelhantes, visto que ambos elementos estão presentes na psicologia apresentada pelos dois autores.

\subsection{Quanto à moralidade e questões normativas}

Há, novamente, maior convergência entre Smith e Malthus em questões morais, do que entre Bentham e estes. Isto é, provavelmente, consequência da própria concepção de natureza humana e o papel da responsabilidade individual. Há, ainda, uma semelhança adicional: enquanto Smith (na TMS) e Malthus têm em mente uma ordem natural divina, perfeita, 
Bentham apresenta o papel da religião apenas como um motivador da ação humana (através da sanção religiosa).

Pode-se esquematizar cada uma das visões morais da seguinte forma: Smith (na TMS) não vê defeito no todo da ordem natural, incluindo as desigualdades de todas as ordens (de classe social, econômica, etc.). Tão perfeita seria a ordem natural que, livre de restrições, a pobreza extrema seria muito reduzida e mesmo as pessoas pobres viveriam bem, a despeito de seu desejo de enriquecer. Cada um possui papel em camadas desiguais da sociedade - errado seria cometer injustiças (como utilizar a força do Estado contra os mais ricos) para tentar corrigir o que já é perfeito. De certa forma, para Smith, o grosso do que é o comportamento moral ideal está dentro do próprio indivíduo, podendo ser resumido através das grandes virtudes (prudência, benevolência, justiça e autocomando) - não se limitando à justiça, que é a virtude compartilhada pelo indivíduo e pelo Estado. É verdade que, na WN, esta visão se torna mais flexível e algumas imperfeições na ordem natural são admitidas.

Malthus, compartilha a visão de perfectibilidade da ordem natural de Smith, mas de forma mais explícita indica os mecanismos pelos quais esta ordem, estabelecida por Deus, ajuda o homem, quando este age erroneamente. O sofrimento humano é um sinal, um modo de ensinar que as escolhas do homem ou da sociedade como um todo se contrapõem a vontade de Deus. A utilidade, é uma ferramenta para encontrar a vontade de Deus, um sinal que a expõe.

Assim, é esperado que quando se trata do tema da benevolência como uma solução total para a questão da pobreza, ambos rejeitem a ideia de uma benevolência universal, isto é, que se preocupa excessivamente com todos os seres do mundo sem priorizar aqueles mais próximos. Ela é considerada potencialmente negligente e insensata, uma vez que pode tornar insuficiente o exercício da benevolência direcionada àqueles mais próximos (que dificilmente serão auxiliados por outras pessoas distantes) ou mais merecedores, e, ao mesmo tempo, demonstra uma falta de fé na capacidade de Deus de cuidar da felicidade do universo como um todo ${ }^{70}$.

Para Bentham, o oposto faz mais sentido. O princípio da utilidade é sua régua moral absoluta, incluindo todos os membros de uma comunidade (ou, dependendo do ponto de vista adotado, do mundo). A conclusão em relação à condição humana é, portanto, simples: é necessário reduzir dores e expandir o prazer no mundo. Embora em princípio isto não implique

\footnotetext{
${ }^{70} \mathrm{O}$ seguinte trecho torna este modo de pensar explícito:

"The administration of the great system of the universe, however, the care of the universal happiness of all rational and sensible beings, is the business of God and not of man. To man is allotted a much humbler department, but one much more suitable to the weakness of his powers, and to the narrowness of his comprehension; the care of his own happiness, of that of his family, his friends, his country" (SMITH, 1984 [1759], p. 237).
} 
em uma visão mais igualitária, na prática (devido a utilidade marginal decrescente da renda), uma distribuição equilibrada de recursos econômicos tenderia a elevar a utilidade geral. Ademais, seria uma obrigação moral do legislador (cujo o papel é legislar em acordo com o princípio da utilidade) de buscar arranjos institucionais que atuem sim de modo universal. A utilidade, não é uma ferramenta (como em Malthus), mas sim um objetivo moral final.

Vale destacar outros pontos significantes de divergência entre Bentham e Smith: para Smith ao julgar uma ação humana, ela deve ser considerada tanto do ponto de vista de suas causas (apropriada vs. inapropriada), como do ponto de vista de suas consequências (mérito vs. demérito). O melhor que um indivíduo pode fazer para julgar é buscar dentro de si um "espectador imparcial", uma mistura da visão da comunidade com uma visão divinamente inspirada daquilo que é certo ou errado. Já para Bentham, julga-se uma ação alheia meramente pelas suas consequências - não pelas suas causas (que não afetam o princípio da utilidade diretamente), e julga-se em um sentido prático, isto é, deve-se saber que cada indivíduo (longe de consultar um espectador imparcial) agirá de forma a maximizar o próprio prazer e minimizar a própria dor, e, assim, o julgamento adequado é aquele que torne compatível esta tendência inata com o princípio da utilidade.

Curiosamente, é nesse ponto relacionado ao modo que se julga uma ação humana (moralmente) que há alguma convergência entre Malthus e Bentham, uma das poucas dentro dos temas tratados. Malthus também é, na prática, um "utilitarista", ou ainda, um "consequencialista". Se Malthus pouco mencionasse a conexão de suas doutrinas econômicas e sociais com suas crenças religiosas, sua posição moral seria praticamente idêntica a um utilitarismo puro. Isto é, embora o objetivo moral de Malthus seja religioso (relacionado à vontade de Deus), é através da utilidade que ele o realiza, e, dessa forma, conclui de modo semelhante a Bentham que, aquilo que tende a elevar a utilidade geral é algo bom, enquanto aquilo que tende reduzir a utilidade é algo ruim.

\subsection{Quanto à oferta e demanda de caridade voluntária}

Para Smith, existem enormes obstáculos à simpatia para com o pobre. Consequentemente, há uma restrição significativa da oferta de caridade, levando em conta a TMS. Ao mesmo tempo a demanda de caridade é progressivamente menor, se levada em conta a expansão da prosperidade em uma sociedade comercial, descrita na WN. A oferta e demanda 
de caridade, seriam, assim, ambas pequenas - não há razão para preocupação, não há grande desequilíbrio dadas as premissas nos sistemas de Smith. O que é desejável, contudo, é que seja exercida a virtude da benevolência de modo apropriado $^{71}$, embora não seja uma necessidade (como é a justiça).

Já para Malthus, a demanda de caridade é, e provavelmente sempre será, enorme - como consequência direta do princípio da população, a busca pela sobrevivência e reprodução sempre geram uma enorme necessidade de recursos econômicos por parte de uma massa de miseráveis. O único modo pelo qual esta demanda poderia ser reduzida seria através do freio moral - ainda assim, há ceticismo quanto a adoção plena desta virtude, o homem é uma criatura caída, imperfeita, ainda que a ordem natural que o cerque seja perfeita. A oferta de caridade, por sua vez, é limitada, e é bom que ela seja limitada. Isto é, é bom que a caridade não seja realizada de modo extenso, indiscriminado, pois os mecanismos corretores que a ordem natural impõe ao homem, através do sofrimento, poderiam ser prejudicados. A oferta de caridade, portanto, deve ser muito elogiada, mas apenas quando direcionada àqueles que realmente estão prontos para levar uma vida virtuosa. A caridade indiscriminada poderia gerar mais mal do que bem para um indivíduo que ainda não aprendeu a agir de acordo com a vontade de Deus.

Bentham compartilha a visão de Malthus que a oferta de caridade é pequena em relação a demanda. Isto seria, contudo, consequência direta da falta de interesse próprio na caridade voluntária, se comparado ao enorme interesse de receber caridade na condição de indigente. Ao contrário de Malthus, Bentham não considera esta situação aceitável. Segue diretamente de sua visão moral baseada no princípio da utilidade que algo deve ser feito para eliminar a condição de indigência, para o bem tanto da sociedade como um todo, como dos indigentes em particular.

O resumo destas visões de oferta e demanda de caridade voluntária pode ser compreendido através da seguinte tabela:

\footnotetext{
${ }^{71}$ É interessante notar que, como em Malthus, há uma noção de benevolência "apropriada" (no caso de Malthus "discriminada") e "inapropriada". De fato, ao tratar especificamente de paixões que são diretamente conectadas à benevolência ou a união dos homens, como a "humanidade, generosidade, afeção natural, amizade e estima" Smith afirma, tal como Malthus, que estas podem sim ser excessivas, isto é, o autocomando sobre as mesmas pode ser insuficiente (SMITH, p. 243, 1984 [1759]) - caracterizando imprudência por parte de quem realiza o exagero de generosidade. Porém, ao contrário de Malthus, não há preocupação com possíveis efeitos nocivos à sociedade ou ao receptor da benevolência excessiva, o prejudicado seria unicamente o próprio doador. E pode também ser o caso destas paixões generosas serem defeituosas, o que caracteriza uma insensibilidade e ausência das virtudes de benevolentes.
} 
Tabela 2 - Comparação da oferta e demanda de caridade entre os autores

\begin{tabular}{|c|c|c|c|}
\hline $\begin{array}{c}\text { Tabela } \\
\text { comparativa }\end{array}$ & $\begin{array}{c}\text { Oferta de } \\
\text { Caridade }\end{array}$ & $\begin{array}{c}\text { Demanda de } \\
\text { Caridade }\end{array}$ & $\begin{array}{c}\text { Esta situação é } \\
\text { aceitável? }\end{array}$ \\
\hline Smith & Pequena & Pequena & Sim \\
\hline Malthus & Pequena & Grande & Sim \\
\hline Bentham & Pequena & Grande & Não \\
\hline
\end{tabular}

\subsection{Quanto ao papel do Estado no auxílio aos pobres}

Para Smith (na TMS) e Malthus, a caridade é necessariamente privada, voluntária. As razões para isso são distintas, contudo. Smith utiliza um argumento baseado na essência da virtude da benevolência - que sua realização é apropriada, via de regra, quando voluntária. É apenas na presença de um mal positivo que a presença da força se justificaria, e a ausência de benevolência (por ser mera ausência) não causa nenhum mal positivo ${ }^{72}$. Já para Malthus, a benevolência precisa ser voluntária por razões utilitaristas: a presença do Estado gera distorções nos sinais que a natureza fornece ao homem, isto é, prejudica a capacidade do pobre de corrigir seus vícios, pois o coloca em uma situação mais confortável, e evita que perceba que é necessário aumentar seus esforços no trabalho e no controle de seus instintos. É importante notar, contudo, que mesmo o argumento de Smith contra a Settlement Laws é essencialmente utilitarista. Isto é, Smith está ali argumentando de um ponto de vista econômico - no formato descentralizado, a Lei dos Pobres estaria prejudicando a mobilidade de trabalho. Não há preocupação expressa com o auxílio propriamente dito ou com a oferta e demanda de caridade.

Uma das razões que Malthus destaca como um motivo para que a caridade deva ser necessariamente voluntária é o prazer que o próprio doador sente ao realiza-la, ausente quando o Estado toma para si este papel, um argumento utilitarista (como de esperado na teoria de Malthus). Curiosamente, é justamente a partir deste mesmo ponto que Bentham irá argumentar que o Estado, de alguma forma, tem responsabilidade em assumir a questão da caridade - afinal, se é meramente o prazer de realizar caridade (prazer simpático) o principal motivador para ela, sendo este prazer é tão fraco se comparado com os demais, é certo que a oferta de caridade será insuficiente para satisfazer o princípio da utilidade. Para Bentham, contudo, o Estado teria o

72 A exceção a benevolência voluntária seriam os casos em que a benevolência não ser realizada seria necessariamente inapropriado (como no caso de um pai não sustentar seus filhos quando crianças). 
papel fundamental de estabelecer a NCC, mas não de administrá-la. Para além disso, a NCC teoricamente expandiria as possibilidades de caridade privada (e intensificaria os prazeres de simpatia ao direcioná-la de forma eficiente). O papel do Estado seria o estabelecimento e legislação da NCC, bem como subsídio para cobrir a diferença entre oferta e demanda de caridade. Fica evidente, contudo, que enquanto o papel do Estado em termos de redução da miséria, em Smith e Malthus, é muito limitado (ajudando apenas indiretamente através de educação ou justiça), já o papel do Estado na questão da indigência para Bentham é fundamental (mais amplo que apenas a educação e justiça), interferindo diretamente na oferta de auxílio aos pobres afim de eliminar a indigência em toda a Inglaterra. 


\section{CONSIDERAÇÕES FINAIS}

Ao longo do trabalho foi possível explorar temas que parecem mais amplos do que a questão específica da "caridade" nos três autores escolhidos. As bases do comportamento e moralidade do homem, sob os pontos de vista de Smith, Malthus e Bentham, fundamentam as conclusões relativas à realização de atos benevolentes direcionados à mitigação da pobreza extrema. Ademais, a visão de natureza humana de cada autor informa não só questões relacionadas à caridade privada, mas também questões relacionadas às responsabilidades de auxílio exercido por parte governo - uma discussão frequentemente contextualizada pelo ambiente institucional do período, marcado pelas Leis dos Pobres e suas aparentes consequências.

Inicialmente, no capítulo primeiro, introduzimos o tema explicitando a importância destes conceitos - a concepção de natureza humana de cada autor, e a importância do contexto histórico, incluindo a presença das Leis dos Pobres.

No segundo capítulo, exploramos as ideias de Smith a partir do fenômeno da simpatia - apresentado na sua Theory of Moral Sentiments. E notamos que, o ato de caridade, depende de um longo caminho com grandes obstáculos, isto é, não é fácil simpatizar com aqueles que mais necessitam de auxílio. Segundo Smith, a simpatia tende a ocorrer mais facilmente por meio de paixões positivas, sendo que o sofrimento causado pela miséria tende mais a afastar o observador do que convidá-lo a um sentimento de compaixão genuína. Entretanto, Smith não é "pessimista" neste sentido. A virtude da benevolência, mesmo direcionada àqueles que não apelam as propensões simpáticas do observador, pode ser realizada através do exercício do autocomando: no caso, por meio da realização de um esforço para controlar as paixões negativas que levam ao afastamento daqueles que mais sofrem, seria possível enfim tentar compreender a condição alheia. Por parte daquele que necessita da caridade, o autocomando também é uma virtude essencial, pois é mais fácil que um observador venha a simpatizar com seu sofrimento se este for expressado de modo controlado, estóico, tornando mais fácil a compreensão de quem se busca a simpatia. Além disso, mesmo que os indivíduos falhem na virtude da benevolência, há pouco com o que se preocupar do ponto de vista de Smith. Afinal, em uma sociedade comercial, há uma tendência clara à redução da pobreza extrema, através do crescimento econômico que se espalha até as mais baixas camadas da população. O papel do Estado, neste contexto, é limitado - as Leis dos Pobres não seriam uma questão essencial, e atos de benevolência, como a caridade, deveriam ser essencialmente voluntários. 
No terceiro capítulo, tratamos da visão de mundo de Malthus, que em seu Essay on Population é caracterizada pela primazia dos instintos naturais de sobrevivência e reprodução do homem, o que levaria, em princípio, qualquer tentativa de redução da miséria por meio de redistribuição de riquezas ao fracasso: o resultado seria apenas o aumento populacional e a disseminação da pobreza. Haveria uma exceção a esta regra, que é o desenvolvimento do "freio moral" no indivíduo - a capacidade de controlar seus instintos mais básicos, adicionando assim uma forma virtuosa de controle preventivo ao crescimento populacional. Este ponto de vista leva a uma atitude cuidadosa quanto ao exercício da caridade - haveria a possibilidade de que a caridade, quando exercida de modo indiscriminado, pudesse levar a uma piora da condição humana, uma redução da utilidade, muitas vezes do próprio indivíduo que a recebe se este não possuir a fortitude mental para utilizar os recursos de modo cuidadoso. Por esta razão, Malthus recomenda que a caridade deva ser realizada de modo seletivo, priorizando indivíduos que tenham desenvolvido "freio moral", ou ainda, indivíduos que se encontram em condição de necessidade por infortúnios fora de seu controle e não por responsabilidade própria. Quanto ao papel do Estado no auxílio aos pobres, Malthus é completamente cético - o caráter compulsório da ação do governo prejudica o ato caridoso, e "rouba" dos potenciais doadores a alegria de exercer o ato caridoso ao assumir esta responsabilidade na esfera pública. No contexto em que Malthus escreve, as Leis dos Pobres se apresentam como uma política falha, sendo um exemplo perfeito de como a distribuição indiscriminada de auxílio econômico é uma política desastrosa, que leva ao crescimento descontrolado da população pobre por não levar em conta elementos básicos da natureza humana, e, portanto, precisavam ser abolidas gradualmente. A eliminação completa da miséria, por meio de esquemas públicos ou caridade, seria, no seu entendimento, uma utopia irrealizável na Terra.

No quarto capítulo, estudamos os planos de Bentham para resolver o problema da indigência na Inglaterra, isto é, a condição de insuficiência do indivíduo para manter-se com as condições essenciais para viver. Partindo de uma visão de mundo completamente utilitarista em sua Introduction to the Principles of Morals and Legislation, Bentham expressa a necessidade moral de reduzir o sofrimento humano (e maximizar o prazer), o que o levaria em seus escritos sobre as Leis dos Pobres à inevitável conclusão de que é uma obrigação do legislador agir de forma a eliminar indigência e suas consequências negativas. A caridade privada, por si só, não seria suficiente neste quesito, afinal, os homens, agindo necessariamente sob comando da busca do prazer próprio e fuga da dor própria, calculariam que os benefícios simpáticos de exercer caridade são limitados, em comparação com os confortos materiais diretos de reter a riqueza em suas próprias mãos. Isto não leva, contudo, Bentham a apoiar as Leis dos Pobres, 
considerado um esquema altamente ineficiente que precisaria ser substituído. A proposta do autor é a criação de uma companhia de administração privada, com subsídio público, para abrigar (e capturar à força) todos os indigentes do país, e ali, na National Charity Company, oferecer as condições de vida adequadas e aproveitar do trabalho compulsório de seus detentos. O plano de Bentham nunca foi realizado, mas suas ideias utilitaristas foram bastante influentes, e a conclusão de que a indigência é um mal que deve ser combatido por conta das dores que esta condição ocasiona (tanto ao indigente quanto à sociedade), bem como sua visão de comportamento dirigido pelo prazer e dor, foram significantes ao desenvolvimento do pensamento econômico.

Por fim, no quinto capítulo fizemos rápidas comparações entre os três autores nas esferas da suas respectivas visões de natureza humana, moralidade, oferta e demanda de caridade, e papel do Estado no auxílio aos pobres.

Com isso, espera-se que tenha sido possível chamar um pouco mais de atenção ao tema da caridade dentro do pensamento econômico. Não é um tema que pode ser tratado sem vínculos com disciplinas externas à economia, mas ainda assim é um tema que merece mais atenção por ser um fenômeno com importantes consequências econômicas. Espera-se também que, este trabalho sirva de exemplo de como a ideia de natureza humana, de uma psicologia inata ao homem, mais complexa que a mera busca pelo autointeresse, pode afetar profundamente conclusões dentro da esfera da economia política. As obras de Smith, Bentham e Malthus são exemplos distantes da importância desta ideia de natureza humana, que merece ser resgatada pela história do pensamento para o estudo de muitos outros temas além da caridade. 


\section{REFERÊNCIAS BIBLIOGRÁFICAS}

BADER, W. C. Jeremy Bentham: Businessman or "Philanthropist"? Albion: A Quarterly Journal Concerned with British Studies. v. 7. n. 3. 1975.

BATES, Alfred. The Drama: Its History, Literature and Influence on Civilization. Athenian Edition. 1903.

BAUM, Sandy. Poverty, Inequality, and the Role of Government: What Would Adam Smith Say? Eastern Economic Journal, v. 18, n. 2. 1992.

BENTHAM, Jeremy. Writings On The Poor Laws. The Collected Works of Jeremy Bentham, Volume II. Ed. Michael Quinn, Claredon Press, Oxford. 2001 [1797].

BENTHAM, Jeremy; Tracts on Poor Laws and Pauper Management. The Works of Jeremy Bentham, Volume Eight. 1843 [1797].

BENTHAM, Jeremy. An Introduction to the Principles of Morals and Legislation. The Works of Jeremy Bentham, Volume One Ed. Russell \& Russell, New York. 1843 [1843 [1789]].

BENTHAM, Jeremy. Pannomial Fragments. The Works of Jeremy Bentham, Volume Three Ed. Russell \& Russell, New York. 1843 [1831].

BEN-ZE'EV, Aaron. Envy and Inequality. The Journal of Philosophy. v. 89. n. 11. p. 551581. 1992.

BIANCHI, Ana Maria; A Pré-História da Economia: De Maquiavel a Adam Smith. Ed. Hucitec. São Paulo. 1988.

BIRCH, T. D.; An Analysis of Adam Smith's Theory of Charity and the Problems of the Poor. Eastern Economic Journal, v. 24, n. 1. 1998.

BOWEN, Ezra. Malthus, a Revaluation. The Scientific Monthly. V. 30, n. 5. P. 465-471. 1930.

BOWLER, P.J. Malthus, Darwin, and the Concept of Struggle. Journal of the History of Ideas. V. 37, n. 4, p. 631-650. 1976.

CAMPBELL, W.F; Adam Smith's Theory of Justice, Prudence, and Beneficence. Adam Smith: Critical Assessments, Volume I. Ed. John Cunningham Wood, Routledge, 1996.

COASE, R.H. Adam Smith's View of Man. Selected Papers, n.50. Graduate School of Business, The University of Chicago. 1976.

CREMASCHI, Sergio. Malthus's War on Poverty as Moral Reform. CRIS Bulletin. v. 2, p. 43-54. 2013.

CREMASCHI, Sergio. Utilitarism and Malthus's Virtue Ethics, Respectable, virtuous and happy. Routledge, Nova York. 2014. 
CRIMMINS, J.E. Contending Interpretations of Bentham's Utilitarianism. Canadian Journal of Political Science. v. 29. n. 4. 1996.

DARWIN, Charles. The Descent of Man, and selection in relation to sex. Princeton University Press. 1981 [1871].

DIAS. M.C.L.C. A ampliação do espaço da moral no utilitarismo de John Stuart Mill: uma comparação com a moral do utilitarismo de Benhtam. Tese de Doutorado. Faculdade de Filosofia, Letras e Ciências Humanas da Universidade de São Paulo. 2011.

DINWIDDY, John. Benthan. Past Masters. Oxford University Press. 1989.

ELTON, G.R. An Early Tudor Poor Law. The Economic History Review. New Series, v. 6, n. 1, p. 53-67. 1953.

FIESER, James. Moral Philosophy through the ages. Mayfield Publishing Company. 2001.

FISHLOW, Albert. T.R. Malthus and the English Poor Laws. Social Science. V. 33, n. 1. p. 45-51. 1958.

FISHMAN, J. J. Governmental Encouragement of Philanthropy in a Time of Crisis: 1601 - The Past as Prologue? An Examination of the Poor Laws and the Statute of Charitable Uses. Presented to the Nonprofit Forum. 2004.

FORSBERG, Ake. Nassau Senior, the Whig leaders' counsellor in the age of laissez-faire. History of Ideas. 2006.

GARNETT, Rob. Against Benevolence: Adam Smith's Economy of Care. Texas Christian University Summer Intitute. 2015.

GILBERT, G. Adam Smith on the Nature and Causes of Poverty. Review of Social Economics, v. LV, n. 3, Fall. 1997.

HANLEY, R.P.; Adam Smith and the Character of Virtue. Cambridge University Press, Cambridge. 2009.

HARDIN, Garrett. The Feast of Malthus, Living within limits. The Social Contract, Spring, 1998. Disponível em: <http://www.thesocialcontract.com/pdf/eight-three/hardin.pdf>. Acesso em: 15 ago 2016.

HEILBRONER, R.L. The Essential Adam Smith. Ed. Norton \& Company, New York. 1986.

HERBERT, Sandra. Darwin, Malthus, and Selection. Journal of the History of Biology. V. 4, n.1. p. 209-217. 1971.

HIMMELFARB, Gertrude. Bentham's Utopia: The National Charity Company. Journal of British Studies. v. 10. n. 1. 1970. 
HUZEL, J. P. The Demographic Impact of the Old Poor Law: More Reflections on Malthus. Malthus and His Time, p. 40-59. 1986.

JENSEN, H.E. The Development of T.R. Malthus's Institutionalist Approach to the Cure of Poverty: From Punishment of the Poor to Investment in Their Human Capital. Review of Social Economy. V. 57, n. 4. P. 450-467.

KHALIL, E.L. Adam Smith and Three Theories of Altruism. Louvain Economic Review. v. 67. n. 4. p. 421-435. 2001.

KHALIL, E.L. Introduction: Smith the hedgehog. The Adam Smith Review, v.2. The International Adam Smith Society. 2006.

LAMB, R. B. Adam Smith's System: Sympathy not Self-Interest. Journal of the History of Ideas. v. 35. n. 4. p. 671-682. 1974.

LEVIN, S.M. Malthus and the Idea of Progress. Journal of the History of Ideas. V. 27, n.1. p. $92-108.1966$.

LIEBERMAN, David. From Bentham to Benthanism. The Historical Journal. v. 28. n. 1. 1985.

MAITLAND, Ian. Virtuous Markets: "The Market as School of the Virtues". Business Ethics Quarterly.v.7.n. 1.p. 17-31. 1997.

MALThUS, Thomas R. An Essay on the Principle of Population. Sixth Edition. London, 1826.

MALTHUS, Thomas R. An Essay on the Principle of Population. First Edition, Electronic Scholarly Publishing Project. 1998 [1798].

PALMER, Robert C. Selling the Church: the English Parish in Law, Commerce, and Religion, 1350-1550. The University of North Carolina Press. 2002.

PETERSEN. William. Malthus: The Reactionary Reformer. The American Scholar. V. 59. N. 2. p. 275-282. 1990.

QUIGLEY, William P. Five Hundred Years of English Poor Laws, 1349-1834: Regulating the Working and Nonworking Poor. 1996. Disponível em: <https://www.uakron.edu/dotAsset/726694.pdf>. Acesso em: 01 jun 2016.

RAPHAEL, D.D. The Impartial Spectator: Adam Smith's Moral Philosophy. Oxford University Press. 2007.

RAPHAEL, D.D. MACFIE, A.L. Introduction. The Theory of Moral Sentiments. Oxford University Press, Liberty Fund, Indianapolis. 1984.

REISMAN, D.A. Adam Smith on Market and State. Journal of Institutional and Theoretical Economics. v. 154. n. 2. p. 357-383. 1998. 
SHIN, J. M. Adam Smith's Impartial Spectator: His Reliance on Societal Values, Limits in Inspiring Altruism, and Application in Today's Context. Vanderbilt Undergraduate Research Journal. v. 10. 2015.

SILBER, Jacques. Malthus' Preconditions to Moral Restraint and Modern Population Economics. Genius. V. 42. N. 3/4. p. 13-21. 1986.

SIMONS, R.B. T.R. Malhtus on British Society. Journal of the History of Ideas. V. 16, n. 1. 1955.

SMITH, Adam. An Inquiry into the Nature and Cause of the Wealth of Nations, Volume I. Oxford University Press, Liberty Classics, Indianapolis. 1979 [1776].

SMITH, Adam. An Inquiry into the Nature and Cause of the Wealth of Nations, Volume II. Oxford University Press, Liberty Classics, Indianapolis. 1979 [1776].

SMITH, Adam. The Theory of Moral Sentiments. Oxford University Press, Liberty Fund, Indianapolis. 1984 [1759].

SMITH, Adam. Lectures on Jurisprudence. Oxford University Press, Liberty Fund, Indianapolis. 1978 [1762].

SEN, Amartya; Adam Smith and the contemporary world. Erasmus Journal for Philosophy and Economics, v. 3, Issue 1, p. 50-67. Harvard University. 2010.

SOWELL, Thomas. Malthus and the Utilitarians. The Canadian Journal of Economics and Political Science. V. 28. N. 2. P. 268-274. 1962.

STOKES, P. M. Bentham, Dickens, and the Uses of the Workhouse. Studies in English Literature, 1500-1900. v. 41. n. 4. 2001.

TAYLOR, Brian. A Note in Response to Itzkin's "Bentham's Chrestomathia: Utilitarian Legacy to English Education". Journal of the History of Ideas. v. 43. n. 2. 1982.

VINER, Jacob. Adam Smith and Laissez Faire. Adam Smith: Critical Assessments, Volume I. Ed. John Cunningham Wood, Routledge. 1996.

VINT, John. Harriet Martineau, Nassau Senior and Poor Law Reform. Department of Accounting, Finance and Economics, Manchester Metropolitan University, Business School. 2013. Disponível em: http://www.business.uwa.edu.au/_data/assets/pdf_file/0008/2326256/John-Vint.pdf>. Acesso em: 23 mar 2016.

WINCH, Donald. Malthus. Past Masters. 1987.

WINCH, Donald; Poverty and Pauperism: From Smith to Malthus. Kumamoto Journal of Economics, v.3, n. 4, p.1-15. 1998.

YOUNG, Robert M. Malthus and the Evolutionists: The Common Context of Bilogical and Social Theory. Past \& Present, n. 43, p. 109-145. Maio, 1969. 
